\title{
Osobnostně
}

sociální

rozvoj

studentů

— budoucích

učitelů

Michal

Svoboda

Eva

Gažáková 


\section{Osobnostně sociální rozvoj studentů - budoucích učitelů}

Michal Svoboda, Eva Gažáková

https://doi.org/10.24132/ZCU.2020.09440

Rok vydání: 2020 

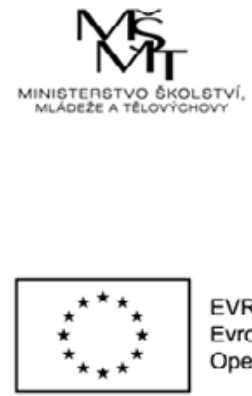

EVROPSKÁ UNIE

Evropské strukturálni a investični fondy

Operačni program Výzkum, vývoj a vzdēlávání

Zvyšování kvality pregraduálního vzdělávání na Fakultě pedagogické ZČU

Číslo projektu:

CZ.02.3.68/0.0/0.0/16_038/0006677 


\section{OBSAH}

ÚVOD 1

1. VYMEZENí OSOBNOSTNÍHO A SOCIÁlNíHO ROZVOJE JAKOŽTO DŮLEŽITÉ SLOŽKY VZDĚLÁVÁNÍ BUDOUCÍCH UČITELŮ NA FPE ZČU V PLZNI

1.1 Vymezení osobnostního a sociálního rozvoje ............. 3

1.2 Osobnostní a sociální rozvoj v profesní prípravě učitelů na FPE ZČU v Plzni 6

1.2.1 Popis výchozího stavu a teoretických východisek 6

1.2.2 Popis současného stavu a inovace metod ............18

1.2.3 Aktivizující výukové metody využívané v kurzech osobnostně sociálního rozvoje

1.2.4 Specifické herní aktivity/techniky využívané v kurzech osobnostně sociálního rozvoje..........40 40

\section{DRAMATICKÉ HRY V KURZECH OSOBNOSTNĚ} SOCIÁLNÍHO ROZVOJE NA FPE ZČU V PLZNI............. 90

2.1 Vymezení dramatické výchovy......................... 90

2.2 Metoda strukturovaného dramatu..................... 95 


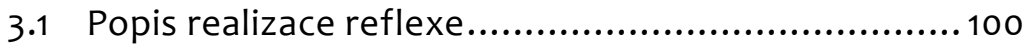

3.2 Zobecňující výsledky z reflexí ..........................101

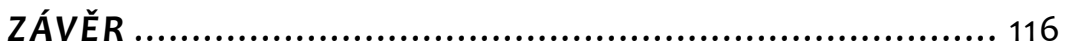

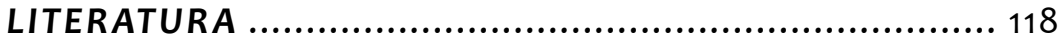



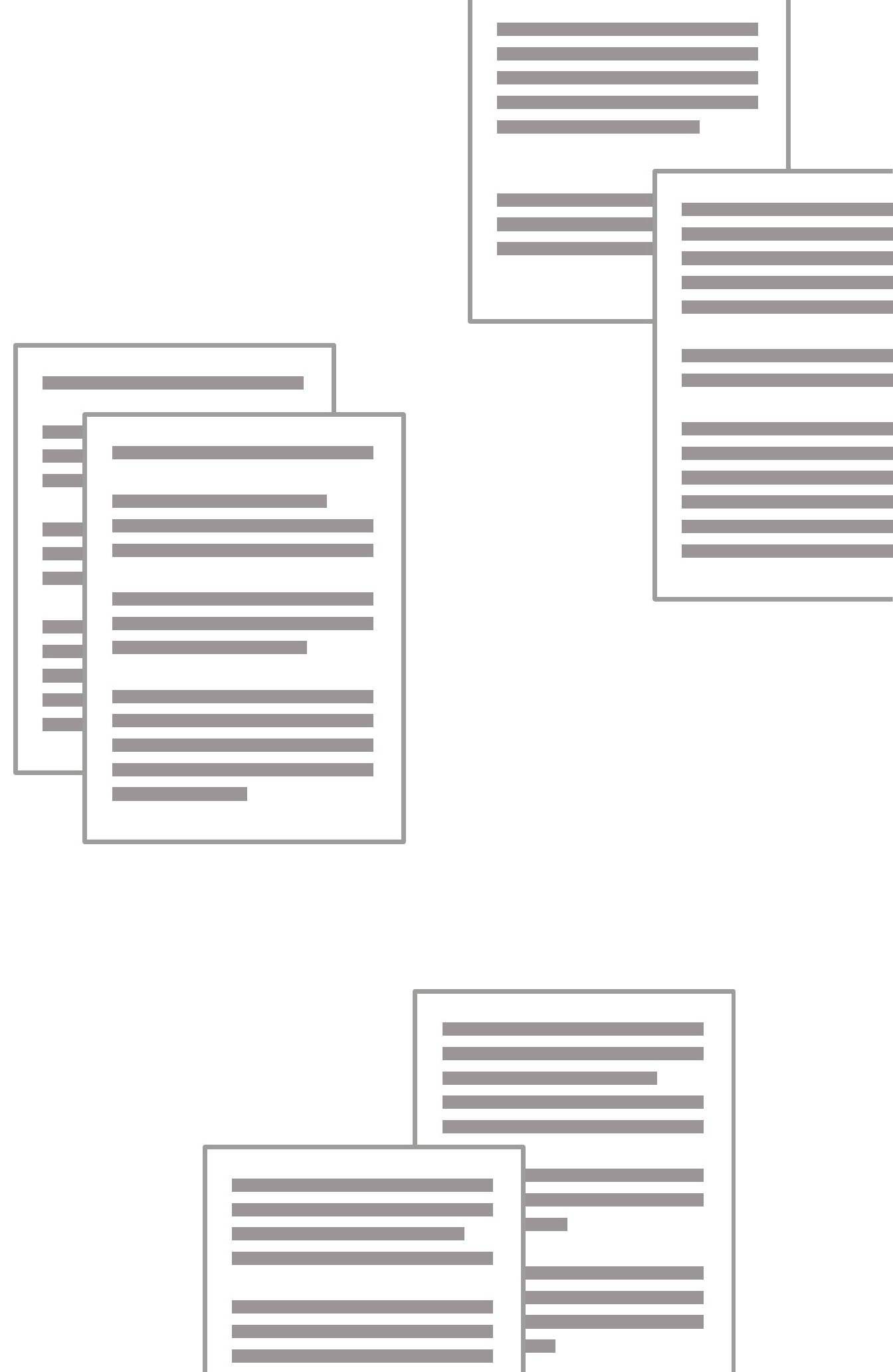


\section{ÚVOD}

Milý čtenáři,

dostává se Ti do ruky publikace, jež se trochu ohlíží do historie vývoje předmětu osobnostní a sociální rozvoj (dále OSR) na plzeňské pedagogické fakultě, detailně vymezuje obor OSR a jeho východiska a hlavně se snaží předložit přehlednou metodiku se souborem aktivit, metod a technik, jimiž lze u účastníků procesu stimulovat jejich osobnostní a sociální růst.

Publikace popisuje systém osobnostního a sociálního rozvoje na Fakultě pedagogické (dále FPE) ZČU v Plzni v oborech se zaměřením na př́pravu budoucích učitelů. Na základě postřehů z pedagogické praxe je zřejmé, že pro plnohodnotné naplňování výchovně vzdělávacího procesu je důležitá určitá úroveň osobnostních a sociálních kompetencí učitele. Učitel se setkává s různorodými předem jednoznačně nepredikovatelnými pedagogickými situacemi vyžadujícími pedagogovo flexibilní sociální reagování. Z tohoto důvodu byla do řešení projektu Zvyšování kvality pregraduálního vzdělávání na FPE ZČU zařazena oblast posilující rozvoj osobnosti studentů jakožto budoucích učitelů.

V metodice je nejprve nastíněn sytém osobnostního a sociálního rozvoje na plzeňské FPE před realizací projektu. Dále jsou v něm popsaná teoretická východiska, z nichž se při koncipování zvyšování kvality osobnostního a sociálního rozvoje studentů vycházelo. Za stěžejní krok v rámci realizovaného projektu je možné považovat 
vytvoření a následně ověření nového předmětu Osobnostní a sociální rozvoj 2 (KPG/OSR2). Ve dvou samostatných kapitolách jsou představeny metodika kurzu a konkrétní využité aktivity včetně ukázky strukturovaného dramatu. $\vee$ poslední kapitole jsou uvedeny postřehy studentů získané po skončení kurzů z jejich písemných reflexí.

Předkládaná publikace je určena nejen pro vzdělavatele budoucích učitelů, ale zároveň pro širokou odbornou veřejnost, jež se o problematiku osobnostního a sociálního rozvoje zajímá. 


\section{1.}

\section{VYMEZENÍ OSOBNOSTNIIHO A SOCIÁLNÍHO ROZVOJE JAKOŽTO DŮLEŽITÉ SLOŽKY VZDĚLÁVÁNÍ BUDOUCÍCH UČITELŮ NA FPE ZČU V PLZNI}

\subsection{Vymezení osobnostního a sociálního rozvoje}

Jedním z důležitých záměrů ve vzdělávání budoucích učitelů je rozvoj jejich osobnostních a sociálních kompetencí. Tyto kompetence jsou důležité nejen pro běžný život, ale zároveň jsou součástí odborných kompetencí potřebných pro výkon učitelské profese. Obecně můžeme říci, že v pedagogickém procesu osobnostního a sociálního rozvoje se jedná o př́znivý růst osobnostních a sociálních kompetencí jedince, které jsou potřebné pro jeho optimální způsob jednání v různých situacích, do kterých se v průběhu svého života a výkonu učitelské profese dostává. $V$ rámci tohoto pojetí můžeme osobnostní a sociální rozvoj definovat dle Lazarové a Knotové: „jedná se o snahu pomoci člověku dosáhnout lepšího bytí, ke zlepšení kvality jeho života." (In Koláŕ, 2008, s. 38) Obdobně na vymezení osobnostního a sociálního rozvoje pohliží Prod’homme. Ten uvádí, že se osobnostní a sociální rozvoj zaměřuje na ,využití osobního 
potenciálu, progresivní rozvoj talentu a specifických individuálních schopností" (In Kolář, 2008, s. 39).

Na základě výše uvedených definic můžeme $v$ několika bodech vystihnout charakteristiku pedagogického procesu osobnostního a sociálního rozvoje:

$\rightarrow$ Osobnostní a sociální rozvoj je záměrný a cílevědomý pedagogický proces, jehož cílem je příznivý rozvoj (růst) všech složek tvořících osobnostní a sociální kompetenci studenta, tzn. vědomostí, dovedností, postojů a hodnot potřebných pro plnohodnotný osobní život jedince a jeho optimální orientaci v mezilidských vztazích a profesních situacích.

$\rightarrow$ Osobnostní a sociální rozvoj je integrální součást celkového výchovného působení na osobnost studenta. $Z$ pohledu plnohodnotného naplnění jeho významu v oblasti kultivace osobnosti budoucího pedagoga se využívá prvků postmoderního myšlení. Tyto prvky odmítají výchovné ideje vycházející převážně z osvícenství (např. Herbart, Humboldt, Fichte, Lindner), v nichž je výchova vnímána jako autoritářská, striktně vedoucí ke stanoveným společenským cílům bez ohledu na individuální potřeby a zájmy vychovávaného. $V$ souladu s účely osobnostního a sociálního rozvoje $v$ duchu postmoderního myšlení definuje výchovu Pelikán, který uvádí, že „výchova je cílevědomým a záměrným vytvářením a ovlivňováním podmínek umožňujících optimální rozvoj každého jedince v souladu s individuálními dispozicemi stimulujícími jeho vlastní snahu stát se autentickou, vnitřně integrovanou a socializovanou osobností“ (1995, s. 36). V pedagogickém působení, jehož cílem je zdárný rozvoj osobnostních a sociálních kompetencí budoucího učitele, nelze opomenout všechny atributy, které jsou součástí 
humanisticky - postmoderně orientované výchovy. Z tohoto důvodu má osobnostní a sociální rozvoj v praktické rovině podobu výchovného působení na jedince. $V$ evropských kurikulárních dokumentech se můžeme setkat s názvem „Personal and social education (P.S.E.),“v českých dokumentech s názvy: „Osobnostní a sociální výchova“, „Dramatická výchova“ apod.

$\rightarrow$ Pedagogický proces osobnostního a sociálního rozvoje se uskutečňuje ve studijních skupinách v počtu cca 12-20 členů. V podmínkách pedagogických fakult zachování takto přiměřeně početných skupin může být často problémem, protože do studijních oborů jsou přijímány větší počty uchazečů. Dělit velkou studijní skupinu na menší skupiny bývá z rozvrhového hlediska obtížné, především u studentů kombinovaných forem studia.

$\rightarrow$ Podstata pedagogického procesu osobnostního a sociálního rozvoje spočívá v sebepoznání jedince (poznání sebe sama, svých povahových stránek, kladů a nedostatků, a osobnostních vlastností, uvědomění si podstaty, př́čin, motivů svého jednání v různorodých životních situacích) a rozvoji jedince (optimální růst - vývoj osobnostních vlastností s akcentem na vlastní individuální dispozice). Sebepoznání a rozvoj jedince jsou v pedagogickém procesu osobnostního a sociálního rozvoje nerozlučně spjaty, navzájem se podmiňují, organicky prolínají a spojují.

$\rightarrow$ Pedagogický proces osobnostního a sociálního rozvoje je obsahově zaměřený na témata vztahující se k osobnosti člověka ( $k$ sobě), k jednání člověka v mezilidských vztazích ( $k$ druhým), k profesním situacím, pedagogickým kompetencím (k profesi) apod. Je důležité zdůraznit, že témata v osobnostním a sociálním rozvoji se vzájemně prolínají, nelze je úplně, kategoricky dělit do uvedených oblastí. 


\subsection{Osobnostní a sociální rozvoj v profesní přípravě učitelů na FPE ZČU v PIzni}

\subsubsection{Popis výchozího stavu a teoretických východisek}

Osobnostně sociální rozvoj v podobě samostatného kurzu má na FPE ZČU v Plzni dlouhou historii. Hned začátkem 90. let. 20. stol. $v$ rámci polistopadových reforem učitelského vzdělávání v oblasti pedagogicko-psychologické př́ípravy byl do studijních plánů zařazen povinný kurz osobnostně sociální rozvoj. V průběhu let docházelo k profilování obsahu předmětu podle individuálních potřeb studentů a charakteru studovaných oborů (učitelství pro mateřské školy, učitelství pro ZŠ/SŠ). Zároveň se zkvalitňovaly i prostorové podmínky pro výuku takto specificky pojatého předmětu. Na katedře pedagogiky vznikla odborná učebna pro výuku osobnostního a sociálního rozvoje - Ateliér dramatické výchovy. Hned od začátku výuky povinného předmětu osobnostně sociálního rozvoje byl do studijních plánů zařazen i výběrový předmět sociálně psychologický výcvik. Velkým počinem pro komplexní rozvoj osobnosti studentů učitelství byl vznik kurzů se zaměřením na dramatickou výchovu. Tyto předměty byly povinné či výběrové podle charakteru studovaného oboru, tvořily jednotný celek a byly strukturovány do certifikátového - prohlubujícího studia Dramatická výchova.

$\rightarrow \quad$ Inspirativním zdrojem pro koncipování teoretické podstaty předmětu osobnostně sociální rozvoj na FPE v Plzni jsou tzv. teoretické systémy osobnostního a sociálního rozvoje. Ve výuce tohoto 
předmětu se nejvíce používají teoretické a metodické koncepce osobnostní a sociální výchovy, dramatické výchovy, sociálně psychologického výcviku, globální výchovy, etické výchovy a multikulturní výchovy. Pro úplnost a objasnění hlavní podstaty osobnostně sociálního rozvoje v př́ípravě učitelů na FPE v Plzni jednotlivé koncepce $v$ krátkosti popíšeme.

\section{Osobnostní a sociální výchova}

Tento systém se zaměřuje na celkový rozvoj osobnosti jedince ve všech jeho oblastech individuálního a společenského života. Valenta prímo uvádí, že „Specifikou osobnostní a sociální výchovy je, že se učivem stává sám žák-student, stává se jím konkrétní žákovská skupina-skupina studentů a stávají se jím více či méně běžné situace každodenního života." (2000, s. 91) Valenta v dalších definicích konkretizuje osobnostní a sociální výchovu. Píše, že se jedná „o praktickou disciplínu zabývající se rozvojem kličových životních dovedností či životních kompetencí... jejím smyslem je pomáhat každému žákovi hledat vlastní cestu k životní spokojenosti založené na dobrých vztazích k sobě samému i k dalším lidem a světu." (2006, s. 45) Můžeme rríci, že obsahem osobnostní a sociální výchovy jsou témata, která se př́mo dotýkají celé osobnosti studenta. Tzn. jeho osobnostního rozvoje (rozvoj schopností poznávání, seberegulace a sebeorganizace, psychohygiena, kreativita), jeho sociálního rozvoje (poznávání lidí, mezilidské vztahy, komunikace, kooperace a kompetice) a jeho rozvoje morálního (řešení problémů a rozhodovací dovednosti, hodnoty, postoje a praktická etika). Svým obsahovým pojetím naplňuje všechna témata pedagogického procesu osobnostního a sociálního rozvoje: k sobě, k druhým, 
k profesi. Širokému pojetí osobnostní a sociální výchovy v rozvoji osobnosti jedince nasvědčuje i různorodá škála metod, her, cvičení a učebních forem používaných v pedagogické praxi jako jsou např.: aktivizující - zkušeností metody, psací metody, relaxační metody, problémové metody, kooperativní učební situace, modelové situace, rolové a simulační hry.

\section{Dramatická výchova}

V současné době spočívá význam oboru dramatická výchova pro obor osobnostní a sociální rozvoj dle mnohých autorů (např. Kotaátková, 1998; Machková, 1998, 2007; Valenta 1999; Marušák, Králová, \& Rodriguezová, 2008) v tom, že se jedná o „učení zkušeností, tj. jednáním, osobním, nezprostředkováním poznáváním sociálních vztahů a dějů, přesahující aktuální reálnou praxi zúčastněného jedince. Je založena na prozkoumávání, poznávání a chápání mezilidských vztahů, situací a vnitřního života lidí současnosti i minulosti, reálných i fantazií vytvořených. Toto prozkoumávání a poznávání se děje ve fiktivní situaci prostřednictvím hry v roli, dramatického jednání v situaci. Je to proces, který může, ale nemusí vyústit v produkt představení. Cíle dramatické výchovy jsou pedagogické, prostředky dramatické." (Machková, 1998, s. 32) Z této definice je patrné, že dramatická výchova je založena na vzájemném jednání mezi účastníky a z něho plynoucím ději. Děj má povahu dramatického jednání, jež vyžaduje vysokou aktivitu účastníků, jejich osobní zaujatost a angažovanost na nějakém dění, ale i očekávání plynoucí z konfliktu, zápletky či obtíže, kterou je třeba rozřešit či překonat. Dramatické jednání se odehrává v prostředí fikce, tj. v prostředí smluveného fiktivního světa, jenž je tvořen skutečnými osobami 
nebo věcmi. Machková fikci v dramatické výchově vysvětluje slovy: „Je to představování, dělání jako, jako kdyby, modelování komunikace materiálu komunikace samé, pokus nebo model „,v životní velikosti.“ (1998, s. 33) Dějově dramatické jednání ve fiktivním světě ztvárňují účastníci v podobě hry v roli, tj. postupem, při němž se člověk stává někým jiným nebo něčím jiným, vstupuje do pozice někoho jiného. Rolová hra má v dramatické výchově mnoho podob. Mnozí autoři (např. Valenta, 1997, 2008; Machková, 1998, 1999; Marušák, Králová, \& Rodriguezová, 2008) rozlišují rolovou hru dle různých aspektů specifických znaků. V plné rolové hře hráč mluví i tělesně koná, ale dle uvedených autorů může mít rolová hra i limity: omezeno může být slovo (pantomimické aktivity), změněno tempo (zpomalená hra), omezen může být pohyb až do pohybu nulového v případě živých obrazů (i v nich jsou hráči v určité roli, ale nehýbají se; je to obraz, zastavený čas), rolová hra může být vztažena i k aktivitě pouze verbální (hráči píší za postavu dopis, mluví za někoho jiného, nebo prezentují jako v rozhlasové hře jen hlasy). Stejně tak má hra v roli i několik stupňů - od simulace, kdy je hráč sám sebou, ale ve změněných, fiktivních okolnostech (tedy ,,já“ kdybych se dostal do situace, kdybych byl v situaci, kdyby se mi nebo kolem mě něco dělo), přes alteraci, kdy již hráč přebírá cosi z jiné postavy, ovšem bez bližšího určení, na základě jistých schémat (stává se např. blíže a individuálně neurčeným lékařem, otcem, námořníkem) až k charakterizaci, kdy hráč jedná za individuální, konkrétní, jedinečnou postavu (Marušák, Králová, \& Rodriguezová, 2008, s. 12). Dalším zásadním pojmem vztahujícím se k metodám dramatické výchovy je improvizace. Její význam spočívá v tom, že provází rolovou hru studentů v různé míře - může to být plná improvizace, kdy hráč jedná za sebe či postavu v jistých okolnostech zcela nepřipraveně, 
přes částečně připravené improvizace až po propracované krátké dramatické tvary - etudy, v nichž je improvizace stále př́tomna, ale omezena předcházející tvorbou etudy a prípravou hráčů na prezentaci. (Marušák, Králová, \& Rodriguezová, 2008, s. 13) Mezi metody dramatické výchovy patř́ ještě celá řada technik, her, cvičení, které rozvíjejí osobnostní a sociální vlastnosti jedince a zároveň mu umožňují proniknout do podstaty jednotlivých divadelních forem a žánrů.

\section{Sociálně psychologický výcvik}

Sociálně psychologický výcvik můžeme chápat jako systém metod a technik aplikované sociální psychologie, který se v praxi využívá k ovlivňování jednotlivců a skupin. Jeho jednoznačné vymezení není v odborné literatuře jednotné. Na to poukazuje Valenta, když píše „,v dostupné literatuře nenacházíme jednoznačné vymezení systému kratší definice. Většinou je systém implicitně definován na pozadí širších výkladů a jeho funkcích a metodách.“ (1999, s. 19) Uvedený autor poukazuje na možné další názvy, které mohou $\checkmark$ širším pojetí specifikovat sociálně psychologický výcvik jako je např.: „,aktivní sociální učení (hledisko vnitřního procesu učení), interakční pedagogika (hledisko metodického principu a zohlednění vnějšího zásahu), intervenční metody sociální psychologie (hledisko průniku do určitých struktur osobnosti a chování a hledisko proměny a prostředku), trénink sociálního chování (hledisko typu opatření a cíle) atd." (Valenta, 1999, s. 19). Z pohledu cílů, metod a obsahu lze sociálně psychologický výcvik definovat tak, že se jedná o systém, který je založený na osobní prožitkové zkušenosti, ale zároveň je propojený s teoretickými poznatky. Jeho účinnost souvisí s procesy 
sociálního učení, především s interiorizací a exteriorizací. Obsahem výcviku je zdokonalování sociálních dovedností, které se vztahují jak k sobě samému (např. sebepoznání a sebereflexe, rozpoznání a přiměřené pojmenování emocí, autenticita), tak k mezilidským vztahům (empatie, akceptace druhých, otevřené vyjadřování za sebe sama, naslouchání, pochopení stanoviska druhého člověka, tolerování odlišných pohledů, poznávání druhých, mezilidská komunikace, zvládání konfliktů atd.). Sociálně psychologický výcvik vznikl na konci 1. poloviny 20. století jako reakce na nedostatečnou způsobilost člověka v oblasti sociálních dovedností. Hermochová a D. Vaněková (In Komárková, Slaměník, \& Výrost et al., 2001, s. 11-12) uvádějí, že sociálně psychologický výcvik vychází z myšlenky, že sociální dovednosti lze získat a cvičit jen v rámci skupinového výcviku. Byly proto organizovány programy zaměřené na rozvoj jedince, na odhalení jeho kapacit, jež neměl kde rozvinout. Tyto skupiny, které se označovaly jako T-skupiny, vznikaly v podstatě jako laboratorní výcviková metoda, jako propojení výzkumu s aplikací. Byly jednou z forem, jak názorně ukázat, a tím také naučit tomu, co probíhá ve skupině. Smyslem výcviků nebylo zaměřovat se u svých členů na analýzu minulých zážitků (např. zážitky z dětství), ale analyzovat aktuální chování podle pravidel „zde a nyní“. T-skupiny se rozšírily do nejrůznějších oblastí společenské praxe (průmysl, výchova, sociální služby atd.). Jejich cílem bylo zvyšovat sociální kompetence účastníků i efektivitu skupiny. Cíle T-skupiny byly formulovány jako cíle edukativní, nikoli terapeutické. Smyslem bylo dovědět se prostřednictvím vlastních zážitků ve skupině více o sobě samém i o tom, jak se ve skupině chovají druzí a jak toto vlastní a cizí chování ovlivňuje skupinovou dynamiku. Lektor skupiny vedl účastníky k tomu, aby se naučili učit z vlastní zkušenosti 
a zažití jejich vlivu na skupinové dění. Výcvikových skupin rychle přibývalo a začaly se posupně diferencovat nové skupiny, které kladly méně důraz na skupinovou dynamiku a více zdůrazňovaly „já.“ Tento směr byl zachycen především existenciálními a humanistickými psychology. Pod jejich vlivem vzniklo relativně samostatné hnutí skupin setkání - encounterových skupin. Skupiny setkání se vydělily z hnutí T - skupin tím, že více akcentovaly klinický aspekt a více se koncentrovaly na jedince. Specifickým znakem skupin setkání bylo, že většinou nečinily rozdíl mezi osobním růstem a psychoterapií. Cílem byl rozvoj sebeuvědomění jedince, usnadnění osobního rozvoje a seberealizace. Skupiny setkání užívaly široké palety metod, různých forem relaxace, prohloubení sebeuvědomění, zkoumání snů a fantazií, neverbálních aktivit, tance, fyzického kontaktu a meditací. Z celkového pohledu můžeme říci, že všechny typy sociálně psychologického výcviku mají následující základní charakteristiky:

$\rightarrow \quad$ jde o minimalizovaný model společnosti;

$\rightarrow$ pracuje se $v$ nich se skupinovými procesy;

$\rightarrow$ jde o intenzivní, záměrně navozený proces učení;

$\rightarrow$ probíhající proces učení je podporován atmosférou psychologického bezpečí;

$\rightarrow \quad$ je zvýrazněna role členů skupiny oproti roli lektora.

Pro potřeby osobnostního a sociálního rozvoje v př́pravě učitelů je vhodná kombinace obou popisovaných proudů. $V$ kurzech je důležité se zaměřovat na výcvik-trénink konkrétních sociálních dovedností potřebných pro rozvoj profesních kompetencí a zároveň využívat technik, jež mají sebereflektivní charakter a při nichž 
si student uvědomuje jedinečnost vlastní osoby a možnosti svého vnitřního životního směrování.

\section{Globální výchova}

Za další hojně využívaný systém osobnostního a sociálního rozvoje v současném pojetí učitelské přípravy Ize považovat globální výchovu. Globální výchova jako výchovně - vzdělávací směr vzniká v 80. letech 20. století při univerzitě v Yorku. Mnohými autory (např. Pike \& Selby, 1994, 2000; Horká, 2000; Skalková, 2004; Švestková, 2006) je chápaná jako ucelený systém propojující reflexi globálních problémů Země (planetární vědomí), paidocentrismus (důraz na centrální postavení dítěte ve vzdělávacím procesu) a systémovou teorii (důraz na vztahy mezi prvky). Toto propojení se promítá do čtyř dimenzí, ve kterých jsou vystiženy hlavní znalosti, dovednosti a postoje, jež si žáci mají v průběhu vzdělávacího procesu osvojovat:

$\rightarrow$ Prostorová dimenze: rozvíjí porozumění světu v jeho provázanosti a pochopení vzájemné závislosti ( $v$ kontrastu k atomistickému vnímání světa a lineárnímu myšlení). Provázanost světa je spatřována v rovině lokální a globální, v rovině mezilidských vztahů, různých vědních oborů atd. S tím úzce souvisí prožívání pocitů solidarity.

$\rightarrow$ Dimenze problémů: zahrnuje porozumění globálním a lokálním problémům i osobním problémům žáků, jejich vývoji a vzájemné spojitosti. Učí reflexi různých úhlů pohledu na dané problémy, včetně svého vlastního, a jejich respektování. 
$\rightarrow$ Časové dimenze: pomáhá uvědomit si spojitost minulosti, př́tomnosti a budoucnosti - ve světovém dění i vlastním životě. Zaměřuje se na předvídání a tvořivé plánování budoucnosti.

$\rightarrow \quad$ Vnitřní dimenze: jedná se o znalosti, dovednosti a postoje potřebné k tomu, aby se žáci vydali na cestu celoživotního osobního růstu a naplňovali tak odpovědnost vůči sobě a svému okolí (světu). Je přitom důležitý rozvoj jejich sebedůvěry, sebepoznání a vlastní identity, opravdovosti, cílevědomosti a uvědomění důležitosti všestranného rozvoje osobnosti.

Mezi typické prostředky, jež jsou v rámci globální výchovy používány, patří dle autorů (např. Pike \& Selby, 1994, 2000; Švestková, 2006) různé diskusní techniky, simulační hry, hry s rolemi, kritické čtení textu a další. Ve spojitosti s osobnostním růstem jedince, tzn. s dř́ve popsanou „vnitřní dimenzí“, se často používají prostředky se zaměřením na kultivování smyslů a poznávání rytmu těla pomocí metod jako je jóga, tanec, meditace, dechová cvičení či různé další aktivity směřující k pochopení vztahu mezi člověkem a př́rodou.

\section{Etická výchova}

Jedná se o systém dostávající se v poslední době do středu pozornosti v řadě zemí. Jeho význam spočívá v reakci na devalvaci základních principů lidské společnosti projevující se ve zhoršujících se mezilidských vztazích a způsobu života jako je např. nadměrná sobeckost, egoismus, poživačnost, konzum bez hranic apod. $Z$ důvodu oslabení vlivu rodiny a dalších tradičních organizací (např. církve, občanských spolků apod.) na současnou mládež vznikají 
na školách a v mládežnických organizacích programy, které se snaží vykompenzovat deficit v oblasti mravní výchovy. Mezi první autory projektu etické prosociální výchovy patří profesor Robert Roche-Olivar z univerzity v Barceloně. V zámoří byl průkopníkem obdobného projektu - výchova charakteru - profesor Larry Nucci z Michiganské univerzity v Chicagu. Postupem doby - od 80. let 20. stol. - byly tyto projekty ověřovány $v$ mnoha zemích a upravovány na specifické podmínky jejich kultur. Hlavním výchovným těžištěm těchto projektů je rozvoj schopnosti prosociáního, kooperativního chování a projevování citů druhým - rozvoj schopnosti empatie. Mezi hlavní okruhy etické výchovy patří:

$\rightarrow \quad$ Komunikace (pozdrav, otázka, odpověd', poděkování, objasnění, omluva).

$\rightarrow$ Důstojnost lidské osoby (sebepoznávání, sebepřijetí, pozitivní hodnocení sebe - self esteem, poznávání vlastních silných stránek).

$\rightarrow$ Pozitivní hodnocení druhých (pochvala, úcta k druhým, postoj k nemocným a starým lidem).

$\rightarrow \quad$ Kreativita a iniciativa (řešení problémových úloh, rozvoj tvořivosti).

$\rightarrow \quad$ Vyjadřování vlastních citů a jejich usměrňování.

$\rightarrow \quad$ Interpersonální a sociální empatie (vcítění do myšlenek, stanovisek a pocitů druhých nebo jiných sociálních skupin).

$\rightarrow$ Asertivita (zvládání agresivity a soutěživosti, sebeovládání, řešení konfliktů).

$\rightarrow$ Reálné zobrazené vzory (např. literární, mediální).

$\rightarrow$ Prosociální chování v oblasti vztahů (pomoc, darování, dělení se, spolupráce, přátelství).

$\rightarrow$ Empatie. 
$\rightarrow$ Rodina a její role.

$\rightarrow \quad$ Prosociální chování ve veřejném životě (solidarita, sociální problémy, ochrana prírody a její etické aspekty).

$\rightarrow$ Sociální kritika (občanská neposlušnost, násilí).

$\rightarrow$ Komplexní prosociálnost.

Mezi aplikační témata patř́i: vztah v rodině, sexuální etika, etické otázky ekologie, vztah k ekonomickým hodnotám, vztah k práci, vztah k náboženství, vztah k lidem odlišných názorů, vztah k médiím aj. V České republice je etická výchova prezentována, tzn. osvětově i metodicky podporována, občanským sdružením Etické fórum, jehož začátky sahají do roku 1999. Etická výchova nemá své specifické metody a formy. Využívá didaktických prostředků charakteristických i pro jiné systémy osobnostního a sociálního rozvoje, jejichž cílem je naplnění čtyř fází pedagogického procesu: senzibility (žák pochopí smysl, význam určité skutečnosti, tématu, o kterém se hovoří), hodnotové reflexe (žák zevšeobecní, vyvodí podstatné znaky jednotlivých jevů daného tématu), nácviku ve tř́íde (žák experimentuje s určitým druhem chování, nácvikem si osvojuje nové dovednosti) a reálné zkušenosti (žák využívá nově osvojených dovedností v reálném životě - transfer do běžných životních podmínek).

\section{Multikulturní výchova}

Nedílnou součástí systémů osobnostního a sociálního rozvoje je z pohledu současných celospolečenských požadavků multikulturní výchova. Obecným cílem tohoto systému z pohledu osobnostního 
a sociálního rozvoje je naučit studenty učitelských oborů přijímat a navazovat plnohodnotné interakce mezi skupinami lidí s odlišnými sociálními a kulturními znaky. Tento záměr se prolíná do témat jako je např. porozumění a chápání individuálních odlišností mezi lidmi; poznávání a respektování kultur druhých; uvědomování si své vlastní kulturní identity; rozvoj sociálních dovedností pro harmonický vztah s lidmi z rozdílných etnik; způsoby aktivního potírání projevů amorality, intolerance, xenofobie, diskriminace a rasismu aj. Pro naplňování jednotlivých témat se používá celá škála didaktických metod vycházejících z principů aktivního sociálního učení. Multikulturní výchova je v České republice podporována mnohými organizacemi (např. Nadace tolerance, Člověk v tísni, HOST - Hnutí občanské solidarity a tolerance, Nadace Nová škola aj.), které se zabývají jejím obsahovým i metodickým pojetím.

Můžeme říci, že společným jmenovatelem všech popisovaných výchovně-vzdělávacích systémů je kultivace / rozvoj osobnosti, který je ale realizován ve větší či menší míře v kontextu teoretického pojetí, jež je charakteristické pro daný systém. $V$ hodinách osobnostního a sociálního rozvoje na FPE ZČU se jednotlivé systémy doplňují a překrývají. Při nácviku konkrétních kompetencí je možné využívat všech popisovaných systémů podle cílů a upřednostňovaného pojetí. 


\subsubsection{Popis současného stavu a inovace metod}

V rámci projektu Zvyšování kvality pregraduálního vzdělávání na Fakultě pedagogické ZČU v Plzni se inovovala struktura předmětů osobnostně sociálního rozvoje $v$ rámci bakalářského studia ve studijních oborech se zaměřením na vzdělávání. Hlavním těžištěm byla tvorba a ověřování nového předmětu osobnostní a sociální rozvoj 2 (dále OSR2), který svým zaměřením navazuje na povinný předmět osobnostní a sociální rozvoj (dále OSR). Cílem kurzu OSR2 je nabídnout studentům v praktických ukázkách metody a techniky vedoucí k prohloubení rozvoje osobních a sociálních pedagogických kompetencí. Kurz je zaměřen na rozvíjení a prohlubování komunikačních dovedností, sebeuvědomění, rozvoj kreativity, schopnosti koncentrace, smyslového vnímání a sebereflexe. Student si v kontextu se studovanou literaturou v kurzu vyzkouší základní principy činnostního učení a interaktivních metod vzdělávání a ověří si své osobní dispozice pro práci s lidmi, pro úspěšné zapojení do kolektivu, pro prezentování vlastních postojů i pro vedení skupiny. V kurzu jsou využívány aktivizační metody vycházející z principů zážitkové pedagogiky, dramatické výchovy a etické výchovy.

Kurz OSR2 je dotován 30 hodinami prímé výuky a vznikl v reakci na poptávku studentů hledajících na OSR obsahově navazující předmět. Hodinová dotace pro přímou výuku OSR je 26 hod / semestr, přičemž do budoucna bude dokonce pouze 13 hod / sem.

OSR2 tedy navazuje na zkušenosti studentů a dále je prohlubuje a rozvíjí. Účastníci kurzu si kromě zážitkové výuky zkoušejí i vlastní tvorbu lekce osobnostního a sociálního rozvoje, její vedení a reflexi. 


\subsubsection{Aktivizující výukové metody využívané v kurzech osob- nostně sociálního rozvoje}

Významným prostředkem pro rozvoj osobnosti studentů ve vysokoškolské přípravě budoucích učitelů jsou aktivizující vyučovací metody. Jankovcová, Průcha a Koudela vymezují aktivizující výukové metody jako „postupy, které vedou výuku tak, aby se výchovně-vzdělávacích cílů dosahovalo na základě vlastní učební práce studentů, přičemž důraz se klade na myšlení a řešení problémů". (In Maňák \& Švec, 2003, s. 105) Mezi aktivizující vyučovací metody patří: metody diskusní, metody heuristické - řešení problémů, metody situační, metody inscenační a didaktické hry. Jednotlivé vyučovací metody z pohledu jejich významu pro rozvoj osobnosti popíšeme.

\section{Metody diskusní}

Metody diskuse mají řadu variant a modifikací, např. disputace, rozprava, beseda, rokování, výměna názorů. Tyto varianty se vzájemně odlišují svými cíli a způsoby realizace, ale v podstatě jde vždy o komunikaci ve skupině zájemců o určitý problém. Maňák diskusní metodu považuje za ,formu komunikace pedagoga a studenta, při níž si účastníci navzájem vyměňují názory na dané téma, na základě svých znalostí pro svá tvrzení uvádějí argumenty, a tím společně nacházejí řešení daného problému“ (2003, s. 105). Podle mnohých autorů (např. Glöckel, 1991; Kammann, 1991) se na metodu diskusní kladou následující specifické nároky.

$\rightarrow$ Předpokladem účinné diskuse je vhodně zvolené téma, pro účastníky zajímavé, obsahující provokující podněty, rozpory apod. 
$\rightarrow$ Průběh diskuse se ř́dí předem dohodnutými pravidly a probíhá ve fázích (vymezení tématu, prezentace a výměna názorů, argumentace a zdůvodnění tvrzení, shrnutí výsledků diskuse).

$\rightarrow$ Důležitým předpokladem je osobnostně-sociální připravenost (vyzrálost) studentů a jejich předběžný a průběžný výcvik v dovednostech diskutovat, tzn. rozvoj dovedností aktivního zapojení do diskuse, zrakového kontaktu, sledování diskuse a naslouchání jiným, zvládání řečnických technik, jasné a zřetelné řeči, přesné formulování myšlenek, respektování cizích názorů aj.).

$\rightarrow$ Př́prava na diskusi (např. na formu středověké disputace) zahrnuje včasné oznámení tématu, př́pravu argumentů pro a proti, aspoň částečnou znalost problematiky, promyšlení tezí aj.

$\rightarrow \quad$ Je nutné promyslet otevřené a současné pevné rízení diskuse (udělování slova, dodržování časového limitu jednotlivých vystoupení, formulování dílčích závěrů, držení se tématu aj.).

$\rightarrow \quad$ Nezbytné je př́iznivé sociální klima ve skupině (otevřené, tolerantní, povzbudivé atd.).

$\rightarrow$ Diskusi podporuje dobré organizační a prostorové zajištění (kruh, půlkruh, podkova, dostatečně velký prostor aj.).

Předpokladem kvalitní a plnohodnotné diskuse v rámci pedagogického procesu osobnostního a sociálního rozvoje, jež směřuje k podchycení podstaty diskutovaného tématu a rozvoji komunikativních dovedností u všech aktérů, je vhodná formulace otázek. V literatuře (např. Mareš \& Křivohlavý, 1995; Schneiderová \& Schneider, 2004; Kotrba \& Lacina, 2007; Vališová, 2007) můžeme najít následující typy otázek, které naplňují hlavní didaktický smysl diskuse: 
a) Startující otázky - tyto otázky otevírají diskusi, pokládá je většinou sám pedagog, který diskusi v úvodu řídí (např. Co očekáváte od dnešního setkání? Kdo se na dnešní setkání těšil a komu se naopak moc přijít nechtělo? Už jste někdy podobný program absolvovali? aj.).

b) Uzavřené otázky - na tento druh otázek existuje pouze jednoslovná odpověd' typu ANO, NE. Nebo na ně Ize dát stručnou odpověd' (jedno heslo, pojem). V pojetí osobnostního a sociálního rozvoje jsou tyto otázky pokládány pouze výjimečně. Mohou však účastníky podnítit k vyjádření jasného postoje $\mathrm{k}$ danému problému (např. Souhlasíte s tímto návrhem řešení?). Uzavřená otázka je úvodním základem diskusní techniky „Středověká disputace“ (např. Jste pro zavedení trestu smrti? Jste pro eutanázii?).

c) Otevřené otázky - tyto otázky tvoří základ každé diskuse, např. „Panelové diskuse“, „Kruhových rozhovorü“ apod. Jejich cílem je zjistit a zároveň rozvíjet názory, postoje, stanoviska na dané téma či problém (např. Jaká další možná řešení se nabízela? Které sociální dovednosti jsou potřebné pro zvládnutí dané situace? Čeho si nejvíce ceníte u druhých?).

d) Provokativní otázky - jejich význam spočívá v oživení diskuse, podněcování účastníků $\mathrm{k}$ aktivitě a vyprovokování je k hledání nových pohledů (např. Myslíte si, že dokážete přesně vystihnout podstatu daného problému? Tyto argumenty mohou být považovány za povrchní, dokážete vystihnout podstatu toho, o čem zde diskutujeme?). Na druhou stranu musí být tyto otázky vhodně použity, jinak hrozí, že se účastníci uzavřou a nebudou ochotni v diskusi dále pokračovat. 
e) Př́mé otázky - podstata těchto otázek spočívá v tom, že jsou záměrně a cíleně směrovány $\mathrm{k}$ dosažení různých záměrů tazatele. Používají se často k oslovení účastníků, kteří se do diskuse méně zapojují (např. Co si o tom myslí ti, kteří se ještě k danému tématu nevyjádřili?).

f) Doplňující otázky - jedná se o typ otázek, které vyžadují podrobnější odpověd' (např. Souhlasíte s názory a postoji této skupiny? Zkuste více popsat, jak jste to mysleli?). Při jejich použití existuje obvykle více správných odpovědí.

Aj.

V pedagogickém procesu osobnostního a sociálního rozvoje se diskuse může uplatňovat v mnoha variantách, jak je popisují mnozí autoři (např. Clark \& Stark, 1976; Bratská, 1992; Kotrba \& Lacina, 2007). S ohledem na námi sledovanou problematiku se zde vyjádř́me jen k některým:

a) Brainstorming (burza nápadů) - hlavním cílem této formy diskuse je produkce nových myšlenek, hypotéz, které by měly vést $k$ vyřešení daného problému. Brainstorming je založen především na asociativním způsobu myšlení. Klíčový problém, jejž je třeba vyřešit, se musí jednoznačně zformulovat a napsat na dobře viditelné místo. Jednou $z$ dalších důležitých podmínek pro úspěšnou realizaci této metody je zaznamenávání celého průběhu diskuse, zejména všech vyslovených nápadů. Zpracování výsledků brainstromingu probíhá pomocí trí́dění uvedených nápadů podle zvolených kritérií, např. reálné, nereálné, realizovatelné a nerealizovatelné apod. Šubrtová uvádí následující zásady, které je třeba 
pro úspěšnou realizaci této metody dodržovat: zákaz kritizování (platí princip zákazu kritizování, tj. žádný z účastníků nesmí nikoho z diskutujících zesměšnit, zpochybnit cizí myšlenky); rovnost účastníků (všichni účastníci mají stejná práva, nikdo není nadřazen); úplná volnost nápadů (kreativitě, hravosti, bláznivým řešením, netradičním myšlenkovým pochodům se meze nekladou, žádný nápad není považován za nesmyslný); princip kvality před kvantitou (cílem je produkce maximálního množství nápadů, čím více, tím lépe); princip asociace a kombinace (nápady a nová řešení vzniknou především v důsledku asociativního myšlení a vzájemné návaznosti jednotlivých účastníků.); vzájemné ovlivňování účastníků (každý nápad vytvořený pomocí brainstormingu je ovlivňován předchozím řešeními a návrhy); pohodové, klidné prostředí (prostředí je velice důležité a tvoří základ realizace všech diskusních metod). (Z. Šubrtová, 1984, s. 28).

Písemnou obdobou brainstormingu je brainwriting. Využívá se zejména pro odbourávání psychických bariér z diskusních metod. Velice výhodné je využití této metody ve větších skupinách nebo v př́ipadě, že záměrem pedagoga je snížit hluk ve studijní skupině. Základní, nejjednodušší formou brainwritingu je pouhé psaní nápadů na lístečky, které pak studenti připevňují na tabuli pro inspiraci ostatních. Uvedenou metodu je možné využít v různých obměnách podle výukových podmínek a edukačních cílů.

b) Řetězová diskuse - tato metoda se většinou využívá v případech, kdy studenti ještě nemají dostatečné zkušenosti s diskusí. Je vhodná k nácviku základních komunikativních dovedností. Cílem tohoto typu diskuse je nácvik naslouchání druhým, umění formulovat jasně otázky a shrnovat závěry. Pedagog jako první uvede 
téma diskuse. Na jeho výstup navazují studenti. Každý z nich shrne předcházející př́spěvek a vysloví své stanovisko, tím se téma diskuse dále rozvíjí.

c) Panelová diskuse - této metody se účastní studenti a přizvaní odborníci, nebo se samotní studenti stylizují do role odborníků. Diskuse probíhá za zcela neformálních podmínek. Základem dobře vedené panelové diskuse je jasně stanovené téma (přiměřené věku studentů) a dodržování zásad efektivní komunikace. Na začátku diskuse vyjádří každý odborník své stanovisko, což probíhá formou krátkých výstupů či prezentací. Po těchto vystoupení je dán prostor pro diskusi, v níž studenti pokládají odborníkům (nebo svým kolegům, kteří vystupují v roli odborníků) dotazy.

d) Diskuse v malých skupinách - předností diskuse v malých skupinách je možnost všech diskutujících projevit a vyjádřit svůj názor. Tento typ diskuse vyžaduje správné rozdělení členů kolektivu do menších skupin, jež by měly být pokud možno co nejrůznorodější, ne však konfliktní (Kotrba \& Lacina, 2007, s. 115). Za optimální se uvádí sedmičlenné skupiny (Šubrtová, 1984, s. 27). Studenti řeší zadaný problém ve skupinách. Do skupinových diskusí pedagog nezasahuje. Po zpracování skupinového řešení probíhá opět diskuse v plénu, kdy zástupci jednotlivých skupin prezentují a obhajují své závěry přede všemi. Celá diskuse se rekapituluje a vyvozuje se z ní závěr.

e) Hobo metoda (často též uváděná jako metoda „Středověké disputace“) - jedná se o metodu, která je velice náročná na prípravu, a to jak ze strany pedagoga, tak i ze strany diskutujících studentů. Ouroda zdůrazňuje, že se jedná o jednu z mála diskusních metod, která vyžaduje samostatnou studijní př́pravu všech zúčastněných 
před zahájením vlastní diskuse, tzn. všichni musí být připraveni a mít nachystány podpůrné materiály (Ouroda, 2000, s. 118). Jednou z důležitých podmínek efektivní přípravy a následné úspěšné diskuse je jednoznačné naformulovaní otázek s možností odpovědi ANO, či NE. Kotrba a Lacina uvádějí následující formy „Hobo metody" (Kotrba \& Lacina, 2007, s. 118):

1. Všichni studenti řeší jeden problém, který je složitý a nestrukturovaný. Neexistuje na něj jednoznačné řešení. Je nezbytná orientace ve faktech, které budou tvořit argumenty a podklady k diskusi. Ta většinou probíhá ve skupině.

2. Studenti se rozdělí na dvě skupiny, na předkladatele návrhu a oponenty. $\vee$ každé skupině se pak řeší problém, kdy jednotlivé strany konfrontují své názory. $V$ této variantě existují dvě možnosti průběhu:

a) Hledá se kompromis, na který přistoupí obě dvě strany. Písemně zpracovaný závěr se odevzdá učiteli.

b) Jde především o argumentaci, schopnost přesvědčit druhého o svém názoru.

Diskusní skupiny mohou řešit různé problémy (např. Trest smrti ANO, či NE? Povolili byste eutanázii? Jaderná energie naše budoucnost, nebo prokletí? atd.). Po skupinové práci pak následuje diskuse v plénu, ve kterém každá skupina představuje svoje závěry a řešení. Diskuse se uzavírá závěrečnou rozpravou řízenou učitelem-lektorem.

f) Metoda konsenzu - podstatou této diskusní metody je najít shodu, souhlas, jednotný názor mezi všemi členy skupiny na 
problém, jenž je obsahem diskuse. Konsenzus je stav, kdy všichni členové souhlasí s navrženým řešením. Diskuse začíná v malých skupinách. Po nalezení konsenzu v prvotních skupinách se skupiny na sebe nabalují až vznikne jedna velká skupina, ve které se snaží všichni účastníci dojít k jednotnému, souhlasnému závěru. Tato metoda má mnoho variant. $Z$ důvodu časové náročnosti se diskuse může uskutečňovat jen v menší skupině, ostatní členové jsou $v$ roli pozorovatelů, jejich cílem je zrekapitulovat průběh diskuse a navrhnout další možná řešení vedoucí k dosažení konsenzu.

\section{Metody heuristické, řešení problémů}

Tyto metody, jak sám název napovídá, se vztahují ke slovu heuristika. Heuristika (z řec. heuréka = objevil jsem, nalezl jsem) je dle Maňáka „věda zkoumající tvưrčí myšlení, také heuristická činnost, tj. způsob řešení problémư" (Maňák, 2003, s. 113). Problémové úlohy tvoří základ všech aktivizujících metod. V každé se řeší určitý problém, který je pomocí aktivizační metody různě pojat, zpracován a řešen. $V$ současném pojetí pedagogického procesu osobnostního a sociálního rozvoje se význam heuristických metod výrazně posiluje, protože jejich prostřednictvím si studenti osvojují důležité osobnostní a sociální předpoklady, např. samostatné a tvořivé myšlení (vyhledávání, shromažd’ování, třídění a uspořádávání dat, údajů a informací, kladení otázek a tvorba hypotéz, řešení rozporů a problémů atd.); posilování seberegulačních vlastností - vůle, schopnosti zvládat zatížení; rozvíjení sociálních dovedností potřebných pro práci ve skupině apod. Řešení problémových úloh se odehrává v několika postupných fázích: 
$\rightarrow \quad$ Vytvoření problémové situace: vyvolává potřebu řešit problém, problémovou situaci navozuje většinou pedagog prostřednictvím instrukce nebo písemného materiálu. Problémovou situaci mohou ovšem podnítit i spontánně studenti.

$\rightarrow$ Analýza problémové situace: spočívá v poznání známých a neznámých prvků a závislosti mezi nimi. Ve výuce probíhá analýza většinou studiem a čtením zadání, v podmínkách pedagogického procesu osobnostního a sociálního rozvoje diskusí, rozpravou, kladením otázek apod.

$\rightarrow$ Formulace problému: představuje vrchol předchozí fáze, studenti pochopí podstatu problémové úlohy, dokážou nejčastěji ve formě otázky vyjádřit, o co v dané úloze jde.

$\rightarrow$ Řešení problému: studenti hledají vazby mezi svými zkušenostmi, znalostmi a vnějšími podmínkami. Hledá se řešení daného problému, odpověd' na otázku. To může být provedeno metodou pokus - omyl, nebo na základě intuice, minulé zkušenosti, prŕípadně rozumové analýzy.

$\rightarrow$ Verifikace řešení: $v$ této fázi se ověřuje správnost řešení $s$ cílovými hodnotami a podmínkami řešení. Návrh a realizace řešení se porovnává se zadáním a s dalšími navrženými postupy směřujícími k dosažení stanoveného cíle.

$\rightarrow$ Zobecnění postupu řešení problému: zobecnění provádí pedagog společně se studenty nejčastěji prostřednictvím reflexe. Cílem této fáze je zobecnění způsobu řešení tak, aby bylo použitelné i pro jiné prípady. Po této fázi následuje procvičování a upevňování nových poznatků a dovedností. 
Problémových úloh existuje celá řada a dají se rozlišovat na základě mnoha hledisek. Podle způsobu řešení se nejčastěji dělí na skupinové řešení problému a individuální řešení problému (Maňák \& Švec, 2003; Kotrba \& Lacina, 2007). V pedagogickém procesu osobnostního a sociálního rozvoje jsou většinou upřednostňovány problémové úlohy, jež jsou založeny na skupinovém způsobu řešení. Základním modelem této formy je takové uspořádání výukových činností, kdy studenti řeší stejný problém ve skupinách, následuje jednání v plénu, kde zástupci jednotlivých skupin prezentují své řešení. Neexistuje striktní nařízení postupu práce. Skupinové řešení problémů má mnoho podob, záleží zejména na charakteru zadané úlohy. $V$ některých případech jsou vstupní informace sděleny pouze vedoucím skupinek, kteří se po instruktáži vrátí do svých pracovních skupin, informují ostatní a společně s nimi řeší problém. Na závěr referují zástupci skupin o výsledcích skupinové práce. Sleduje se přitom nejen kvalita řešení, ale i vliv zkreslených nebo neúplných informací na řešení problému. $V$ jiných úlohách začíná řešit problém celá skupina najednou, v průběhu se pak její členové rozdělí do menších skupin, závěrečné fáze se opět odehrávají v plénu.

\section{Metody situační}

Situační metody dle Maňáka rozšiřují řešení relativně vyhraněných a identifikovaných problémů o novou dimenzi, nebot' ,se vztahují na širší zázemí problému, na reálné případy ze života, které představují specifické, obtižné jevy vyvolávající potřebu vypořádat se s nimi, vyžadující angažované úsilí a rozhodování" (Maňák, 2003, s. 119). Podstata situačních metod spočívá v řešení problémového případu, jenž 
odráží nějakou reálnou událost, zobrazuje určitý komplex vztahů a okolností, je výrazem střetu různých zájmů. Výše zmiňovaný autor dále uvádí, že z pedagogického pohledu se za problémový př́pad považuje metodicky zpracovaný materiál reflektující reálnou problémovou situaci, jejíž řešení není jednoznačné. Analyzovaná událost nemá pouze charakter obtížné učební úlohy vztahující se k osvojování faktů, ale kromě kognitivního úsilí také vyžaduje, aby se studenti při jejím řešení učili promyšleně jednat a zvládat problémy, které přináší praxe. Můžeme říci, že tyto vyučovací metody mají z pohledu obsahu učiva přesahující charakter a jsou spojovacím můstkem mezi teorií a praxí. Proto je jich vhodné využívat v pedagogickém procesu osobnostního a sociálního rozvoje, a to zejména při analýze událostí ze společenského života, při nácviku organizačních činností, při osvojování dovedností správného rozhodování ve složitých př́padech a nezvyklých situacích apod. Jejich průběh Ize přiblížit na základě níže uvedených fází (Maňák, 2003; Kotrba \& Lacina, 2007):

a) Volba a specifikování tématu, jež by mělo být v souladu s výukovým záměrem a odpovídat připravenosti studentů.

b) Seznámení s materiály, které mohou mít povahu dokumentů, písemností, obrazů, TV nahrávek apod.

c) Vlastní studium případu uskutečňující se za podpory učitelelektora, který žáky-studenty do problematiky uvádí, vytyčuje s nimi sledované cíle a poskytuje jim úvodní rady a pokyny.

d) Prezentace návrhů, argumentů, závěrů, jejichž význam a př́nos je konfrontován s reálnými skutečnostmi praxe. Pokračovat v řešení případu se může metodou hraní rolí, prrípadně jinými metodami. 
Situační metody prošly od svého vzniku značným vývojem, přičemž došlo $\mathrm{k}$ jejich hlubšímu propracování a ke vzniku četných nových variant a typů. K osvědčením typům patří: metody rozboru situace, řešení konfliktní situace, řešení dynamické situace, basketová metoda a další. $V$ krátkosti popíšeme jen ty varianty, které jsou $v$ modifikované formě využitelné v pedagogickém procesu osobnostního a sociálního rozvoje:

$\rightarrow$ Metoda rozboru situace patří mezi základní a původní situační metody. Je založena na pečlivém individuálním studiu písemných materiálů, po němž následuje diskuse ve skupině - v plénu pod vedením pedagoga-lektora. Složitější prípady se mohou projednávat v menších skupinách, dílčí závěry se posléze shrnují v plénu. Dưraz se klade na logické usuzování, samostatné myšlení, na analýzu a hodnocení situací, hledání možných variant a výběr optimálního řešení.

$\rightarrow$ Řešení konfliktní situace probíhá poněkud odlišně, protože její těžiště spočívá v osobních vztazích. Využívané konfliktní situace vycházejí z reálných konfliktů, které se již v běžné praxi a životě staly, týkají se názorů, postojů, zájmů, v nichž většinou dochází ke kontroverznímu střetávání. $Z$ tohoto pohledu mají situační metody v pedagogickém procesu osobnostního a sociálního rozvoje plnohodnotné využití. Studenti se seznámí s rozporným př́padem formou krátké zprávy, ústního sdělení, avšak podané úvodní informace se už nedoplňují, ale od účastníků se inned vyžadují návrhy na řešení. I když se nutně nemusí nalézt uspokojivé řešení konfliktní situace, protože k vytvoření jednoznačných závěrů není k dispozici dostatek informací, je tento typ metody považován za př́nosný, nebot' učí studenty se rychle a efektivně rozhodovat $v$ časové tísni a při neúplné znalosti 
potřebných údajů. Metodu Ize obohatit o alternativní konfliktní situaci, kde jsou po skončení diskuse uvedena nová fakta, která mění podmínky dané situace. Začíná nová diskuse, poukazuje se na vliv nových vstupních informací a podmínek řešení problému. Alternativní konfliktní situace se snaží řešit problém statičnosti situačních metod a naučit studenty reagovat na změnu podmínek v čase.

$\rightarrow$ Metoda incidentu je obdobou metody konfliktních situací s cílem naučit studenty pokládat správné otázky, které vedou k řešení situace. Její podstatou je incident - určitá rušivá událost, př́hoda. Pedagog řekne studentům stručnou zprávu a vyzve je, aby pomocí dotazů na konkrétní jevy ve zprostředkované situaci získali potřebné informace pro hlubší analýzu, stanovili př́činy problému a navrhli potřebná opatření. Všechny otázky musí být určité, přesně zacílené. Doporučuje se, aby fáze dotazů trvala maximálně 15 minut. Pedagog neříká žádné informace navíc, jen odpovídá na dotazy. Studenti se musí orientovat ve složitých a nejasných situacích, odhalovat výsledek jednání. Vliv na jejich řešení mají předchozí zkušenosti, logická analýza, ale také znalosti z oblasti psychologie. $U$ této metody je velice důležitá role zprostředkovatele príběhu - pedagoga, který musí znát príiběh do všech detailů a podmínek, jež mohou hrát při řešení významnou roli. Po analytické části následuje vlastní řešení př́padu, do něhož pedagog již nezasahuje. Řešení probíhá formou diskuse v plénu. Na závěr se nejčastěji hodnotí následující kritéria (Ouroda, 2000; Kotrba \& Lacina, 2007):

a) Aktivita jednotlivých studentů: kdo se nejvíce ptal, jaké padaly otázky, jestli se studenti ptali na podstatná nebo nepodstatná fakta príběhu. 
b) Zhodnocení řešení prípadu a prríčin: pedagog hodnotí, zda si studenti nevymýšleli, nedoplňovali a sami neupravovali skutečnosti.

c) Celkové zhodnocení prínosu k řešení příkladu: týká se vyzdvihnutí všech kladů a záporů, dále pak uvedení, jak je možno zabránit řešenému incidentu, př́ípadně jak byl reálně řešen.

$\rightarrow \quad$ Metoda postupného seznamování s případem ( $v$ některých publikacích je uvedena pod názvem dynamická situační metoda, např. Maňák, 2003) řeší složité komplexní problémové situace rozložené do delšího časového úseku. V odborných publikacích (např. Maňák, 1997, 2003; Kotrba, 2005; Kotrba \& Lacina, 2007) se nejčastěji uvádějí následující varianty:

a) Situace je formulována tak, že studentům jsou podány všechny základní informace, které jsou nutné k poznání a řešení problému. Tyto informace jsou jim sdělovány postupně, v jednotlivých vývojových stádiích, tak jak se situace vyvíjela v reálném životě. Za optimální se považuje pět až šest etap (neboli přerušení předávání informací) v maximální celkové délce dvou hodin.

b) Další variantou je předložení několika možných variant řešení. Studenti je musí analyzovat a rozhodovat se pro optimální alternativní řešení. Zde se považuje za vhodné pedagogovo závěrečné zhodnocení řešení, např.: Co bylo podstatou problému, jak se vyvíjelo řešení jednotlivých skupin, kde se dělaly nejčastěji chyby, jak je vhodné postupovat v budoucnosti, prrípadně opět popsat, jak se situace vyvíjela v reálné praxi. 
c) Poslední možností je takové zadání situace, které neobsahuje všechny nezbytné a důležité informace k vyřešení př́ipadu. Studenti si musí nejdříve po své analýze chybějící informace zjistit, doplnit, opatřit. To Ize provést bud' samostudiem nebo pomocí prímých, konkrétních otázek na pedagoga. Otázkami si studenti zjišt'ují další nezbytná fakta. Pedagog nesděluje sám od sebe žádnou informaci navíc. Odpovídá pouze na to, na co se ho studenti ptají.

\section{Inscenační metody}

Inscenační metody bývají v různých kontextech a koncepcích označovány různými termíny. Např. hraní rolí, interakční hry, scénické hry atd. Bratrská uvádí, že „,podstatou inscenačních metod je sociální učení v modelových situacích, v nichž účastníci edukačního procesu jsou sami aktéry předváděných situací" (Bratská, 1992, s. 92). Maňák doplňuje, že v nich jde o simulaci nějaké události, v níž se kombinuje hraní rolí a řešení problému, a to bud' předváděním určitých lidských typů, nebo zobrazováním reálných životních situací, nebo kombinací obou postupů. $V$ předváděné dramatizaci problémových případů se prohlubuje osvojené učivo, objasňují se otázky lidských osudů, osvětlují se motivy a city lidí, umožňuje se pochopit a prožít hloubku mezilidských vztahů, a to vlastním prožíváním a jednáním. (Aktuálním tématem může být např. xenofobie, obavy z globalizace, nesmyslnost válek, situace žen ve společnosti atd.). Pro žáky - studenty inscenace znamená možnost získat nové prožitky, osvojit si adekvátní způsoby chování a jednání, seznámit se s formami vystupování typickými pro budoucí profesi apod. (Maňák 2003, s. 124). Z uvedené charakteristiky je patrné, že 
inscenační metody poskytují velký prostor k rozvoji osobnosti, ke kultivaci všech psychických procesů, zejména však zintenzivňují prožívání zobrazovaných osudů, vztahů a interakčních pochodů. Hlavní přínos inscenačních metod není v předvedení dramatické kreace, ale v procesu, který k ní vede, a v postojích, které vyvolává. Průběh inscenace se člení na několik fází, jež se podle charakteru zpodobňovaného př́iběhu různě obměňují. Nejčastěji se uvádějí tyto fáze (např. Bláhová, 1998; Machková,1999; Maňák, 2003):

1. Príprava inscenace: zahrnuje stanovení cíle, konkretizaci obsahu, časový plán, rozdělení rolí a vytyčení postupu.

2. Realizace inscenace: $v$ této fázi dostávají jednotliví aktéři pokyny k zpodobení daných postav. Při nácviku inscenace se připouštějí rozmanité kombinace provedení, počítá se s improvizacemi.

3. Hodnocení inscenace: koná se bezprostředně po jejím ukončení. Hodnocení se může uskutečňovat formou diskuse v plénu, diskuse ve skupinách, pomocí připravených otázek, na základě záznamu inscenace nebo individuálně s každým účastníkem.

V pedagogické praxi se využívá několik variant inscenačních metod. Nejčastěji jsou uváděny (např. Maňák, 2003; Machková, 1980, 1992, 2007; Valenta, 1997, 2008):

$\rightarrow \quad$ Strukturovaná inscenace: je většinou založena na promyšlené stavbě děje, opírá se o předem připravený scénář a realizuje se obvykle v jedné větší skupině účastníků. $M$. Janovcová zdůrazňuje, že role nesmí být v žádném případě rozvedeny do dialogů, protože jde především o obsahové, verbální a afektivní ztvárnění role 
samotnými studenty. Scénář by měl podle možností počítat s rolemi pro všechny účastníky, ale s větším zřetelem na role hlavních protagonistů. Specifickou formou je inscenace s dvěma herci, při které může být vybráno více herců na jednu roli, jíž si postupně v průběhu inscenace předávají.

Účastníci v úvodu dostanou čas na seznámení se scénářem a se svojí rolí. Pedagog působí zároveň jako poradce, př́ípadně jednotlivcům vysvětluje, kdo koho bude hrát, jak se má dotyčný v inscenaci chovat, jaké jsou jeho postoje a cíle, případně jaké by měl používat argumenty. Popis výchozí situace dostanou všichni studenti, avšak pouze vybraní aktéři obdrží popis své role a charakteristiku osobnosti a svůj záměr.

Zdárný průběh strukturované inscenace záleží také na jejím uvedení. Možností, jak uvést strukturovanou inscenaci je několik. K uvedení do situace je kromě ústního vysvětlení možno využít filmovou, televizní nebo divadelní nahrávku, jež má instruktážně-motivační charakter, na jejím základě účastníci děj dohrávají (Jankovcová, 1988, s. 152).

$\rightarrow \quad$ Nestrukturovaná inscenace je zaměřena na řešení konkrétní situace ze života. Všichni studenti mají k dispozici pouze popis výchozí situace, nikoli popis jednotlivých rolí. Doporučuje se proto zařazovat nestrukturované inscenace do pedagogického procesu až tehdy, kdy studenti získají zkušenosti se strukturovanými inscenacemi. Z výše uvedené charakteristiky vyplývá, že tyto formy inscenace jsou založené na improvizaci, tudíž kladou větší nároky na účastníky.

Autoři (např. Maňák, 1997; Kotrba \& Lacina, 2007) se shodují na tom, že počet účastníků - herců v nestrukturované inscenaci by měl být 
menší, přibližně se doporučují 2-3 osoby. Délka trvání inscenace je kratší - obvykle trvá 5 až 10 minut, v ojedinělých př́padech 20 minut. Protože mají účastníci k dispozici pouze popis výchozí situace, je samotné uchopení role plně jen v jejich kompetenci, obsahové ztvárnění a délka inscenace se tedy odvíjejí od jejich improvizačních a tvưrčích schopností.

Nedílnou součástí strukturované a nestrukturované inscenace v pedagogickém procesu osobnostního a sociálního rozvoje je role pozorovatele, jíž se ujímají studenti, kteří nemají zadané role. Od pedagoga dostanou úkoly a otázky, na které se snaží prostřednictvím vlastního pozorování a úsudku odpovědět. $\vee$ průběhu inscenace vypracovávají písemné poznámky, vyjadřují se především k jednotlivým dějovým sekvencím zahrané inscenace, např. komentář ke ztvárňování rolí (jak byly role zahrané, jakým způsobem by role ztvárnili sami), analýza dějové linie (o co šlo v zahrané inscenaci, jak se vyústění děje shoduje se skutečností) apod.

Za složitější variantu inscenačních metod je považováno tzv. mnohostranné hraní úloh (Multiuple Role Plating). Kotrba Lacina uvádějí následující podmínky jejího využití v pedagogické praxi (2007, s. 131):

$\rightarrow \quad$ Všichni studenti jsou zapojeni do inscenace a každý hraje svou roli. Počet rolí závisí na počtu zúčastněných. $V$ této variantě je velice důležitý výběr inscenace. Vhodné jsou např. rozsáhlé simulační hry, kdy každý hráč má svoji úlohu a zastává určitou roli.

$\rightarrow$ Rozdělení studentů do skupin a oddělené a souběžné hraní inscenací po skupinách. Studenti jsou rozděleni do skupin podle počtu rolí v inscenaci - obvykle 5 až 6 . Pokud některý z účastníků 
přebývá, stane se pozorovatelem určité skupiny. $\vee$ každé inscenaci je stanovena role vedoucího-režiséra, který dostane nejdetailnější popis své role a vede celou inscenaci. Součástí této role je vypracování závěru zahrané inscenace, který může mít formu stručného shrnutí.

Nevýhodou metody mnohostranného hraní rolí v pedagogickém procesu osobnostního a sociálního rozvoje je menší přehlednost pedagoga o průběhu inscenací než u výše popisovaných dvou typů inscenací. Pedagog nedokáže $v$ jednom okamžiku sledovat všechny skupiny. Tato nevýhoda se projevuje v nedostatku získávání informací potřebných pro reflexi a rekapitulaci průběhu tvorby a realizace inscenace. Navíc prístupy studentů mohou být $v$ různých skupinách odlišné. Od tzv. nic nedělání přes pouhé čtení napsaných vět a scénářủ až po opravdové ztvárnění zadaných rolí. Z této skutečnosti vyplývá doporučení, že uvedená varianta ,"hraní rolí “ je vhodná pro studenty, kteří s inscenačními metodami mají základní zkušenosti a jsou motivováni k plnění jednotlivých zadání.

\section{Didaktické hry}

Dalšími aktivizujícími metodami, jež mají široké využití v pedagogickém procesu osobnostního a sociálního rozvoje, jsou didaktické hry založené na řešení problémových úloh a situací. Jankovcová hru z obecnějšího hlediska definuje jako „soubor seberealizačních aktivit jedinců nebo skupin, které jsou vázány danými, prèedem domluvenými pravidly a jejichž primárním cílem není ani materiální zájem, ani užitek" (1989, s. 152). Ze socializačního aspektu hru definuje Maňák jako ,jednu ze základních forem činnosti člověka (vedle práce a učení), pro niž 
je charakteristické, že je to svobodně zvolená aktivita, která nesleduje žádný zvláštní účel, ale cíl a hodnotu má sama v sobě“ (2003, s. 126). Z hlediska potřeb pedagogické záměru Ize hru charakterizovat $v$ duchu pedagogických klasiků (např. Komenský, Schleimacher, Fröbel, Montessoriová) jako „takovou seberealizační aktivitu jedinců nebo skupin, která svobodnou volbu, uplatnění zájmů, spontánnost a uvolnění přizpůsobuje pedagogickým cílům" (Maňák, 2003, s. 127). $Z$ uvedené definice je možné nastínit jedno klíčové dilema, s nímž se často setkáváme v pedagogickém procesu osobnostního a sociálního rozvoje, a to je rozpor mezi prirozenou podstatou hry a jejím didaktickým záměrem. Bönsch upozorňuje na skutečnost, že v pedagogickém procesu nesmí na jedné straně sledování učebních cílů tak silně překrývat vlastní podstatu hry, že student již hrové činnosti nevnímá jako hru, na druhé straně neúčelnost a volnost hry nemůže jít tak daleko, že se zcela vytratí cíl výuky (Bönsch, 2006, s. 107). Na uvedené dilema Ize reagovat myšlenkou (Jankovcová, 1989; Houška, 1991, 1993, 1995; Maňák, 2003), že didaktická hra si zachovává většinu znaků hrových činností, takže studenti si jistou omezenost didaktické hry danou jejím usměrňováním a cílovou orientací při správném pedagogickém vedení ani př́iliš neuvědomují.

Didaktické hry zahrnují velké množství aktivit, jež lze utř́́dit z různých hledisek. Lze je dělit podle délky trvání (krátkodobé, dlouhodobé), místa konání (místnost, louka, les, hřiště atd.), svého zaměření a účelů (s důrazem na opakování vědomostí, pohybově zaměřené hry, stresové situace nebo cílem může být záměrný rozvoj osobnostních a sociálních dovedností). Obecné dělení her je však založeno na míře interakce mezi hráči, př́padně herními týmy. Z tohoto pohledu (napr. Meyer, 2000; Kotrba \& Lacina, 2007) Ize hry rozdělit na: 
$\rightarrow$ Neinterakční hry: jejich podstata spočívá v zamezení vzájemného ovlivňování hráčů. Všechny herní týmy (nebo jednotlivci) řeší stejný problém, a to za stejných podmínek. Příkladem mohou být různé vědomostní a diagnostické testy, otázkové hry, doplňovačky, slepé mapy, šifrované texty, skrytá slova a další. $V$ pedagogickém procesu osobnostního a sociálního rozvoje se využívají k nácviku tvořivosti, konvergentního myšlení, k procvičování soudů a úsudků apod.

$\rightarrow$ Interakční hry: jsou založeny na vzájemné interakci mezi účastníky při plnění zadaných úkolů. Každý účastník je ovlivňován chováním druhých a své chování přizpůsobuje okamžité herní situaci. $\checkmark$ pedagogickém procesu osobnostního a sociálního rozvoje mají interakční hry složitější charakter. Významnou roli v nich hrají vztahy uvnitř skupin-herních týmů jako jsou např́iklad schopnost dělby práce, úkolů, integrace a participace všech účastníků apod. 


\subsubsection{Specifické herní aktivity/techniky využívané v kurzech osobnostně sociálního rozvoje}

1.2.4.1 Metodika specifických herních aktivit/technik využívané $v$ kurzech osobnostně sociálního rozvoje

Ve výuce, která je primárně zaměřena na osobnostní a sociální rozvoj, se používají specifické herní aktivity/techniky. Techniku můžeme vymezit jako postup, který není do detailu dotvořen, ale je dopracován podle konkrétní situace, požadavků a potřeb účastníků kurzu. Mnohé techniky mají různé použití podle toho, na co se při jejich aplikaci klade důraz. Každá technika má své možnosti, přínosy, ale také svá rizika. (Svoboda, 2017, s. 40) Jedním z dalších základních rysů technik využívaných v pedagogickém procesu osobnostního a sociálního rozvoje je přesná metodická struktura v jejich aplikování v kurzech vysokoškolské výuky. Na základě odborné literatury (např. Hermochová, 1982, 1988, 1994; Neuman, 1999; Valenta, 2000, 2006; Komárková, Slaměník, \& Výrost, 2001; Svoboda, 2004; Pelánek, 2008) ji můžeme vyjádřit následujícím způsobem:

\section{Cíl (zaměření techniky) $\rightarrow$ Instrukce $\rightarrow$ Akce (průběh techniky) \\ $\rightarrow$ Reflexe $\rightarrow$ Evaluace}

Výše uvedené didaktické atributy v krátkosti popíšeme.

\section{Cíl (zaměření techniky)}

Výběr a následně cíl - zaměření techniky se odvozuje od obecných témat pedagogického procesu osobnostního a sociálního rozvoje: k sobě, k druhým, k hodnotám, existenci člověka. 
Na začátku realizace každé techniky je důležité si položit následující otázky: Co technikou sledujeme? Čeho chceme prostřednictvím techniky dosáhnout? Jaký prínos bude mít technika pro účastníky a skupinu?

Techniky pedagogického procesu osobnostního a sociálního rozvoje mohou mít univerzální charakter, co se cílů a zaměření týče. Jedna a ta samá technika se může využít pro více cílových témat, např. kreativita, komunikace, kooperace, způsoby řešení interpersonálních konfliktů, prosociální chování vůči druhým apod. $Z$ tohoto důvodu si pedagog musí přesně vymezit, na jakou cílovou oblast se při práci s technikou zaměří. Podrobné vymezení cílů - zaměření techniky výrazně ovlivňuje další složky metodické struktury v realizaci techniky, a to především instrukci a reflexi.

\section{Instrukce}

Instrukce je soubor různých pravidel a informací o podmínkách realizace techniky využívané v pedagogickém procesu osobnostního a sociálního rozvoje. Neuman (1998, s. 38) zdůrazňuje, že instrukce má být promyšlená, u složitějších technik dokonce napsaná. Její výklad by měl být stručný a jasný. Instrukce by se neměla v průběhu realizace techniky bez vážných důvodu měnit. Můžeme se ale $v$ průběhu realizace techniky dostat do situace, ve které je potřeba instrukci přizpůsobit aktuálním podmínkám.

V odborné literatuře a $v$ metodických materiálech se vyskytuje mnoho dělení instrukcí. Např. Valenta (2008, s. 278) ve vztahu k metodám dramatické výchovy typologizuje instrukce následujícím způsobem: instrukce z hlediska činitele, který ji předkládá (instrukce pedagoga, instrukce studenta); instrukce z hlediska 
převažujícího typu právě prožívané skutečnosti (pro nehrovou skutečnost, pro hrovou skutečnost); instrukce z hlediska rámce, v němž ji činitel předkládá („,za sebe“ - ve své reálné sociální roli nebo $v$ roli postavy, ale z pozice člověka, který hru ř́́dí...); instrukce z hlediska komunikačního kódu (verbální, nonverbální, paralingvistická, demonstrační); instrukce z hlediska zajištění základních prvků dramatické hry (obsahující specifické prvky dramatické výchovy - vlastního hraní role v situaci, např. vymezující okolnosti situace, jádro situace... apod.; obsahující prvky týkající se technického zabezpečení hry a jejího provozního zajištění); instrukce z „hlediska akčního rádiu“ - množství instruovaných osob (instrukce veřejná, instrukce soukromá); instrukce z hlediska jejího časového vztahu k činnosti (instrukce předchází v čase činnosti, kterou instruuje, instrukce probíhá současně s činností, kterou instruuje). Další dělení instrukcí bývají většinou dle různých forem prezentace, užívaných pomůcek apod.

Instrukce bývá často první informací o technice, která je účastníkům uváděna. Způsob uvádění techniky musí reagovat na úroveň skupiny, ke které je promlouváno a která je vedena. Neuman (1998, s. 35) zdůrazňuje, že se jedná o důležitou fázi, jež rozhodne o potencionálním úspěchu techniky a vlivu na skupinu. Autor doporučuje, aby při výkladu pedagog zaujal př́hodné místo, aby na každého viděl, a využil tak očního kontaktu s členy skupiny. Efektivita uvádění techniky se zvýší tím, když organizátoři vytvoří přitažlivou atmosféru plnou napětí a očekávání, např. vhodnou hudbou nebo vyzdobením prostředí.

Při uvádění instrukcí technik využívaných v pedagogickém procesu osobnostního a sociálního rozvoje je v některých prípadech vhodné 
používat legendy, různé motivy nebo přehrávání dramatických výstupů. Čím živěji probíhá instrukce techniky, tím lépe se podaří upoutat pozornost účastníků. Důležitým krokem po prezentaci techniky je zadávání doplňujících otázek, které mají účastníkům napomoci ozřejmit nejdůležitější sekvence techniky a pedagogům poskytnout zpětnou vazbu o tom, zda instrukce byla pro každého účastníka srozumitelná.

\section{Akce (průběh techniky)}

Pedagog může svým způsobem řízení výrazně ovlivnit průběh techniky, a to v pozitivním nebo negativním slova smyslu. Z odborné literatury je možné vyvodit (např. Hermochová, 1982, 1988, 1994; Neuman, 1998; Valenta, 2000, 2006; Komárková, Slaměník, \& Výrost, 2001; Pelánek, 2008) základní zásady organizování a řízení průběhu sociálně psychologické techniky.

V literatuře se uvádí, že v průběhu techniky je žádoucí, aby pedagog zastával aktivní roli. Např. v dynamičtějších technikách může povzbuzovat a vést účastníky k tvưrčímu chování při plnění výcvikových úkolů. Mezi důležité úkoly pedagoga patří systematické sledování průběhu techniky. Za nežádoucí se považuje zlehčování řešení a výkonu účastníků, a to i v situacích, které nabízejí jejich tvořivější a angažovanější přístup. Často se stává, že průběh techniky se nevyvíjí podle představ organizátorů, i v tomto př́ípadě je vhodnější nechat rozehrané technice volný průběh a nezasahovat do děje. $V$ prípadě neodkladné intervence je velmi důležité zvážit způsob udílení rad, protože i dobře míněná rada může být později vnímána jako zásah do autonomie skupiny. V průběhu techniky je 
občas nutné připomenout základní a důležitá pravidla. Obecně platí, že každá technika nemusí skončit splněním úkolu. Někdy je dokonce práce s neúspěchem pro skupinu potřebná.

\section{Reflexe}

Reflexe je posledním a mnohdy nejobtížnějším metodickým krokem $v$ realizaci technik využívaných $v$ pedagogickém procesu osobnostního a sociálního rozvoje. Právě v řízené a záměrné reflexi spočívá rozdíl mezi technikou, která se uskutečňuje v rámci volnočasových aktivit, a technikou, která je součástí procesu záměrného rozvoje osobnostních a sociálních předpokladů.

Neuman (1998, s. 39) uvádí, že v anglicky psaných odborných publikacích, $v$ nichž byly postupy reflexe zpracovány, se setkáváme s termíny reflexion, reviewing, debriefing, processing a appraisal. Všechny vyjadřují proces zpracování údajů s přihlédnutím k tomu, co se už událo.

Neuman (1998, s. 40) dále uvádí, že charakteristiku a funkci reflexe odvozujeme z průběhu zkušenostního učení. Po absolvování určité činnosti (např. techniky využívané v pedagogickém procesu osobnostního a sociálního rozvoje) se ohližíme zpět, abychom hledali souvislosti mezi výsledkem akce a činností jednotlivců i celé skupiny. Srovnáváme své zkušenosti a prožitky s jinými členy skupiny. Zpřesňujeme jejich význam.

Na základě výše uvedených charakteristik a významu reflexe v technikách využívaných v pedagogickém procesu osobnostního a sociálního rozvoje se pokusíme o její definování. 
Reflexi můžeme chápat jako záměrný a rámcově předem promyšlený interaktivní proces, při kterém dochází u jedince k rekapitulaci klíčových momentů v jeho chování a prožívání ve vztahu k cílům techniky. Účelem je, aby jedinec získal vhled do svých intrapersonálních a interpersonálních dovedností.

Námi uvedená definice nahlíží na reflexi jako na záměrný, předem promyšlený a řízený proces, v němž jedinec získává potřebný vhled do svých osobnostních a sociálních předpokladů. Další definici nabízí psychologický slovník: „Reflexe je druh sebepozorování, obracení myšlení do sebe, do vlastního vědomí a prožitkư“ (Hartl \& Hartlová, 2000, s. 502). Tato definice upozorňuje na sebepozorování jako na jednu z důležitých funkcí každé efektivně vedené reflexe. Jedním z nepostradatelných prostředků sebepozorování a zároveň zdrojem pro získávání důležitých informací podněcující osobností a sociální rozvoj jedince je zpětná vazba. Otázkou je: Co je to zpětná vazba a jaký význam má v reflexi technik pedagogického procesu osobnostního a sociálního rozvoje?

Hermochová (1982, s. 129) zpětnou vazbu charakterizuje jako proces, ve kterém je podávána informace jiné osobě o tom, jak ji druzí vnímají, chápou a prožívají její chování. Stupeň a hloubka zpětné vazby závisí na stupni důvěry mezi členy skupiny. Autorky Reitmayerová a Broumová poukazují na skutečnost, že v technikách pedagogického procesu osobnostního a sociálního rozvoje by měla být zpětná vazba cílená, záměrná a předem promyšlená. Podle zmiňovaných autorek Ize cílenou zpětnou vazbu považovat „za proces, při němž skupina verbálně zpracovává zážitek z předcházející aktivity pod vedením instruktora, který určuje cíl a průběh zpětné vazby a má kontrolu i nad parametry aktivity samé" (2007, s. 13). 
Cílená zpětná vazba by měla vést $\mathrm{k}$ tomu, aby člověk lépe porozuměl nejen svému prožívání a chování, ale i ostatních členů skupiny, a došel k tomuto poznání na základě vlastních zkušeností, vlastní cestou. Aby bylo tohoto výsledku dosaženo, musí být cílená zpětná vazba naplněna ve svých dvou funkcích: predikující a intervenující. Predikující funkce pomáhá jedinci předvídat reakce a chování své i svého okolí. Záměrem intervenující funkce je zlepšit postup jedince, aby dosáhl žádoucího způsobu chování svého nebo chování okolí. Pro plné uplatnění obou funkcí je potřeba, aby byl daný jedinec schopen a ochoten jejich náplň uskutečnit. (Reitmayerová \& Broumová, 2007, s. 14).

Obecně lze konstatovat, že zpětná vazba má v efektivním a smysluplném naplňování technik využívaných v pedagogickém procesu osobnostního a sociálního rozvoje nezastupitelnou roli. Její prrínos můžeme spatřovat především v tom, že prohlubuje a zkvalitňuje interpersonální percepci a tím usnadňuje dorozumění a přispívá ke vzniku pevnějších vazeb mezi členy skupiny. Vyvolává a podporuje takové formy chování, které skupině prospívají, a naopak koriguje takové projevy v chování, které nepřispívají záměru realizovaných technik osobnostního a sociálního rozvoje. Hlavní přínos můžeme rovněž spatřovat v obohacování a „,posouvání“ samotných účastníků z hlediska rozvoje jejich osobnostních a sociálních předpokladů. Účastníci prostřednictvím cíleného zpětnovazebního procesu dostanou podněty, jež jim umožňují adekvátněji vnímat vlastní osobu.

Hermochová (1982, s. 130) ve vztahu k sociálně psychologickému výcviku uvádí, že proces zpětné vazby by měl v technikách probíhat následujícím způsobem: 
a) sdělíme druhým, co si myslíme sami o sobě

b) sdělíme druhým, co si myslíme a co cítíme ve vztahu k nim

c) dojde ke vzájemné výměně informace a jejich srovnání

Jedním z důležitých kroků v aplikaci technik pedagogického procesu ve vysokoškolském vzdělávání je naučit studenty pravidlům poskytování zpětné vazby. Mezi nejužívanější pravidla zpětné vazby patř́:

a) Zpětná vazba má být popisná, méně hodnotící, interpretující či hledající motivy. U sebe i u druhého pouze popisujeme reakci, nezabýváme se morálním hodnocením, jež často vede ke vzniku odporu a tendenci se bránit.

b) Zpětná vazba má být co nejkonkrétnější - ne formulovaná obecně. Např. řekneme-li někomu, že se chová dominantně, je pro něj tato informace méně hodnotná, než když řekneme: „právě ted', když jsme spolu o této věci hovořili, jsi nenaslouchal tomu, co říkají ostatní; měl jsem pocit, že bys se mnou přestal mluvit, kdybych s tebou nesouhlasil.“

c) Zpětná vazba musí být obsahem i formou přiměřená tomu, komu ji dáváme, a jasně a přesně formulovaná.

d) Zpětná vazba by měla být vztahována $k$ těm oblastem, v nichž je možné u účastníků výukového programu dosáhnout/navodit změny. Když je někdo informován o něčem, co ovlivnit nemůže, frustruje ho to.

e) Zpětná vazba je tím účinnější, čím více je vyžadována. Nejúčinnější je tehdy, když o ni jedinec sám požádá. 
f) Zpětná vazba by měla být dána vždy v pravý okamžik - obvykle co nejdříve po události, ke které se vztahuje.

g) Zpětná vazba by měla být obsahově správná. Ve skupině ke konfrontaci využíváme názorů ostatních.

Se zpětnou vazbou úzce souvisí další krok, který je součástí každé systematické reflexe. Tento krok spočívá v pohledu dopředu a ukazuje jedinci, jak může nabyté zkušenosti využít v dalším jednání a jaké jsou možnosti transferu nově získaných zkušeností z technik osobnostního a sociálního rozvoje do běžného života.

Základem úspěšně vedené reflexe je vhodná formulace otázek. Pedagog klade otázky, které se vztahují k zaměření techniky nebo ke stanoveným cílům výukového bloku. Rozhodně je žádoucí vyvarovat se otázek, na něž účastníci odpovídají jen „ano“ nebo „ne.“ Př́nosnější pro zvyšování osobnostních a sociálních předpokladů jedince jsou otázky otevřeného typu: Co jste si na základě prožité techniky uvědomili? Jak hodnotíte spolupráci ve skupině? Jakým způsobem jste se snažili ve skupině prosadit? Dále je potřeba volit otázky, na které je možné konkrétně odpovídat, je vhodné se vyvarovat užívání různých abstraktních pojmů z oblasti psychologie osobnosti, sociální psychologie a dalších oborů společenských věd.

Za inspirující způsob kladení otázek v rámci systematické a řízené reflexe Ize považovat postup jež je využíván R. Greenawaem (1993, s. 45) s označením „FFFF“ - Facts - Feelings - Findings - Futures. Do češtiny se nejčastěji tento postup překládá (Reitmayerová \& Broumová, 2007) „PPPP“: Průběh - Pocity - Poznatky - Přiležitosti. Význam uvedeného postupu spočívá v tom, že pedagog pokládá 
čtyři okruhy otázek, které následují jeden po druhém a ukotvují postupně zážitky studentů. Jednotlivé složky tohoto postupu můžeme charakterizovat následujícím způsobem:

Průběh slouží k formulování toho, co se skutečně stalo; k prostému popisu dění. Otázky jsou cílené na konkrétní události, jejich popis, detaily, např:: Jak byste zrekapitulovali průběh celé techniky? Které okamžiky považujte $v$ technice za zlomové a proč? Jak probíhaly jednotlivé etapy (zadání, domlouvání taktiky, průběh techniky, dosažení výsledků) techniky? Stalo se v technice něco neobvyklého a pro vás překvapujícího? Popište průběh techniky z pohledu nezávislého pozorovatele... apod.

Pocity a dojmy jsou důležitým psychickým stavem vztahujícím se k prožitku z proběhnuvší techniky. Otázky jsou nejčastěji zaměřeny na emoční reakce, emoční stavy a dojmy, např. Vyjmenujte a charakterizujte nejsilnější pocity, které jste zažívali. Myslíte si, že jste prožívali obdobné pocity jako ostatní? Ve kterém okamžiku jste proživali pocity radosti a euforie, a ve kterém naopak pocity zklamání? Co bylo spouštěčem vašich emocí, at' už pozitivních či negativních? Jak se měnily vaše pocity v průběhu techniky? Pocity, které jste prožívali, jsou charakteristické pro vaši osobu nebo byly výjimečné? apod.

Poznatky jsou vyvozovány účastníky na základě hledání souvislostí mezi jednotlivými prožitky. Otázky odkrývají zjištění, která z toho plynou, např. Zobecněte, co bylo ve tvorbě postupu zásadní. Jaká pravidla komunikace byla respektována a která naopak porušována? Zrekapitulujte charakteristiku týmových rolí, jež účastníci zastávali. Jaké další okolnosti přispěly ke zdárnému/ nezdárnému dokončení techniky? Naformulujte desatero zásad efektivní komunikace, spolupráce... apod. 
Přiležitosti se vztahují k souvislostem spojeným s budoucím chováním v podobných situacích, do kterých se jedinci mohou dostat. Otázky se orientují na možnosti využití získaných zkušeností, např. Jaké vědomosti a dovednosti jste získali v této technice? Co ze získaných zkušeností můžete využít v běžném životě? Jaké překážky vám $v$ životě budou bránit $v$ tom, abyste nově získané zkušenosti mohli využít v běžných životních situacích? Které z poznatků vztahující se k této technice byly pro vás nové a které naopak už běžně využíváte? Co potřebujete ještě pro to, abyste dokázali efektivním způsobem nově získané zkušenosti zakomponovat do běžného života? apod.

Další vodítkem pro směrování výběru otázek může být rámcový postup pro řízení a směrování reflexe, který nabízí Švec. (2002, s. 57) Jeho návod Ize shrnout do následujících bodů:

$\rightarrow \quad$ Prvně se reflexe týká generálních, tzn. základních, celkových, hlavních dojmů. Např.: Jaká byla pro Vás technika, které jste se právě zúčastnili (jednoduchá, středně náročná, obtížná apod.)? Charakterizujte, popište, přirovnejte nejsilnější dojmy, které z techniky máte? apod.

$\rightarrow$ Dále se přistupuje k popisu průběhu aktivity. Např.: Zrekapitulujte průběh celé techniky. Jak probíhaly jednotlivé etapy techniky (zadání, domlouvání taktiky, průběh techniky, dosažení výsledků)? Popište průběh techniky z pohledu nezávislého pozorovatele... apod.

$\rightarrow \quad$ Následně je vhodné reflexi směřovat k emocím účastníků. Např.: Vyjmenujte a charakterizujte nejsilnější pocity, které jste zažívali. Co bylo spouštěčem vašich emocí, at’ už pozitivních či negativních? Jak se měnily vaše pocity v průběhu techniky? apod. 
$\rightarrow$ Předmětem dalšího kroku reflexe jsou otázky, které se týkají skupinového dění. Např.: Kdo zaujímal ve skupině převážně dominantní a kdo submisivní pozici? Plnila skupina zadání jako jeden tým nebo vznikaly podskupinky? Kdo měl ve skupině nejvíce př́nosných nápadů, kdo dokázal myšlenky druhých „dotahovat" do konce apod.? Bylo těžké se ve skupině prosadit? Zapojovali se do řešení zadaného úkolu všichni? Dodržovala skupina předem stanovená pravidla? apod.

$\rightarrow \quad$ Z pohledu edukačního procesu je důležité se při „,reflektováni““ zaměřit na cíle výukového bloku a význam jednotlivých technik. Např: Jaký př́nos pro vás technika měla? Jaké zkušenosti jste z uvedené techniky získali? U téma sociální komunikace: Zformulujte pravidla pro dosažení konsenzu ve skupin. Které z naformulovaných pravidel je pro vás obtížné dodržet a proč? apod.

$\rightarrow$ Reflexe může být ukončena zobecněním získaných zkušeností a diskusí o jejich transferu do běžného života. Např.: Které ze získaných zkušeností můžete využít v běžném životě? Jaké překážky vám $v$ životě budou bránit $v$ tom, abyste nově získané zkušenosti mohli využít v běžných životních situacích? Co potřebujete ještě pro to, abyste dokázali efektivním způsobem nově získané zkušenosti zakomponovat do běžného života? apod.

Uvedený návod postupu, který umožňuje systematické směrování otázek v reflexi u technik pedagogického procesu osobnostního a sociálního rozvoje, je z obecného hlediska obdobný námi už popsaného modelu Greenawae. Postup Švece nabízí podrobnější schéma doplněné o složky zachycující první dojmy účastníků z realizované techniky a skupinovou dynamiku, jež se v ní odehrály. 
V odborné literatuře (např. Hermochová, 1982, 1988; Valenta, 2000, 2006; Franc \& Zounková, Martin, 2007; Pelánek, 2008) bychom mohli najít mnoho dalších námětů, jak cíleným a efektivním způsobem realizovat reflexe.

V souvislosti s problematikou reflexí, je rovněž třeba si uvědomit, že studenti, které nemají dostatečné zkušenosti s technikami osobnostního a sociálního rozvoje, nechtějí často hovořit před celou skupinou. $Z$ tohoto důvodu je rozumnější využívat rozmanitějších forem reflexí jako např. kresebné či písemné vyjádření, diskuse v malých skupinách atd.

\section{Evaluace}

Dalším důležitým krokem v realizaci výukového programu je cílené a systematické měření jeho efektivity. Tento krok vychází z pojetí, že každý kurz osobnostního rozvoje je nutno nejen naplánovat, ale také systematicky kontrolovat, vyhodnocovat a na základě zpětné vazby flexibilně regulovat. Uvedenou skutečnost potvrzuje Hermochová, (In Komárková, Slaměník, \& Výrost, 2001, s. 191) která uvádí, že účinnost výcvikových programů je možné určit prostřednictvím hodnocení, evaluace. Jedná se o proces zjištování, zda určité aktivity vedly k očekávaným důsledkům.

Jarošová (In Komárková, Slaměník, \& Výrost, 2001, s. 192) uvádí, že ověřování efektivity výukových programů je přínosné pro studenty, kteří se osobnostního rozvoje účastní, pro pedagogy i pro vzdělávací instituce (fakulty vzdělávající budoucí učitelé), které výcvik organizují. 
1. Prínos pro studenty:

Př́nos pro studenty, kteří se zúčastnili výukového programu osobnostního rozvoje, Ize popsat v několika rovinách:

$\rightarrow$ záměr provést hodnocení zpravidla vede $k$ důkladnější obsahové prrípravě výuky a k jeho užší vazbě na potřeby studenta,

$\rightarrow$ sami studenti mohou být více ,,vtaženi“ do př́pravy výuky a specifikace jeho cílů,

$\rightarrow$ použití hodnotících nástrojů je pro studenty príležitostí získat dostatečnou zpětnou vazbu i sledovat svůj osobní rozvoj.

2. Prínos pro pedagogy:

Pedagogům poskytuje hodnocení zpětnou vazbu a dává jim podněty pro zvýšení účinnosti pedagogického procesu. Na základě výsledků mohou zpřesňovat svoji práci při koncipování výukového programu a volbě metod osobnostního rozvoje.

3. Prínos pro vzdělávací instituce:

Závěry o efektivitě výuky mohou sloužit jednak vysoké škole, která realizaci osobnostního rozvoje organizuje a sama si chce ověřit, zda vynaložené prostředky byly použity účelně, nebo pro prezentaci širší odborné obci. Údaje slouží jako podklady pro výzkumnou práci v odborných kruzích.

V odborné literatuře (např. Hermochová, 1988; Komárková, Slaměník, \& Výrost, 2001) se uvádí, že hodnocení je zpravidla nejslabším článkem učebního cyklu. Jen velmi málo výukových programů je hodnoceno systematicky. Často je evaluační hodnocení opomíjeno i tam, kde by mělo hrát významnou roli. Jednou z prríčin tohoto stavu je pravděpodobně náročnost hodnocení - at' 
už z hlediska časového, finančního či metodologického.

Podle našeho názoru má hodnocení programů osobnostního rozvoje nesporný význam. Díky tomu můžeme najít odpověd’ na následující otázky:

Došlo v průběhu a po skončení výukového programu k žádoucím změnám v osobnostních a sociálních dovednostech účastníkư?

Měl výukový program pozitivní vliv na rozvoj vztahů ve studijní skupině?

Byly pro dosažení stanovených cílů zvoleny správné organizační formy a metody?

Jaké konkrétní zkušenosti získali studenti prostřednictvím výcvikového programu?

Jak dalece dokáží studenti nově získané zkušenosti ve výukovém programu osobnostního rozvoje využít v reálném životě a budoucí učitelské profesi?

Určitě bychom našli ještě mnoho dalších otázek, které by se týkaly účinnosti výukových programů.

K dosažení relativně objektivních údajů při ověřování efektivity výukového programu se používá velká škála výzkumných metod. Mezi nejčastěji používané metody patří např. řízená diskuse, dotazník, rating, osobnostní testy, sociometrie apod. Aby uvedené metody plnily svoji funkci, musí se aplikovat prostřednictvím evaluačního modelu. Jarošová (In Komárková, Slaměník, \& Výrost, 2001, s. 192) uvádí několik evaluačních modelů, které se od sebe liší v náročnosti využití ve výukovém programu a přesností získaných údajů. Všechny evaluační modely mají společné to, že se snaží 
o zaznamenání účinku výukového programu na více úrovních, nebot' při komplexnosti sledovaných jevů by soustředění se pouze na některou oblast (např. postižení změn v chování) mohlo být zavádějící či zkreslující.

Domníváme se, že pro výukové programy osobnostního rozvoje realizované na vysokých školách jsou vhodné následující evaluační modely, které se dají snadno aplikovat, a přitom umožňují získat relativně velký soubor cenných informací:

$\rightarrow$ Model ,jednoho měření“

Tento model se v praxi velmi často využívá, i když se nejedná o evaluační model výzkumného charakteru. Jedná se o postup, kdy se sběr dat pro hodnocení provádí pouze u jedné studijní skupiny po absolvování výukového programu. Je možné jej vyjádřit následujícím schématem:

\section{Výcviková skupina: I (intervence) $\rightarrow M$ (měření)}

Pedagog po realizaci výukového programu uskuteční jedno měření, například provede rozhovory s jeho účastníky, předloží jim postojovou škálu či provede pozorování při činnosti. Je nepravděpodobné, aby tento model přinesl platné a spolehlivé výsledky. Pokud je neznámá vstupní úroveň účastníků, není možné s jistotou stanovit, že př́znivé výsledky v období po výuce osobnostního rozvoje byly způsobeny právě realizací programu. I přes tyto nevýhody má tento model ve vysokoškolské výuce časté využití. Vždyt' cílem ověřování efektivity těchto výukových programů není realizování výzkumných projektů, ale relativně jednoduchý sběr údajů, který by nenarušoval průběh výuky a zbytečně nezatěžoval svoji náročností na vyplňování evaluačních nástrojů samotné studenty. 
$\rightarrow$ Model „dvou měřeni“"

Přesnějším, ale náročnějším na aplikaci ve výukovém programu je model ,jedna skupina, dvě měření“. $V$ tomto modelu provede pedagog jedno měření hodnot zvolených proměnných na začátku a jedno na konci učebního procesu:

\section{Výcviková skupina}

\section{$M$ (měření, „pretest") $\rightarrow$ I (intervence, tj. výcvik) \\ $\rightarrow M$ (měření, ,posttest")}

Výhodou je jednoduchost tohoto postupu. Nevýhodou je neprůkaznost výsledků hodnocení, nebot' zaznamenané pozitivní změny v proměnných není možné připsat jednoznačně realizovanému programu osobnostního rozvoje.

Z výše uvedených evaluačních modelů je zřejmé, že hodnocení účinnosti sice patří mezi poslední fáze pedagogického procesu, ale to neznamená, že ho Ize odkládat až na závěr práce se skupinou. Evaluační projekty jsou zároveň součástí úvodních fází osobnostního rozvoje, ve kterých se formulují cíle, zjišt'ují očekávání účastníků a analyzují se vstupní proměnné jako je např. dosavadní stupeň získaných osobnostních a sociálních dovedností, aktuální sociální klima ve studijní skupině apod.

V kurzech osobnostně sociálního rozvoje se využívají techniky / hry, které je možné rozdělit do následujících oblastí: 


\subsubsection{Uvolňovací a zahřívací herní aktivity/techniky}

\section{"Icebreakers"}

Techniky, které mají napomoci prolomit pomyslné bariéry mezi žáky a přivést je k vzájemnému kontaktu. Slouží zároveň jako „přechodový rituál“ k učení založeném na vlastní aktivitě - fyzické i mentální. Ladí skupinu na stejnou „vlnu,“ dostávají je do pohybu a zbavují ostychu. Patři sem techniky s jednoduchými pravidly, jednoduchým dějem, často veselé a uvolňující.

Ukázka některých technik:

\section{$\rightarrow$ Seznamování s pomocí balónku}

Hráči sedí v kruhu. Jeden obdrží balónek, který hodí jakémukoliv dalšímu hráči. Ten, jakmile jej chytí, řekne hned své křestní jméno a hází balónek dalšímu, ten opět chytí a řekne své jméno. Až se vystrí́dají v chytání všichni, házení pokračuje, ale tentokrát ten, který hází, říká jméno toho, komu hází. Pokud házející neuhodne, špatně oslovený hráč balónek chytí a hází beze slova zpět mýlícímu se hráči. (Valenta, 2000, s. 39)

\section{$\rightarrow$ Místa si vymění}

Hráči s výjimkou jednoho se sesednou v kruhu na židle. Zbývající hráč stojí uprostřed a rríká: „Místa si vymění ti, kteří..." a doplní konkrétní společnou věc. Ze židlí se zvednou všichni hráči, na které výrok platí, a snaží se posadit na jinou uvolněnou židli. Stejnou snahu má i hráč, který byl původně ve středu kruhu. Tak se na jeho místo dostane jiný hráč, na kterého židle nezbyla, a hra pokračuje. (Valenta, 2000, s. 39) 


\section{$\rightarrow$ Jmenné tchai-t'i}

Hráči stojí v kruhu a na principu postupného řetězení vytvoří „,taneční“ řadu. Každý postupně přidává své jméno s adjektivem začínajícím na stejné písmeno a doplněném o výraznou fyzickou pózu. Podmínkou je, aby nová póza vycházela z té předchozí. Následně je možné společný tanec opakovat s různými zadáními (rychlost, omezení pohybu, řeči apod.).

\section{„Warm-Ups“ - zahřívací techniky, navozující společný prožitek ve skupinĕ}

Po úvodních technikách mohou být zahájeny aktivity, ve kterých už dochází mezi účastníky poprvé k většímu bezprostřednímu tělesnému kontaktu. Informace se v prvé fázi mohou předávat formou „mluvy těla,“ neverbální komunikací. Zdůrazňuje se zde činnost celé skupiny, zapojení každého jednotlivce pomocí tradičních a netradičních přístupů. Budují se zde první základy pro vzájemnou důvěru. Herní aktivity, ve kterých dochází k častému tělesnému kontaktu, vyžadují vstřrícný přístup jednotlivce k ostatním členům skupiny. Toho se dá dosáhnout jen tak, že se hráči zapojí do hry dobrovolně. Na každém pak záleží, jaký odstup či blízkost bude při hrách vyžadovat. Proto je třeba k mnohým účastníkům přistupovat s pochopením a trpělivostí a dát jim čas, aby získali své vlastní pozitivní zkušenosti.

Ukázka některých technik:

\section{$\rightarrow$ Tanec na kládě}

Vybídneme skupinu, aby se postavila na kládu v libovolném pořadí. Účastníci se premist’ují tak, aby vytvořili řadu, ve které budou seřazeni 
abecedně podle prvního písmena křestního jména. To znamená, že první vlevo bude stát např. Adam a vpravo na konci bude Zora. Po celou dobu přesouvání musí zůstat celá skupina na kládě. Každý dotyk země bude penalizován nebo se celá skupina vrátí zpět do výchozího postavení. (Neuman, 1998, s. 56)

\section{$\rightarrow$ Hmota}

Všichni hráči si zavážou oči a pohybují se v určitém území. Jednoho $z$ nich lektoři vyberou a stanoví ho dotykem na rameno jádrem „Hmoty." Jeho úkolem je pomalý pohyb v území a zachování mlčenlivosti. Ostatní hráči se pohybují, nemluví a snaží se „Hmotu“ dotykem objevit. Dotkne-li se hráč hráče, zeptá se „Hmota?“ Všichni hledající hráči reagují na dotaz odpovědí „,Hmota?“" Jen hráč, který představuje jádro „Hmoty,“ neodpovídá. Hráč, který hledanou „Hmotu“ nalezl, se k ní připojí. Pak se pohybují prostorem ve dvojici. Hra pokračuje dále a skončí, až se všichni hráči stanou součástí „Hmoty,“ drží se společně za ruce a pomalu se pohybují. Hru ukončí lektor. (Neuman, 1998, s. 77)

\section{$\rightarrow$ Hry na babu}

Na všechny možné způsoby (ideálně modifikované podle tématu lekce). 


\subsubsection{Herní aktivity/techniky zaměřené na sebepoznání}

Proces sebepoznání jako jedna z důležitých podmínek efektivního procesu rozvoje osobnostních a sociálních předpokladů je obsahem všech typů technik pedagogického procesu osobnostního a sociálního rozvoje. Nicméně považujeme za důležité do výukových programů zařazovat takové techniky, které jsou na problematiku sebepoznání cíleně zaměřené a umožňují „odkrývat“ člověku vnitřní pohnutky, jež ovlivňují jeho individuální projevy v chování a prožívání.

\section{Techniky zaměřené na sebereflexi vlastního chování a prožívání}

Tento typ technik umožňuje účastníkovi vyjádřit sám sebe na principu projekce svých přirozených osobnostních vlastností do výtvarného, slovního či hudebního projevu. Jedná se o vhodný a nenásilný prostředek, který umožňuje člověku uvědomit si některé aspekty své osobnosti, např. dominantnost - submisivitu, extraverzi - intorverzi, emoční ladění, svou hodnotovou orientaci a své postoje. Předností uvedených technik je to, že se člověk při nich projevuje spontánně s minimálním množstvím naučených a cvikem získaných vzorců chování. Mezi další prostředky poznávání svých osobnostních vlastností patří celé spektrum osobnostních dotazníků a testových metod, jež se mohou využívat ve vzdělávání a nejsou určeny pouze pro klinickou praxi.

Ukázka některých technik:

\section{$\rightarrow$ Tvorba erbu}

Každý účastník si z různých materiálů vytváríi svůj vlastní erb, který se vztahuje k zadání: To jsem JÁ. Po dokončení všech erbů následuje 
jejich výstava, kdy každý má možnost prezentovat na jednotlivých dílech své postřehy, podněty, vnímání výpovědi dílka, co asi říká, jak pưsobí erb jako celek. Poté autor může, ale také nemusí vysvětlit, proč vytvořil to či ono, co znamená erb a proč využil právě tyto symboly a barvy. (Neuman, 1998, s. 67)

Techniky zaměřené na poznání svých vlastních projevů v interakci s druhými

Tyto techniky mají poskytnout účastníkům informace o tom, jak a podle čeho je vnímají druzí. Každý účastník poskytuje druhým informace o své osobě, které se opírají:

$\rightarrow \quad 0$ jeho chování: jedná se o nejvýznamnější zdroj informací, které druhým poskytuje. Problém je však v tom, že z vněǰš́ stránky projevu není vždy možné soudit na vnitřní zdroje člověka (postoje, motivy, prríčiny). Mnohdy si ani tyto vnitřní zdroje jedinec sám neuvědomuje.

$\rightarrow \quad 0$ jeho verbální projev: jedná se o velmi významný zdroj, který může být přijímán ostatními rozdílně (člověk je přijímán kladněji, když má tendence se jevit ve společensky žádoucím světle, např. říká to, co všichni rádi slyší, co je skupinou obecně přijímáno).

$\rightarrow \quad 0$ tzv. neverbální klíče: jedná se o celou řadu vnějších pozorovatelných rysů druhými, kterými se jedinec prezentuje, ale většinou si tyto rysy neuvědomuje. Někdy může dojít k rozporu mezi verbálními a neverbálními projevy, např. při neupř́mnosti, obavách apod. 
Ukázka některých technik:

$\rightarrow$ Posouzení osoby na základě jednorázové výpovědi Jeden z účastníků předstoupí před skupinu a po dobu 2 min hovoří na libovolné téma. Spoluhráči tuto osobu poslouchají a poté vyjadřují své dojmy z toho, jak na ně tato osoba v průběhu vystoupení působila. (Hermochová, 2004, s. 30) 


\subsubsection{Herní aktivity/techniky zaměřené na rozvoj základních osobnostních, sociálních a morálně - existenčních předpokladů}

\section{Techniky zaměřené na rozvoj osobnostních předpokladů}

Jedná se o soubor technik, které se zaměřují na rozvoj psychického potenciálu jedince v oblasti základních psychických jevů, tzn. psychických procesů, psychických stavů, psychických vlastností a dílčích psychických předpokladů. Tyto psychické atributy v osobnosti člověka jsou klíčovými faktory ovlivňujícími jeho úspěšnost v různorodých činnostech jako je např. učení, tvořivé způsoby řešení problémů apod. Techniky spadající do tohoto tematického okruhu mají spíše charakter objevování, nácviku, procvičování, zdokonalování jednotlivých složek psychického obsahu jedince.

Techniky zaměřené na rozvoj psychických procesů (vnímání, představ, myšlení apod.)

Do této skupiny patří techniky, jež rozvíjejí široké spektrum osobnostních předpokladů, od zdokonalování jednotlivých smyslů, přes zlepšování pamětových schopností, postupů při řešení intelektových úloh a konče cvičením rozvoje senzomotoriky. Jen málokterá technika prověřuje a cvičí jen jedinou ze zmiňovaných stránek psychické výbavy člověka. Většinou se při nich uplatní celá řada vlastností a dovedností, některé ve větší, jiné v menší míře.

Ukázka některých technik:

\section{$\rightarrow$ Poznej po hmatu}

Účastníci se posadí kolem stolu tak těsně, aby neviděli na své ruce, které mají pod deskou na kolenou. Pedagog zaujme místo v čele 
stolu, vytahuje z krabice postupně nejrůznější předměty (např. knoflík, kousek látky, korunovou minci, kolíček na prádlo, kostku cukru, krabičku od zápalek, pecku z broskve atd.) a podává je v kratších nebo delších intervalech tomu, kdo sedí po jeho levici. Hráč předmět pod deskou pozorně ohmatá a předá ho sousedovi po levé ruce. Předmět pak obejde celý stůl, aniž by ho kdo spatřil, a vrátí se k pedagogovi lektorovi, který ho uloží zpátky do krabice. Když se vrátí poslední z kolujících věcí, jsou žáci vyzváni, aby si vzali papír a zapsali všechny předměty, které poznali. (Zapletal, 1996, s. 99)

\section{$\rightarrow$ Na hononyma}

Jeden účastník odejde na chvíli za dveře. Ostatní se domluví na slově, které má několik různých významů. Např. to bude „roh“ nebo „los“, „koza“, „,koleno“, „list“, „,kohoutek“, „kolej“, ,kmen“, „žába“ apod. Potom zavolají hráče zpátky a ten jim postupně položí tři otázky: 1. Jaké to je? 2. Kde to najdu? K čemu to je?

Na každou otázku odpovídají studenti po řadě a snaží se ho zmást zcela protichůdným avšak pravdivým tvrzením. Např. při smluveném heslu „los“ budou na první otázku odpovídat: Papírové, živé, neživé, pohyblivé, nepohyblivé, velké, malé, parohaté apod. Na druhou otázku mohou odpovědět: Na polárním kruhu, v tundře, ve spořitelně, $v$ zoologické zahradě, u pouličního prodavače. Na třetí otázku řeknou: Na získání peněz, k lovu, na vylákání desetikoruny od kolemjdoucích. Když účastník z těchto odpovědí vydedukuje, že skupina se smluvila na pojmu „los,“ kterým je pojmenováno jednak zvíře, jednak číslovaná poukázka loterie, vítězí. V další hře ho vystřídá někdo jiný. (Zapletal, 1996, s. 99) 
Techniky zamřené na rozvoj psychických stavů (pozornosti, emocí)

Techniky zaměřené na rozvoj stavů pozornosti a citových stavů tvoří samostatnou podskupinu i přesto, že úzce souvisejí s technikami zaměřenými na rozvoj ostatních psychických jevů v osobnosti člověka (např. vnímání, myšlení, způsoby řešení logických nebo sociálních situací apod.). Psychické stavy jsou jednou ze složek osobnosti člověka, která v období dětství a dospívání prochází značnými kvantitativními a kvalitativními změnami. $Z$ tohoto důvodu se v pedagogice osobnostního a sociálního rozvoje využívá mnoho různorodě pojatých technik, jež jsou zaměřeny na adaptaci psychických stavů, efektivní vykonávání činností (např. schopnost koncentrace) a nebo na vyjadřování pocitů libosti, nelibosti, preferování, odmítání apod.

Ukázka některých technik:

\section{$\rightarrow$ Korektoři}

Je nutné opatřit tolik kopií libovolného textu, kolik je studentů. $Z$ textu se vybere určitá část, asi třicet až čtyřicet řádků, a řekne se všem, aby udělali tečku pod každým „m,“ „M,“ a dali do kroužku každé „,k,“ „K.“ Kdo je hotov, odloží tužku a pedagog mu zapíše dosažený čas. Za každou chybu - písmeno neoznačené nebo označené nesprávně - se připočítává pět sekund. (Zapletal, 1996, s. 99)

\section{$\rightarrow$ Masážní řetěz}

Studenti sedí v kruhu otočení zády $k$ sousedovi po levé straně (opěradlo židle je na vnější straně), a to $v$ takové vzdálenosti, aby na sebe snadno dosáhly. Účastníci jsou vyzváni, aby jemně masírovali ramena spolužáka, který sedí před nimi. Cílem je dosáhnout u kolegy př́ijemného pocitu uvolnění. Aby bylo možné sledovat, zda kolega 
prožívá masáž jako příjemnou, masírovaný dává různými zvuky (nikoliv slovy) najevo, zda je mu masáž př́ijemná, či nikoli. Každý vysílá zvuky dozadu a zároveň dává pozor na signály, které dostává zepředu. (Hermochová, 1994, s. 24) 


\subsubsection{Herní aktivity/techniky zaměřené na rozvoj sociálních předpokladů}

Soubor těchto technik je orientován na rozvoj elementárních sociálních předpokladů osobnosti, které jsou potřebné pro styk s lidmi. Můžeme říci, že tyto předpoklady tvoří osobnostně sociální profil jedince, který se projevuje ve schopnosti taktického jednání s druhými a vycházení s nimi. Znamená to, že níže popisované podskupiny technik podněcují k rozvoji všechny složky osobnosti člověka související s mezilidskou komunikací.

\section{Techniky zaměřené na poznávání druhých}

Hlavním záměrem technik zaměřených na poznávání druhých je výcvik v sociální percepci, již můžeme vymezit jako formování soudů o jiných lidech. $V$ pedagogickém procesu osobnostního a sociálního rozvoje se za pomoci těchto technik snažíme proniknout do procesu vytváření dojmů o jiných lidech, zabývat se spolehlivostí jednotlivých informačních zdrojů, validitou percepčních soudů, interindividuálními rozdíly ve schopnosti adekvátně odrážet personální okolí aj. Techniky tedy přispívají k celkovému osvětlení procesu vnímání druhých osob, které je založeno na třech základních složkách:

$\rightarrow$ Atributivní složka - základem formování dojmu o druhé osobě je to, že jí přičítáme určité vlastnosti, a to vnější i vnitřní.

$\rightarrow \quad$ Očekávací složka - percepce osob není jen přičítáním určitých vlastností, ale zahrnuje i celou řadu očekávání ze strany toho, kdo poznává druhé. Tato očekávání jsou často nevědomá 
a registrujeme je, pokud se nevyplní. Očekávání ovlivňuje hlavně vstupující informaci, tj. čeho si na druhé straně všímáme. Často se zaměřujeme na to, co od osoby potřebujeme, a ne na to, jaká je.

$\rightarrow$ Afektivní složka - emocionální reagování ovlivňuje naše soudy o druhém jedinci jednak tím, že ovlivňuje náš dojem, který si na základě určitých informací vytvoříme, a jednak tím, že je jedním z faktorů, na jejichž základě provádíme selekci informací, kterých si všímáme.

Ukázka některých technik:

\section{$\rightarrow$ Intuice}

Účastníci se rozdělí do skupin. Důležité je, aby se účastníci ve skupině př́liš dobře neznali (neměli o sobě podrobné informace). Účastníci se pokouší odhadnout správné odpovědi na několik otázek (maximálně 10) týkajících se někoho z členů skupiny, konkrétní osoby (např. jejích zájmů, vlastností, přání apod.). V roli odhadované osoby se všichni členové skupiny postupně vystřídají.

Skupině se opakovaně zdůrazňuje, že nejde o body či správné odpovědi, ale o zachycení toho, co našemu odhadu druhého pomáhá, co jej ovlivňuje a spoluvytváríi. Není totiž cílem provést správný odhad, ale porozumět tomu, co mě k tomuto odhadu přivedlo, a rovněž tomu, co je pro moje osobní odhady příznačné, čeho si nejčastěji všímám, $v$ čem si jsem jistý, kde mám naopak rezervy a jak celý proces funguje.

$\rightarrow$ Typy otázek

$\rightarrow$ Rád poslouchám: a)...b)...c)...

$\rightarrow \quad$ Nejraději čtu: a)...b)...c)...

$\rightarrow$ Mezi mé zájmy patř́i: a)...b)...c)... 
$\rightarrow \quad$ Moje oblíbená barva je: a)...b)...c)...

$\rightarrow$ Prázdniny nejraději trávím: a)...b)...c)...

$\rightarrow$ Chtěl bych vykonávat povolání: a)...b)...c)...

$\rightarrow$ Mezi mé oblíbené předměty patř́i: a)...b)...c)...

$\rightarrow$ Obvykle mám strach, když: a)...b)...c)...

$\rightarrow \quad$ U kamaráda si vážím: a)...b)...c)...

$\rightarrow$ Kdybych se po druhé narodil, chtěl bych žít: a)...b)...c)... (Štětovská In Komárková, Slaměník, \& Výrost, 2001, s. 37)

\section{Techniky zaměřené na neverbální komunikaci}

Tyto techniky umožňují rozvíjet, ale také pochopit význam a důležitost neverbálních signálů v lidské komunikaci. Neverbální signály mají v lidské komunikaci různý smysl a účel. Podle toho je můžeme dělit:

$\rightarrow$ Symboly, které mohou být př́mo přeloženy do slova či slov v rámci konkrétně užívané významové oblasti (např. zdvižený palec = „jde to skvěle“, ukazováčky kolmé na sebe = „,technická chyba“);

$\rightarrow \quad$ llustrátory, které provázejí mluvené slovo. Používá se jich pro zdůraznění a dosažení významu a smyslu slova.

$\rightarrow$ Regulátory, tj. usměrňující a řídící signály, které často slouží k přerušení nebo ukončení komunikace (např. kývání hlavou, podání ruky, významný pohled do očí aj.).

$\rightarrow$ Adaptéry, tj. pohyby, gesta používaná pro zvládnutí našich pocitů a k řízení našich reakcí ve stresových situacích (např. kousání nehtů, tahání za ušní lalůčky, hlazení vousů aj.). 
V souvislosti s neverbálními projevy se často hovoří o tzv. metakomunikaci, o mimoslovních sděleních, kterými vyjadřujeme, jak je třeba chápat mluvenou řeč (zda vážně či žertem), je to vlastně „sdělení o sdělení“. Významně doplňuje mluvenou řeč, zejména vyjadřuje citový vztah mluvčího.

Ukázka některých technik:

\section{$\rightarrow$ Čím jsem}

Jeden dobrovolník odejde z místnosti. Ostatní hráči vyberou dobrovolníkovi nějakou profesi (například ošetřovatelka, učitel, klaun, prodavač atd.; měla by to být činorodá profese nebo profese, která prezentuje nějaký typ instituce či úřadu). Následně je zavolán dobrovolník zpět a posadí se doprostřed místnosti. Ostatní se pak jednotlivě nebo $v$ malých skupinách začnou v blízkosti dobrovolníka zabývat odpovídající činností na principu neverbálních výrazů. Hra končí $v$ okamžiku, kdy dobrovolník tím, co říká nebo dělá, prokáže, že poznal, jaká profese mu byla vybrána. (Hickson, 2000, s. 72)

\section{Techniky zaměřené na verbální komunikaci}

Skupina technik, která je zaměřena na verbální komunikaci, umožňuje účastníkům rozvinout základní verbální prvky lidské komunikace. Pomocí různorodých aktivit si jedinec osvojí dovednosti, jež se týkají úrovně prezentace jeho myšlenek, názorů, postojů a hodnot.

Ukázka některých technik:

\section{Hyde park (rétorické fórum)}

Ze skupiny vylosujeme několik řečníků. Jejich úkolem bude na improvizované tribuně (ostatní sedí nebo stojí) přednést tříminutový projev 
na libovolné téma (může si vybrat sám nebo vylosovat). Posluchači mohou vstupovat svými dotazy a je na mluvčím, jak na ně zareaguje. Obměna: Řečníci prezentují svůj projev, ve kterém převládá jeden z percepčních stylů (vizuální, auditivní, kinestetický).

\section{Techniky zaměřené na rozvoj komunikace ve skupině}

Tyto techniky se zaměřují na nácvik komunikace ve skupině. V každé sociální skupině se uskutečňuje mezi členy dialog či diskuse, jež se vztahují ke způsobu řešení běžných i složitých skupinových úkolů. Přitom je nutné, aby členové skupiny dokázali vznášet a prezentovat své návrhy, vyslechnout ostatní a akceptovat názor druhých. Cílovým stavem každé skupinové diskuse by měl být stav konsensu, kdy všichni členové skupiny mohou akceptovat závěr (výsledek, zvolenou možnost) diskuse. Aby ke konsensuálnímu stavu skupina došla, musí se každý účastník chovat zodpovědně a disciplinovaně ve vztahu k sobě i ve vztahu k druhým. Znamená to umět respektovat názor druhých, ale nebát se prosazovat sám sebe a svá stanoviska. Uvedené osobnostní předpoklady jsou rozvíjeny celou řadou technik, které jsou zaměřeny na nácvik asertivního chování.

Ukázka některých technik:

\section{$\rightarrow$ Sponzorský dar}

Účastníci jsou rozděleni do skupin. Každá skupina obdrží text s názvem „Sponzorský dar." Cílem skupiny je dohodnout se na jednom z možných řešení.

Sponzorský dar - předložený text: 
Vaše skupina obdržela od anonymního sponzora 300000 Kč. Vašim úkolem je se domluvit, jak peníze utratíte. Vyberte si jedno z řešení, která jsou uvedena dole. Každé rozhodnutí je v ceně celých 300000 Kč. Můžete tedy zvolit jen jedno z nich. Pokud se skupina nebude moci rozhodnout, jak peníze utratit, celá částka bude vrácena sponzorovi.

\section{$\rightarrow$ MOŽNOSTI:}

$\rightarrow$ Skupina pojede na zahraniční cestu.

$\rightarrow$ Věnujete peníze fakultní organizaci, pomáhající studentům, kteří mají sociální problémy.

$\rightarrow$ Každý student obdrží týdně 1000 Kč až do doby, kdy budou peníze vyčerpány.

$\rightarrow$ Nakoupí se IT technologie do učeben.

$\rightarrow$ Zaplatíte vaší nejoblíbenější hudební skupině a uspořádáte na fakultě její koncert.

$\rightarrow$ Budete sponzorovat nemocnici, která se zabývá léčením rakoviny.

\section{$\rightarrow$ Př́padová studie}

Studenti mají ztvárnit řešení konfliktní situace, která může ve skupině nastat nebo se často stává, např. nedodržování stanovených pravidel, zesměšňování druhých, agresivní prosazování individuálních stanovisek apod. Řešení probíhá ve dvojicích či trojicích za podpory pedagoga-lektora. (Vališová, 2002, s. 265) 


\subsubsection{Herní aktivity/techniky zaměřené na rozvoj morálně - existenčních předpokladů}

Tento soubor technik naplňuje jedno z důležitých témat pedagogického procesu osobnostního a sociálního rozvoje: morální vědomí, hodnoty a životní cíle. Techniky poskytují žákům vhled do oblastí týkajících se pochopení vlastního zpưsobu života, vytváření hodnotových priorit, stanovování si životních cílů a celkového způsobu morálního chování k druhým. Součástí této skupiny technik je nácvik empatie a jednání, jež je v souladu s principy prosociálního chování.

\section{Techniky zaměřené na prosociálního chování}

Tyto techniky posilují výskyt prosociálního chování jedince, které Ize považovat za projev správně orientovaného morálního rozvoje. V technikách se pracuje s takovými podobami chování, jako je např. soucítění, solidarita, pomoc potřebnému atd. Současně se žáci naučí rozlišovat projevy chování, které mají charakter prosociálnosti, a které ne.

Ukázka některých technik:

\section{$\rightarrow$ Zmrzlé ruce}

Hráči se rozdělí do dvojic s někým, koho méně znají a chtěli by ho poznat lépe. Sednou si proti sobě. Představují si, že jeden z dvojice byl dlouho venku za mrazivé zimní noci a má zcela prochladlé ruce. Chlad odstraníme plet’ovým mlékem, které je třeba opatrně vetřít do rukou. Pečující hráč si kápne pár kapek do dlaně a jemně je vtírá do „zmrzlých“ rukou svého společníka. Po přiměřeně dlouhé době si oba vymění role. (Hermochová \& Neuman, 2003, s. 28) 


\section{$\rightarrow$ O hodném strážci majáku}

Studentům je prezentován následující příběh:

Na jednom ostrově obsluhoval maják velmi hodný a ústupný chlapík. S každým chtěl vycházet dobře a nikomu neuměl ríct ne. Jednou za čas dostával z královských zásob láhev vzácného oleje, aby měl čím plnit strážnou lampu. Nebe bylo jasné a moře poklidné. Zrána přišla za strážcem majáku stará vdova. „Ulej mi kapku oleje,“ prosila ho. „Bliží se výročí smrti mého muže, musím mu zapálit věčné světlo, aby jeho duše spočívala v míru. "Strážce jí ulil oleje a vdova zajásala: „Ach, ten náš strážce, ten má srdce ze zlata!" V poledni přišel za strážcem majáku soused. „Příteli, že mi dáš kapičku oleje? Musím naolejovat své stroje, jinak bych dnes prišel o výdělek." Dostal svou sklenku oleje a nadšeně strážce majáku objal: „Vždyt' já věděl, že jsi kamarád!“ $K$ večeru přiběhla mladá matka a moc naříkala: „,Mé dítě, mé drahé dětátko se spálilo a křičí! Prosím tě, ulej mi oleje a já mu budu mazat bolístku!" I jí strážce odlil vzácný olej. Žena mu vroucně políbila ruku: „To je ale štěstí, že tu hlídá maják někdo tak hodný jako ty!" V noci přišla strašná bouře. Strážce spěchal na maják rozsvítit lampu. Ale oleje už bylo sotva na dně. Lampa zhasla. Lod' se stovkami lidí na palubě narazila do skal a všichni do jednoho utonuli v moři. Nikde $v$ celém širém světe nebyl tak hodný stráčce majáku.

Po přečtení př́běhu následuje diskuse:

Souhlasíte s tím, že strážce byl hodný a laskavý člověk? Byl empatický? Byl oblíbený? Přesto cítíme, že něco bylo špatně. Co? Proč byl špatným strážcem majáku? Bylo jeho chování prosociální? (Fišerová In Vacek, 2008, s. 80) 


\section{Techniky zaměřené na řešení morálního dilematu}

Rozhodování se v situacích majících morální aspekt je jednou z velmi užívanou aktivitou $v$ programech pedagogického procesu osobnostního a sociálního rozvoje. $V$ jednotlivých skupinách (dle věku, sociálního zázemí, individuálních vlastností) můžeme u studentů zaznamenávat rozdílné úrovně a stádia morálního rozhodování, které L. Kohlberg rozděluje do tří základních skupin:

$\rightarrow$ Prekonvenční úroveň

$\rightarrow \quad$ Konvenční úroveň

$\rightarrow$ Postkonvenční úroveň

L. Kohlberg jednotlivé úrovně charakterizuje takto: „Předkonvenční morální úroveň je úrovní většiny dětí do 9 let, některých adolescentů a mnoha dospívajících a dospělých kriminálních živlů. Konvenční úroveň je úrovní většiny adolescentů a dospělých v naší společnosti i ostatních společnostech. Postkonvenční úrovně dosahuje menšina dospělých, obvykle teprve po 20. roce života." (Kohlberg In Vacek, 2008, s. 26)

Ukázka některých technik:

\section{$\rightarrow$ Davidovo dilema}

Studentům je prezentován následující příběh:

Čtrnáctiletý David velmi toužil jet na víkend s kamarády. Otec mu to slíbil za předpokladu, že si na výlet sám ušetří. David se snažil a pilně sbíral starý papír a jiné suroviny. Za měsíc a půl vydělal tolik, že mohl na plánovaný výlet jet. Těsně před víkendem však otec změnil názor. Jeden z přátel ho pozval na vyjížd'ku spojenou s chytáním ryb, jenže otec měl momentálně málo peněz, a tak se obrátil na syna 
a požádal ho, aby mu vydělané peníze pưjčil. David nechtěl přijít o víkend s kamarády a přemýšlel, zda má otcově žádosti vyhovět, nebo ji odmítnout.

Po přečtení př́běhu následuje diskuse:

Měl by David otci peníze půjčit? Proč ano, proč ne? Měl otec právo chtít po něm peníze? Proč ano, proč ne? Je v tomto príběhu důležité, že si chlapec peníze vydělal sám? Proč ano, proč ne? Je důležité, že otec synovi dovolil jet na víkendovou akci, pokud si na ni vydělá? Proč ano, proč ne? Obecně vzato - proč by měly být sliby dodržovány? (je důležité dodržet slib?) Je stejně důležité dodržet slib někomu, koho dobře neznáte a možná ho už nikdy neuvidíte? Proč ano, proč ne? Jaká je nejdůležitější věc, na kterou by měl syn ve vztahu k otci dbát? Proč je to nejdůležitější věc? A jaká je nejdůležitější věc, na kterou by měl dbát otec ve vztahu $k$ synovi? Proč? Když se nad př́iběhem zpětně zamyslíte, v čem spočívá Davidova největší odpovědnost? Proč? (Vacek, 2008, s. 39)

\section{Techniky zaměřené na uvědomění si vlastních hodnot a životních cílů}

Techniky z tohoto bloku si kladou za cíl podněcovat studenty k tomu, aby si uvědomili a dokázali stanovit životní cíle krátkodobého a dlouhodobého charakteru a zároveň si uměli určit prostředky $\mathrm{k}$ jejich dosažení. S uvedenou problematikou jsou úzce spojeny aktivity, ve kterých účastníci analyzují, zhodnocují a potvrzují své směřování k určitým hodnotám. Mezi další dưležité osobnostní předpoklady pro dosahování stanovených cílů je schopnost člověka dodržovat režimovou stránku dne. V technikách osobnostního a sociálního rozvoje si studenti mohou naučit zvnitřňovat takové principy, jako jsou např.: 
$\rightarrow \quad$ Vyvážení délky různých forem činnosti, odpočinku a jejich střídání tak, aby nedocházelo k nadměrné únavě, přetěžování, předčasnému opotřebování organismu.

$\rightarrow$ Opakovat jednotlivé složky režimu dne pravidelně, vždy ve stejnou dobu.

$\rightarrow$ Zařazovat různé druhy činností a odpočinku v době, která odpovídá biologickým rytmům v průběhu 24 hodin.

Ukázka některých technik:

\section{$\rightarrow$ Zhodnocení života}

$V$ této technice mají studenti uprímně zhodnotit, co v jejich životě funguje a co nefunguje. Toto hodnocení pak mohou použít jako startovní čáru při stanovování cílu pro svou budoucnost.

Pracovní list „Zhodnocení života“:

Označ body od 1 do 10 (1=nejhorší, 10=nejlepší) svưj život, jak jsi s ním spokojený, jak právě probíhá, jak se cítíš v následujících bodech:

$\rightarrow$ ty sám ...

$\rightarrow$ tvé vztahy s kamarády ...

$\rightarrow$ tvé vztahy doma ...

$\rightarrow \quad$ tvé výkony ve studiu...

$\rightarrow$ zájmy, nadání, koníčky, sport ...

Napiš, co se ti v každé z následujících oblastí daří:/Napiš, co se ti $v$ každé z následujících oblastí nedaří:

$\rightarrow$ co si myslíš o sobě ...

$\rightarrow$ tvé vztahy s kamarády ...

$\rightarrow$ tvé vztahy doma ... 
$\rightarrow \quad$ tvé výkony ve škole ...

$\rightarrow$ zájmy, nadání, koníčky, sport...

$\rightarrow$ další oblast tvého života ...

S využitím odpovědí na předcházející dotazy označ oblasti, na které by ses chtěl zaměřit. Mohou to být slabé stránky, které je třeba vylepšit, i silné stránky, které chceš ještě více posílit.

$\rightarrow$ Oblasti mého života, na kterých chci v této třídě pracovat: ...

$\rightarrow$ Vyberte si jednu oblast, která je pro vás nejdůležitější, a napište svůj cíl: ...

$\rightarrow$ Označte první krok - jednu činnost, kterou můžete provést během přištích 24 hodin - na cestě $k$ dosažení svého cíle:

(Canfield \& Siccone, 1998, s. 223) 


\subsubsection{Herní aktivity/techniky zaměřené na rozvoj nových forem sociálního a skupinového chování}

Tyto techniky umožňují komplexní rozvoj osobnosti, a to nejčastěji v interakci s druhými lidmi. Nezaměřují se jenom na nácvik elementárních osobnostních, sociálních a morálních předpokladů studenta, jak tomu bylo u předchozích technik skupiny $C$, nýbrž i na nácvik zvládání různorodých životních situací vztahujících se bud' př́mo k jednotlivci, nebo k jeho angažování v sociální skupině při řešení problémových úloh.

\section{Techniky zaměřené na „,hraní rolï“}

Techniky, které jsou zaměřené na „hraní rolí,“ mají v pedagogickém procesu osobnostního a sociálního rozvoje široké uplatnění. Tyto techniky navozují situace, které umožňují alespoň zčásti vytvářet podmínky pro získání zkušeností v oblasti, kde je jedinec dosud získat nemohl. Hermochová (1982, s. 145) charakterizuje techniku hraní rolí tak, že se jedná o novou výchovnou, vyučovací nebo převýchovnou aktivitu, při níž mají lidé možnost spontánně projevit své problémy v mezilidských vztazích, a to s pomocí partnerů a pozorovatelů.

Účastník si prostřednictvím aktivit založených na metodě hraní rolí může vyzkoušet, jaké je to v roli někoho jiného (např. rodiče, kamaráda, učitele), naučit se novým způsobům chování, které by se velmi obtížně nacvičovaly v reálných životních situacích.

Ukázka některých technik:

\section{$\rightarrow$ Rodičovský večírek}

Hráči zaujmou roli jednoho ze svých rodičů (učitelů apod.) a společně uspořádají večírek/pracovní setkání. Všichni navazují kontakty 
s dalšími hosty a hovoří o "svých" dětech (studentech atd.). Je důležité, aby každý měl př́ležitost hovořit i naslouchat. Po několika minutách se hráči posadí do kruhu a popořádku vyprávějí o tom, co objevili. (Hickson, 2000, s. 118)

\section{$\rightarrow$ Výměna rolí}

Každý si najde partnera (někoho, kdo je mu sympatický). Hráči se ve dvojicích rozdělí na hráče $A$ a hráče $B$ a najdou si místo co nejdále od ostatních. Hráč A vypráví príběh o svém náročném vztahu s jiným člověkem. Vypráví hráči B o typickém místě, kde se s tímto člověkem vídá a co se přitom říká a dělá. Po několika minutách dvojice improvizuje typické setkání, přičemž hráč A hraje sám sebe a hráč $B$ hraje člověka, o němž hráč $A$ hovořil. Po chvíli si hráči vymění role. Hráč $B$ převezme roli hráče $A$ a hráč $A$ hraje postavu, s nímž má potíže. Po uplynutí několika dalších minut se hráči vrátí do svých původních rolí a začnou improvizovat znovu. Změnil se někdo? (Hickson, 2000, s. 118) 


\subsubsection{Herní aktivity/techniky zaměřené na skupinové výtvory a výkony}

Blok technik je zaměřen na skupinovou práci, např. při vytváření společných artefaktů. $V$ průběhu technik se mimo jiné projeví, kdo se prosazuje, kdo je dominantní a kdo se podřizuje. $V$ některých herních situacích se ukáže, že dominantnost jednoho člověka je lépe snášena než dominantnost jiného, tedy že i dominance je kvalitativně různá.

Ukázka některých technik:

$\rightarrow$ Dům, strom, pes

Hra je zaměřena na skupinovou dynamiku. Skupina se rozdělí na dvojice až čtveřice. Každá skupinka má jednou tužkou, kterou drží všichni společně, nakreslit dům, strom a psa. Od samotného počátku, tj. ještě pred zadáním instrukcí, spolu nemohou členové skupiny verbálně komunikovat. Pro vzájemnou domluvu mají k dispozici pouze prvky neverbální komunikace.

\section{Techniky zaměřené na způsoby řešení skupinových úkolů}

$\checkmark$ těchto technikách předložíme skupině problém, který by měl být vyřešen. Je to výzva. Když ji skupina přijme, pak musí problém vyřešit využitím tělesných a duševních schopností všech svých členů, musí probudit svou iniciativu. Problémy či úkoly jsou koncipovány tak, aby je nemohl splnit sám jedinec nebo podskupina skupiny. Zároveň techniky mají jednotlivci ukázat, že může a měl by být efektivním členem skupiny. Skupina by měla při řešení problému využít předností všech svých členů. Otevřené je rovněž konečné řešení úkolu. $K$ cíli vede vždy několik cest a je na prríslušnících týmu, kterou z nich si vyberou. 
V průběhu technik pozorujeme první pokusy a návrhy, jak problém řešit. Dochází k výměně názorů a k jejich obhajování. Všichni zúčastnění si uvědomují, že je třeba dohodnout se na určitém postupu. Projevují se vůdcovské sklony některých účastníků i originalita nápadů jiných, kteří byli až doposud zticha. Postupně dochází k pokusům řešit problém. Často se to napoprvé nedaří. Dochází k přehodnocení plánu. Objevují se noví vůdci, nové nápady. Dochází k procesu učení pomocí pokusů a omylů, k procesu zkušenostního a prožitkově orientovaného učení. Účastníci tohoto procesu prožívají své nezdary, ale i úspěchy na vlastní kůži.

Ukázka některých technik:

\section{$\rightarrow$ Dopravní zácpa}

Hráči se rozdělí do dvou stejně početných skupin. Skupiny se postaví proti sobě, každý hráč stojí v jednom na zemi namalovaném boxu, uprostřed mezi skupinami zůstane jeden box volný. Skupiny si musí vyměnit místa. K prvnímu kroku využijí volný box ležící mezi nimi. Výměna míst probíhá podle zvláštních pravidel:

$\rightarrow$ Hráč se může posunout vpřed na volný box ležící před ním.

$\rightarrow$ Hráč jedné skupiny může postoupit vpřed také tím, že obejde hráče z druhé skupiny,

$\rightarrow$ je-li za ním volný box, nesmí však takto obcházet hráče ze své skupiny.

$\rightarrow$ Není dovolen pohyb vzad.

$\rightarrow$ Hráči se musí míjet obličejem k sobě.

$\rightarrow$ Je dovolen vždy pouze pohyb jednoho hráče. 
$\rightarrow$ Situace je vyřešena $v$ tom okamžiku, kdy se obě skupiny navzájem přemístily.

(Neuman, 1998, s. 166)

Techniky zaměřené na skupinové prožitky a způsoby řešení náročných situací

Tyto techniky zvyšují soudržnost skupiny a zároveň umožňují rozvoj osobnostní a sociální kompetence účastníků, a to především v oblasti zvyšování odolnosti vůči psychické zátěži (frustrace, stres, konflikt, nečekané životní situace apod.). Zde se výrazně projeví vliv skupiny na jedince. Lidé často v náročných situacích podléhají tlaku skupiny, a to jak v pozitivním, tak i v negativním slova smyslu. Skupina dokáže při překonávání obtížných úkolů poskytnout svým účastníkům sociální oporu, zároveň je povzbudit a zmírnit jejich obavy. Techniky, které patří do této skupiny, se často realizují ve specifických výukových prostorách (specializovaná učebna, tělocvična, hřiště apod.) a vyžadují zvýšenou pozornost pedagogů-lektorů zaměřenou na bezpečnost účastníků.

Ukázka některých technik:

\section{$\rightarrow$ Výbušnina}

Povolíme uzdu fantazii a představme si, že chytnou-li se za ruce tří členové skupiny, vytvoří výbušnou sloučeninu. Tato „sloučenina“ musí být zneškodněna transportem přes vymezené území. Během transportu se nesmí žádný z trojice dotknout země, nesmí se přerušit ani změnit způsob držení rukou. Nyní je na skupině, jak tento úkol vyřeší a přenese tuto „výbušnou“ trojici přes určené území. Na druhé straně musí být trojice postavena do výchozí polohy. (Neuman, 1998, s. 166) 


\subsubsection{Herní aktivity/techniky zaměřené na relaxaci a psychofyzické uvolnění}

Techniky k uvolnění pocitů únavy a psychického napětí

Tato podskupina technik má podobu různorodých cvičení, které umožňují odstranění psychického napětí a pocitů únavy na principu uvolňování svalů nebo regulaci dýchání.

Ukázka některých technik (postupů):

$\rightarrow$ Maximálně rozšíríme nosní dírky a nadechneme se, potom je uvolníme a pomalu plynule vydechneme, přičemž uvolňujeme svaly tváře.

$\rightarrow$ Pevně ze všech sil zavřeme oči, potom je uvolníme a necháme zavřené (uvolníme přitom i mimické svaly), zaměřujeme se na pocit uvolněnosti a plynulosti dýchání.

$\rightarrow$ Lehce stiskneme zuby, čelisti a sevřeme rty (zaměříme na to pozornost), potom uvolníme čelisti, rty a zuby (uvědomíme si kontrast mezi pocity sevření a uvolnění čelistí).

$\rightarrow$ Špičku jazyka přitlačíme k patru (směrem nahoru a dozadu), napneme jazyk a potom ho uvolníme - volně necháme ležet $v$ ústech.

$\rightarrow$ Nacvičíme si mimický výraz usmívajícího se Buddhy, který potom uplatníme $v$ situacích emočního napětí a stresu - s výrazem blahosklonnosti, koutky úst nahoru, víčka přivřená: když člověk kontroluje výraz, ovládá psychické napětí. (Lokšová \& Lokša, 1999, s. 94)

Do této podskupiny bychom mohli dále zařadit prostředky pro zvládání stresových situací a regulaci psychického napětí (trémy, nervozity). 


\section{Komplexní relaxační techniky}

V odborné literatuře (např. Blumenfeld, 1994; Lokšová \& Lokša, 1999) je popsán bohatý repertoár technik komplexního psychofyzického uvolnění. Mezi nejvýznamnější a nejužívanější patří Jacobsonova progresivní relaxace a Schultzův autogenní trénink. $\checkmark$ programech psychologie zdraví se můžeme setkat ještě s dalšími technikami, např. Machačovou relaxačně-aktivační metodou, Mariščukovým relaxačním tréninkem apod. Je nutno dodat, že v pedagogickém procesu osobnostního a sociálního rozvoje určeného pro studenty se využívá spíše modifikované varianty autogenního tréninku. Nezbytnou nutností je odborná způsobilost pedagoga-lektora, který techniku realizuje.

Ukázka některých technik:

\section{$\rightarrow$ Jacobsonova technika progresivní relaxace}

Technika je založena na nácvik uvolnění svalstva všech částí těla. Cílem je nacvičit vědomé ovládání svalového napětí při tělesném odpočinku, a tím dosáhnut odpočinku centrálního nervové soustavy. Probíhá v šesti lekcích:

$\rightarrow$ Rozlišování pocitů napětí a uvolnění svalů na hlavě - zaměřování pozornosti na svaly jazyka.

$\rightarrow$ Cvičení napětí a uvolnění svalstva ramen.

$\rightarrow$ Cvičení napětí a uvolnění sedacích svalů.

$\rightarrow$ Cvičení napětí a uvolnění svalstva hrudníku a břicha.

$\rightarrow$ Relaxace prstů rukou a nohou. 
Při nácviku uvědomění si pocitů napětí a uvolnění svalstva leží člověk klidně na lehátku v poloze na zádech. Metoda nácviku je časově náročná, základní výcvik může trvat několik měsíců až rok v závislosti na osobnostních faktorech. Probíhá pod vedením zkušeného cvičitele. Zvládnutí progresivní relaxace umožňuje autoregulovat vztah mezi svalovým a psychickým napětím. Konečným cílem je vytvořit schopnost rychlého duševního uvolnění, které vychází z poznání napětí a uvolnění svalů. (Lokšová \&. Lokša, 1999, s. 94)

\section{Techniky vizualizace - imaginace}

Jedná se o soubor dalších technik, které podporují celkové uvolnění, snížení psychického a fyzického napětí a které pracují s koncentrací. Hlavním prostředkem při dosahování požadovaného psychického stavu je vizualizace - imaginace.

Hovoříme-li o imaginaci, mluvíme o tom, jak vypadá naše představivost, o schopnosti domýšlet, o fantazii, o denním snění. Mít imaginativní schopnost znamená umět si představit něco, co už nebo ještě není a co se možná ani nikdy nestane. Tyto představy mohou mít podobu barev a tvarů, ale také čichových, dotekových nebo akustických vzpomínek. Jindy se projeví spíše jako myšlenky.

Ukázka některých technik:

\section{$\rightarrow$ Strom života/meditace}

\section{Postup:}

$\rightarrow$ Stoupněte si nebo sedněte do kruhu. Držte tělo ve vzpřímené pozici.

$\rightarrow$ Snažte se ze sebe „vytřást“ napětí. 
$\rightarrow$ Uchopte se za ruce (pokud stojíte, pokrčte trochu kolena a rozkročte se přibližně na

$\rightarrow$ šiři ramen, přičemž chodidla směřují dopředu).

$\rightarrow$ Představujte si, že vaše páteř ztělesňuje kmen stromu a vaše chodidla kořeny, které jsou pevně spojeny se zemí, a že vám $z$ hlavy vyrůstají větve jako z koruny stromu.

$\rightarrow$ Představujte si, že chodidly čerpáte ze země energii, jež postupně prochází vašima nohama, pánví, zády a dále přes ramena rukama až do konečků prstů.

$\rightarrow \quad$ Celé cvičení opakujte ještě jednou, ale nyní nechte energii proudit do hlavy, ze které se „větvemi“ bude vracet zpět do země.

$\rightarrow$ Celé cvičení zopakujte ještě jednou.

$\rightarrow$ Soustřed'te se na zvuky kolem sebe a pomalu otevírejte oči.

$\rightarrow$ Prožité pocity zkuste vyjádřit malbou.

(Cambellová, 1998, s. 51) 


\subsubsection{Techniky zaměřené na reflektování a přenos nově získa- ných zkušeností do běžného života}

Techniky zaměřené na reflexi prožitků a nově získaných zkušeností

Techniky tohoto typu se uplatňují na konci tematického bloku anebo celého programu pedagogického procesu osobnostního a sociálního rozvoje. Umožňují zrekapitulování, připomenutí, uvědomění si důležitých momentů směřujících k naplnění stanovených cílů a smyslu realizovaného programu. Tyto techniky vyžadují sebeotevření všech zúčastněných, tzn. žáků, pedagogů-lektorů a dalších organizátorů. $Z$ tohoto důvodu by se měly realizovat $v$ př́ijemné a uvolněné atmosféře, tvořivě-pestrým způsobem a s dostatkem vyhrazeného času.

Ukázka některých technik:

\section{$\rightarrow$ Výměnný trh}

Každý si zvolí partnera a diskutuje s ním o tom, co mu během uplynulého bloku aktivit či celého programu přišlo důležité nebo co ho nejvíce oslovilo. Po určitém, předem stanoveném čase si dvojice vymění role a povídá druhý. (Reitmayerová \& Broumová, 2007, s. 118)

\section{$\rightarrow$ Akvárium}

Pedagog-lektor vytvoří dva kruhy ze židlí. Do vnitřního kruhu se posadí polovina skupiny a hovoří. Druhá polovina sedí ve vnějším kruhu, mlčí, poslouchá a pozoruje. Účastníci ve vnitřním kruhu reflektují prožitý program. Po několika minutách se polovina vymění. Nová vnitřní skupina nejprve komentuje reflexi předchozí skupiny a poté sama pokračuje v reflektování programu. (Reitmayerová \& Broumová, 2007, s. 118) 
Techniky zaměřené na přenos (transfer) nově získaných zkušeností do běžného života

Jedná se o techniky, jejichž úkolem je pomoci účastníkům využít $v$ co v největší miře jejich nově získané zkušenosti v běžném životě. Tento záměr má charakter transferu (přenosu), což znamená uplatnění naučeného vzorce reagování v nové, podobné situaci. Tyto techniky se uskutečňují většinou na principu diskusí, ale zároveň se v nich užívá mentálně vizuálních schopností účastníků, jež jim mohou přibližit konkrétní reálné situace vhodné pro využití nově osvojených vědomostí a dovedností.

Ukázka některých technik:

\section{$\rightarrow$ Labyrint mého života}

Účastníci prochází labyrintem svého života. V labyrintu jsou stanoviště symbolizující hlavní druhy činností: studium, trávení volného času, kontakt s ostatními atd. Účastníci na jednotlivých stanovištích vytvoří stejně početné skupiny a ve vymezeném čase hovoří o tom, jakým způsobem mohou nově získané zkušenosti využít v symbolizované činnosti. Každý projde všemi stanovišti, pak následuje závěrečná diskuse v celé skupině. (Hrkal \& Hanuš, 1998, s. 92)

Uvedené tř́dění technik a následná její charakteristika je orientační. V lekcích osobnostně sociálního rozvoje se jednotlivé aktivity kombinují podle edukačních cílů a aktuálních potřeb studentů. 


\section{2.}

\section{DRAMATICKÉ HRY V KURZECH OSOBNOSTNĚ SOCIÁLNÍHO ROZVOJE NA FPE ZČU V PLZNI}

\subsection{Vymezení dramatické výchovy}

Obor dramatická výchova (DV) disponuje velkou baterií metod (metodou zde jednoduše rozumějme prostředek navozování učení účastníků procesu, prostředek k dosažení stanoveného cíle). Bývají tříděny různě (např. Way, 2014; Disman, 1976; Machková, 2002; Valenta, 2008).

Hlavní metodou DV je z principu divadelnosti vycházející hra v roli. Tato hra v roli může běžet jako plná hra nebo hra s jistým omezením (pohybu, slova...). ${ }^{1}$ Role navíc může být naplňována na úrovni

1 Valenta (2008, s. 123-124) metody člení do tří kategorií A, B (kategorie základních metod) a C (kategorie podpưrných metod), přičemž kategorie B, C se dále dělí. Kategorie A je kategorií, která je pro DV hlavní, určující, zcela nezbytná a navíc schopná plnit všechny cíle oboru - a patří do ní metoda plné hry (v roli). Do kategorie B pak Valenta řadí metody, které $k$ DV rovněž neoddělitelně patří, jsou to „,základní metody druhého řádu“, jsou fragmentární (částečné). Dalo by se říci, že v DV nemohou chybět, ale 
simulace, alterace či charakterizace. Vědomá práce s úrovněmi hry $\mathbf{v}$ roli a reflektování těchto úrovní jsou velmi prospěšné pro samotnou práci s dramatem (bezpečí toho, že vím, kde se pohybuji, mi umožňuje se skrze odstup do dramatu více ponořit - vrhnout se do něj - a naplno si tak prožít situace a dramata „cizích“ príiběhů), ale učí navíc účastníky sebereflektivnímu pohledu na sebe sama a na vlastní jednání v různých sociálních a životních rolích. Pochopením toho, jak změna situace (,mizanscény“) působí na naše tendence role naplňovat, dostáváme větší šanci zastávat vědomě postoje, které považujeme za správné, a nepodlehnout tak snadno situačnímu kontextu, jenž už přivedl mnoho lidí k jednání, jaké by mimo tento situační kontext šmahem odsoudili coby nepřijatelné. Účastníci hrající role poznávají sebe sama díky tomu, že mohou na omezený čas „vystoupit“ ze své vlastní kůže, a tím se nečekaně dostávají do intenzivního kontaktu se svým nitrem. (Nástrojem herce je jeho tělo i jeho psyché. Hraním rolí člověk opouští navyklé způsoby jednání a zažívá sebe sama jinak - oč nezvykleji, o to ostřeji.)

Situace, které jsou pro hru v roli typické a motivující (jsou dobrým spouštěčem), jsou situace s dramatickým nábojem. Jak uvádí Machková: „Základem dramatu a dramatičnosti je dramatická situace, tj. taková situace, $v$ níž dochází k vzájemnému působení osob na svá jednání. Je tedy přirozené, že se dramatická hra stala jedním

není nutné, aby každý lektor používal všechny. Metody kategorie B jsou rozděleny na metody a) pantomimicko-pohybové $a$ b) verbálně-zvukové. Kategorie C zahrnuje metody, které obor DV sice nekonstituují, nejsou pro něj typické, ale jsou hojně využívány pro doplnění a podpoření metod $z$ kategorií $A$, B. Jedná se o metody graficko-písemné a materiálově-věcné. (Posledně jmenované by si ovšem podle mě zasloužily patřit do kategorie $B$.) 
z podstatných prostředků té oblasti výchovy, která se dotýká zmíněné polarity individuálního a sociálního, experimentace a získávání zkušenosti v mezilidském styku a vztahu osvojování si praktických dovedností občanských, získávání praxe, zkušenosti s chováním demokratickým, tolerantním, svobodným, s poznáváním sebe sama skrze zrcadlení v druhých." (2002, s. 14)

Hra v roli však nemusí být nutně metodou plné hry, ale může být různě modifikována tím, jakou techniku v rámci této metody ještě uplatníme. V DV jsou hojně využívány různé typy rolové hry s nějakým omezením - metody pantomimicko-pohybové a metody verbálně-zvukové. Ty pak napomáhají rozvíjení účastníků opět jak směrem $\mathrm{k}$ dramatu - rozvoj divadelních dovedností a podpora tvořivosti účastníků - , tak i směrem ven do reálného života - neboli dovnitř k účastníkovým kompetencím pro život ve společnosti. Posilované dovednosti a schopnosti jako jsou komunikační sdělnost, porozumění, autenticita, sebereflexe aj., jsou těmi kompetencemi, které účastníci následně zúročují při vstupu do dalších sociálních (i asociálních) skupin a ulehčují jim socializaci i v novém prostředí.

Metody graficko-písemné jsou užívány spiše jako podpora při stavění větších hrových celků, strukturovaných či prríběhových dramat než samostatně, a vzhledem $\mathrm{k}$ tomu, že pro DV nejsou určující, nebudeme se zde o nich více rozepisovat. Jiným př́padem jsou metody materiálově věcné, které Valenta klasifikuje rovněž jako doplňující a podpůrné. Sem spadají např. takové činnosti, jako je práce s předmětem či loutkou, s maskou, kostýmem. Loutka, maska, kostým - všechny tyto prostředky umožňují skrze stylizaci zažít paradox odstupu, který nás přivede blíže. Napomáhají zichovskému přetělesnění a předuševnění. Loutka je v tomto ohledu ještě speciální tím, že loutkoherec nejedná 
za postavu skrze vlastní fýzis, ale skrze loutku, která „umí “ a „neumí“ zase jiné věci, než člověk. Vysoká míra stylizace vede k extrémnějǐím polohám v hraném projevu, uvolňuje zábrany a pomáhá rozšiřovat a zpružňovat náš rejstř́k emoční, intonační, vnitřně-temporytmický. Tím se opět rozvíjejí dovednosti pro drama a divadlo i dovednosti životní. Celkově je možno říci, že metaforičnost, která metody vycházející z principů divadelnosti a dramatičnosti velmi často provází, umožňuje: „obejít či překonat své vnitřní bloky či překážky a projevovat se autenticky“. (Mackewn In Polínek, 2015, s. 45)

Metody DV jsou také metodami učení činnostního, zkušenostního (byt' se pracuje s fantazií a fikcí) - a to jsou také důvody, proč je poznání, které skrze ně k účastníkům přichází, formativního charakteru: k poznání se nedochází skrze mentorování a pouze rozumem, ale skrze zážitek - je tedy „zažito“.

Socializační efekt oboru prohlubuje i to, že krom poznání jsou získávány i praktické sociální dovednosti. DV (stejně jako i další systémy) využívá také tzv. modelové situace, kde se často využívá hry v roli na úrovni simulace. ${ }^{2}$ Účastníci si v nich vyzkoušejí nové způsoby jednání, a dovednosti, jež jsou při nich potřeba, si jejich zažitím také osvojují.

2 Interaktivní hry neboli modelové situace jsou hojně využívány hlavně v zahraničí, ale začínají se častěji objevovat i u nás. Neznamená to, že se vždy jedná o hraní rolí nebo že je mezi nimi a DV rovnítko. Rolové modelové situace jsou jedním z typů modelových situací, typem, který je v DV poměrně zaběhnutý. S interakčním učením se můžeme setkat $v$ sociálně-psychologických výcvicích, v OSV, ve výcvicích asertivity, komunikace. U Valenty se můžeme setkat i se zastřešujícím termínem interakční pedagogika. (Valenta, 1999, s. 10) 
Zásadní roli v DV hraje reflexe. Tuto většinou (ale ne vždy) „mimorolovou" metodu zmiňujeme explicitně proto, že bez ní by se edukační efekt použitých metod nezhodnotil. $\mathrm{Na}$ její důležitost upozorňuje i Heathcotová. Reflexe slouží ke zkoumání a zvědomování pocitů, pochopení „co je za...“. Při jejím užití v průběhu príběhových dramat napomáhá $\mathrm{k}$ odstoupení od prríběhu i role, které paradoxně prohloubí naše další emoční zapojení v dramatické akci. (Wagner, 1976) „Reflexí se učíme distanci od emocí okamžiku, aniž opustíme plnost těchto pocitů, reflexe učiní vědění něčím, čeho se můžeme dotknout a příště toho třeba využít. Tento proces je vlastně edukací pocitů - pocity bez reflexe mohou být nastoleny a pak zapomenuty, s reflexí se stávají vhledem, porozuměním, jež modifikují příšti chování v reálném světě." (Kasíková, 1995, s. 26) Důležitost reflexe vnímají i ostatní zážitkové systémy - např. Pelánek (2008) zdůrazňuje, že právě ona dělá z rekreačního zážitku zážitek pedagogický. 


\subsection{Metoda strukturovaného dramatu}

Metoda dramatické výchovy nazývaná pro její často velmi promyšlenou výstavbu strukturované drama (možno potkat i názvy př́běhové či školní drama) stojí za zvláštní pozornost, nebot' stojí na rozhraní hraného dramatu, vyprávěného prríběhu a výukového programu, a je efektivní a pro účastníky velmi přitažlivou metodou osvojování určitých ( $v$ každém dramatu jiných) obsahů (at’ už vědomostních, dovednostních, schopnostních či postojových a hodnot se týkajících). Pro osobnostně sociální rozvoj účastníků edukačního procesu je důležité, že umožňuje a podporuje rozvíjení jejich klíčových kompetencí.

Strukturované drama bývá účastníky postupně odkrýváno, vytvářeno a přisvojováno pomocí různých technik. Toto rozkouskování v sobě nese mnoho výhod: do dramatu se postupně dostává mnoho dějových fakt a vznikají věrohodné charaktery. Účastníci nemusejí být herecky perfektně vybavení, aby jim dokázali vdechnout život. Tím, že se na tvorbě príběhu, charakterů a jednání podílí více lidí, dostává se do hry mnohovrstevnatost, která je v životě samozřejmá, ale kterou by účastníci nebyli schopni dostat do herecké práce, kdyby pouze dostali text a př́běh přehráli. Mezi jednotlivými technikami probíhají všudypř́tomné reflexe, ve kterých účastníci mohou od látky poodstoupit, přemýšlet o ní, konfrontovat s ostatními své názory na ni, a pak se „vybavenější“ a v „kramflekách silnější“ do příběhu znovu ponořit. Tím se posiluje i herecká vybavenost účastníků - jsou si jistější budovanými charaktery, učí se pocitu, že mohou „do cizí kůže“ vklouznout bezpečně, že skupina chápe, že postavou prezentované postoje 
nejsou jejich vlastní, a nebude je za ně odsuzovat. Navíc zde často vstupuje do role i učitel, což drama často „,zahušt'uje“. Je-li totiž kdokoli schopen v roli vážně jednat, umožní to samé i svým partnerům v situaci. Jak trefně formulovala Ulrychová (2007, s. 12): ,, Je snazší reagovat na jednání - at' už fyzické nebo slovní - druhého, než sám akci otevřít a rozvíjet.“ Jen tím, že si takové jednání „na vážno“ účastníci vyzkoušejí, učí se ho sami vytvářet. Strukturované drama má i tu výhodu, že mu ani improvizace a scény odehrané jako vtip neuberou na síle. Fakta se do hry dostávají tak jako tak a je často velmi silný zážitek, jak se během práce, která všechny baví a je stavěna na výstupech, jejichž hlavním posláním je v tu chvíli pobavit ostatní, najednou objeví dramatický moment, který všechny strhne a umožní jim prožít katarzi ,,jako na divadle“. Vlastně je příjemné, že účastníci nemusejí být po celou dobu práce seriózní, byt’ se často jedná o závažná témata. Bylo by to asi i k nevydržení. A tak se dramatický katarzní zážitek pojí i s překvapením. Tím, že účastníci, byt' často i s nezodpovědností a pro pobavení, sami situace vytvořili, zabydleli se v daném příběhu, vybudovali si důvěru v příčiny a následky jednání jimi vytvořených charakterů, přijímají to, co se postavám děje, za vlastní. A tím se otevírá cesta k opravdovému dosažení stanovených edukačních cílů. 


\section{Ukázka strukturovaného dramatu Čarodějnické procesy³}

Téma: xenofobie.

\section{Cíle:}

$\rightarrow \quad v$ rovině osobnostně-sociální:

$\rightarrow$ hlavní cíl: účastníci se společně zamyslí nad diverzitou společnosti a důvody, proč a jak společenství na odlišnost reaguje

$\rightarrow$ cíle vedlejší: účastníci spolupracují nad jednotlivými úkoly, využívají a rozvíjejí své komunikační dovednosti, schopnost formulovat a argumentací podpořit vlastní názor, prosadit se a zároveň poskytnout prostor ostatním, mají odpovědnost za společnou práci

$\rightarrow \quad v$ rovině dramaticko-divadelní: účastníci si vyzkoušejí hru v roli na úrovni charakterizace a práci s obrazovou metaforou (vyjádření tělem)

$\rightarrow \quad v$ rovině vzdělávací: účastníci se seznámí $s$ českou podobou honů na čarodějnice, zjistí, kde k nim v Čechách docházelo a zamyslí se nad důvody proč zrovna „tam“.

Pomůcky: atributy postav/části kostýmů (zástěra, klobouk, růženec, šátek na hlavu, šátek přes ramena, př́padně navíc i nějaké šátky, sukně, vesty...), hudba, lístečky s úkoly, mapa Čech, mapky okolí Zlatých Hor, obrázky mučidel (palečnice, španělská bota, žebřík), text vyhlášky a závěrečného čtení, papíry, propisky, fixy, balicí papír, olejové křídy

Časová náročnost: 5 vyučovacích hodin

3 Toto drama je citováno v publikaci Projekty dramatické výchovy pro středoškoláky (ed. Machková, 2012). Pro kurz OSR2 s vysokoškolskými studenty bylo drobně upraveno. 


\section{Průběh dramatu:}

\section{Boj - rozehřátí, uvolnění, naladění na hereckou práci s tělem}

„V následujících hodinách se budeme pohybovat v jiném časoprostoru než doted'. Přesuneme se do malé vesničky Ondřejovice po skončení 3oleté války. Nyní si na rozehřátí vyzkoušíme pár bojových technik, které mohly být v této válce využity."

Boj na dálku:

Studenti se rozdělí na dvě poloviny, postaví se do dvou řad proti sobě na opačné straně místnosti. Pantomimicky ztvárňují různé druhy použití zbraní:

» házení kamení po neprríteli

» střelba z praku

» střelba z luku

» hod oštěpem

» střelba z kuše

Boj zblízka:

Studenti se rozdělí do dvojic a ve zpomalené pantomimě zkoušejí boj s různými zbraněmi. Ve výpadech se střídají, stejně důležité jako zahrát přesně výpad, je i zahrát reakci na něj (inkasování rány, její odražení či úhybný manévr).

» řemdih

» palcát

» sekera

» pěsti

» nože

» zemědělské nářadí 
Souboj na život a na smrt:

Studenti si ve dvojicích nacvičí přesnou choreografii souboje, ve kterém během cca 10 akcí jeden z protivníků zemře. Zbraně a styl jsou libovolné. Pohyb může být pantomima, př́padně zpomalená pantomima. Skupina postupně shlédne všechny souboje.

\section{Závěr aktivity - přemostění:}

„V tuto chvíli okolo sebe vidíme velký počet zabitých bojovníků stejně, jako tomu bylo na bitevních polích zoleté války“

\section{Uvedení do časoprostoru dramatu}

„Pojd'me se ted' společně přesunout do malé vesničky Ondřejovic v polovině 17. století.“

» rozdám mapky se zakroužkovanými Ondřejovicemi (u Zlatých Hor alias Cukmantlu)

» řekneme si, co to je za kraj, ukážeme si ho na mapě Čech.

» studenti si po skupinkách připraví krátký historický výklad pro ostatní; čerpají z materiálu od učitele

Polovina 17. stol, tedy po roce 1650 - co je to za dobu - po zoleté válce (1618-1648), zem je zplundrovaná, v Čechách vládnou Habsburkové (Ferdinand III., císař římsko-německý, král český a uherský), rekatolizace země, nevolnictví.

$\rightarrow \quad$ společné kreslení Ondřejovic, jak mohly vypadat. Diskuse nad plánem Ondřejovic.

Čím se zde asi lidé živili; dle mapy je vidět, že kraj je lesnatý, kopcovitý zemědělství, lesní dělníci, horníci, řemesla, nevolnictví přitvrzuje na dva dny v týdnu. 
Mapa/obraz tehdejších Ondřejovic - společné kreslení (kruh - sezení na židlích okolo stolu)

Studenti společně vytvářejí mapu Ondřejovic, ujasňují si, kdo kde bydlí...

$\rightarrow$ Přestávka 15 min. $\leftarrow$

\section{Na rynku - živý obraz}

„Je neděle, lidé ze vsi byli na mši. Po skončení mše vycházejí na plac před kostelem a baví se mezi sebou. Zde jsou vrata kostela a já vás poprosím, abyste po jednom přicházeli, řekli, kdo jste, čím se živíte, označili na mapě vesnice, kde bydlíte, a postavte se do živého obrazu povídajících si lidí před kostelem. O čem se asi tito lidé baví? Až tlesknu, obraz na chvilku ožije, tlesknu podruhé, opět strne.“

$\rightarrow \quad$ Učitel okomentuje, co zaslechl.

\section{Setkání s Barborou - učitel v roli}

„Je rok 1652 a v Ondřejovicích žije sedmnáctiletá dívka Barbora Kupferschmiedová. Já ted' na chvíli vstoupím do její role (rekvizita šátek) a každý z vás má nejvýše jednu otázku, kterou jí může položit. Pokuste se o ní dozvědět co nejvíce."

$\rightarrow$ Barbora Kupferschmiedová

$\rightarrow 17$ let

$\rightarrow$ sirota, rodiče zemřeli na nějakou nemoc před rokem

$\rightarrow 1$ starší bratr, utopil se, když bylo Barboře 8 (byli spolu u rybníka)

$\rightarrow$ žije sama v domku po rodičích - chudých rolnících, stará se o malé políčko, ale to nestačí, takže si přivydělává, jak to jde. 
Nejčastěji ji potřebují na statku a pak taky pomáhá porodní bábě, která se o ni nejvíce stará. Díky tomu zná některé byliny. Taky samozřejmě chodí do roboty na pole.

$\rightarrow$ je věřící, velmi si váží pana kněze

$\rightarrow$ miluje syna ze statku, kde pracuje, ale statkářka už jí dala najevo, že není žádoucí snachou.

Krátká rekapitulace, co jsme se dozvěděli.

\section{Současný Barbořin život - plná hra (jen 1 min.)}

Nové 4 skupiny, každá dostane lísteček se situací, kterou sehrají, potřebné atributy postav (Barbořin šátek se bude půjčovat)

$\rightarrow$ Barbora s knězem - v kostele, zpověd'

$\rightarrow$ Barbora s milým - někde na statku

$\rightarrow$ Barbora s někým ze vsi - v robotě

$\rightarrow$ Barbora s porodní bábou - u báby v chalupě

Scénky by nám o Barboře měly něco prozradit - jaká je, co má ráda, čeho se bojí...

Krátká rekapitulace, co jsme se dozvěděli.

Stejné skupiny, ještě jedno „lístkové“ zadání - seznámili jsme se s Barborou, něco už o ní víme. Stejně tak víme něco o lidech, kteří hrají důležitou roli v jejím životě. Podíváme se ted' na několik konkrétních situací, které měly v jejím životě nečekaně velký význam.

$\rightarrow$ Barbora a milý; on jí říká, že už je to beznadějné, matka jejich sňatek nikdy nepovolí a otec, který by se možná dal přesvědčit, zřejmě umírá. (Horkost, kašel). 
$\rightarrow$ Barbora a bába; radí se s ní, co dělat proti horkosti a kašli statkáře- otce Barbořina milého, když žádné byliny nezabírají. Bába poradí jedině dát mu pod matraci posvěcenou hostii. Tu je těžké získat.

$\rightarrow$ Barbora a kněz; Barbora prosí kněze o hostii, která by mohla uzdravit otce milého (vypadá, že brzy zemře). Kněz je zděšen, že Barborka věří takovým pověrám a že by byla schopna jimi znesvětit hostii. Rezolutně odmítá.

$\rightarrow$ Barbora a statkářka; statkářka zoufalá z možné smrti manžela, chce, aby Barbora udělala na jeho záchranu cokoli (zná přeci kouzla od báby), slibuje hory doly, nakonec i syna.

Trvání 2 minuty. Důležité je respektovat charaktery postav a prostředí. Každá skupina vymyslí a napíše dialog, kde se odehrává. Scény jsou předvedeny v přesném pořadí (milý, bába, kněz, statkářka)

\section{Cesta k prijiímání - ulička svědomí}

„Barbora byla na mši a po celou dobu byla nepozorná, rozhodovala se, co má udělat. Nakonec se rozhodla hostii ukrást. Mše skončila, všichni jou ke svatému prijímání. My ted' Barboru vyprovodíme cestou k oltárii."

$\rightarrow$ Dobrovolník bude Barborou. Ostatní vytvoří uličku, kterou půjde. Jak bude pomaličku procházet, každý řekne jednu věc, která jí asi běží hlavou.

$\rightarrow$ Když Bára dojde na konec uličky, poklekne jako k přijímání a obraz strne. 
$\rightarrow$ Barbora zůstane, jak je. Ostatní si stoupnou okolo. Klečí před knězem, chce ukrást hostii, nikdo ji nesmí vidět. Jak to udělá?

$\rightarrow$ Přestávka 15 min. $\leftarrow$

\section{Statkářčina intrika - kolektivní postava $\times$ učitel $v$ roli}

„Barbora dala hostii pod polštář statkáře a ten do půlnoci zemřel. Statkáŕka, která Barboru nikdy ráda neměla, ji ted' nenávidí, chce se jí zbavit. Vypraví se ke knězi. Vy všichni se ted' na chvíli stanete knězem, ke kterému za chvíli přijde statkářka."

$\rightarrow$ Statkářka: Barbora je čarodějnice, zabila jí muže, ukradla a znesvětila hostii, určitě může i za smrt bratra a rodičů, je divná, často jí vídá v noci venku a za bouřky chodí vždycky na hřbitov.

$\rightarrow$ Přesvědčuje kněze, aby to nahlásil děkanovi z Cukmantlu, má strach, nedávno přece řádily čarodějnice $v$ Petrovicích a nebýt zásahu tribunálu, Bůh ví, jak by to tam dopadlo...

\section{Vyhláška - živý obraz}

„Takhle tedy proběhla návštěva statkářky u kněze. Kněz (at’ se mu to zdálo vhodné nebo ne) raději o tom napsal děkanovi. Dva týdny poté visela na vratech kostela vyhláška."

Postavte se do obrazu debatujících vesničanů před kostelem, jak jste stáli na začátku.

Učitel přečte vyhlášku:

„Jelikož my, inkviziční soudce pověřený prošetřením zločinů čarodějnictví ve vratislavském knížectví, vší svou mocí usilujeme a celým 
svým srdcem se snažíme chránit nám svěřený křest’anský lid v jeho jednotě a štěstí katolické víry a vzdálit ho každé ráně ohavného kacířství, proto my, výše řečený soudce, jehož úřadu to přináleží, k slávě a poctě ctihodného jména Ježíše Krista a pro pozdvižení svaté pravé víry a pro potlačení ohavnosti kacířství, zvláště všech čarodějnic obecně i každé zvlášt' jakéhokoliv jsou stavu a postavení, pod trestem exkomunikace nařizujeme, že ve lhưtě dvanácti dnů nahlásí každý, zda ví, viděl nebo slyšel, že nějaká osoba je považována za kacíře nebo čarodějnici, či je podezřelá z takových činů, jako je způsobování škod lidem, dobytku a plodů země.“4

Na tlesknutí se obraz rozžije, na druhé strne. Ves se baví o vyhlášce.

\section{Rekapitulace}

Co si lidé myslí, proč se objevila vyhláška, podezřívají někoho? Mají strach o sebe?

\section{Utvoření tribunálu - diskuse v kruhu}

Co se vlastně stalo - do Ondřejovic dorazil inkvizitor z Cukmantlu, který dva poslední roky pracoval v blízkých Petrovicích. Inkvizitor ale k procesu nestačí. Jak je v Kladivu na čarodějnice psáno:5

„Jestliže někteří předstoupí před soudce, aby podali informaci, měl by soudce věnovat pozornost tomu, aby postupoval následujícím způsobem. Necht' je př́tomen notář a dva řádní lidé, bud' duchovní nebo laici, anebo jestliže nelze opatřit notáře, necht' jsou na místě notáře dva vhodní lidé. Dále: v př́tomnosti těchto osob budou výpovědi

4 Upraveno podle Kladivo na čarodějnice, s. 471

5 tamtéž 
svědků důvěryhodně sepsány veřejným úředníkem, jestliže je možné ho zajistit, nebo, pokud ne, dvěma vhodnými muži.“

$\rightarrow$ Kdo je soudce, koho dalšího máme, koho nemáme, kde ho vezmeme.

$\rightarrow$ Kdo je vhodný kandidát, jak myslíte, že by na to reagoval, myslíte, že by se někdo přihlásil dobrovolně? Proč ano / ne?

$\rightarrow$ Našel se v Ondřejovicích vhodný člověk na práci kata a žalářníka (ten měl na starost i torturu)? Nebo museli poslat do Cukmantlu?

Diskuse, ve které se vyberou vhodní lidé ze vsi do tribunálu.

\section{Tribunál - práce ve skupinách, plná hra}

$\rightarrow 4$ skupiny, vylosují si roli (tribunál, selka, Barbořin milý, porodní bába).

$\rightarrow$ Tribunál si připraví postoj ke svědkům, k př́padu (je třeba s nimi mluvit, aby si ujasnili, oč tribunálu jde a nebyli zbytečně humánní).

$\rightarrow$ Ostatní skupiny připraví, s čím jejich zástupce v roli postavy přijde za tribunálem.

Plná hra, tribunál zůstává kompletní, ostatní skupiny vyšlou zástupce, někdo z tribunálu zapisuje obvinění.

Návštěva kněze u Barbory - kolektivní postava versus učitel v roli „Na základě těchto obvinění byla Barbora zatčena a zavřena do provizorního vězení (kde ho asi mohli zřídit - plán vsi. A kde asi bydlel inkvizitor?) Každý z vás je ted' Barbora, sedící ve vazbě, čekající, co 
bude dál. Je u ní na návštěvě kněz - já. Posad'te se do živého obrazu, každý jak myslíte, že Barbora sedí. Až kněz promluví, obraz ožije.“

$\rightarrow \quad$ Kněz seznamuje Báru s obviněními.

$\rightarrow$ Ptá se na pravdu.

$\rightarrow$ Ptá se, zda se účastnila sabatů na Ďáblově kopci u Petrovic, kde se setkávaly s d'áblem i petrovické ženy usvědčené a odsouzené jako čarodějnice.

$\rightarrow$ Snaží se ji přesvědčit, aby se přiznala.

$\rightarrow$ Varuje před torturou.

\section{Barborčin poslední dopis - samostatné psaní}

„Barbora sice neuměla psát a nemohla ani nikomu napsat dopis z vězení, ale já bych vás chtěla poprosit, abyste si každý vzal papír a napsal dopis, jaký myslíte, že by napsala v tuto chvíli Barbora, kdyby mohla. Adresát je na vás. Až dopíšete, prrijd'te se posadit do kruhu."

$\rightarrow$ Hlasité předčítání dopisů - každý čte, když má chut’.

\section{Představení mučidel}

$\rightarrow 4$ skupiny, každá si vezme jeden obrázek, rozmyslí si, co to je, zná-li název, vymyslí, jak se asi nástroj užíval.

$\rightarrow$ Zástupce ukáže ostatním obrázek a představí ho. „Dokážete si představit, že byste vydrželi „se nepřiznat"?“" 


\section{Závěrečné stání}

„Víme už, kdo je v tribunálu, pojd'me si ted' postavit, jak kdo stál při závěrečném stání. Tribunál, lidé ze vsi, Barbora... postavte se na jejich místa, jen Barbořino místo nechte volné." (Tam jen položím její šátek.)

$\rightarrow \quad$ Vydržte v živém obrazu, zavřete si oči.

$\rightarrow$ Co myslíte, že si mysleli o Barboře přítomní lidé? Co si myslel člověk, na jehož místě stojíte? Co si myslel o její vině/nevině? Co si o tom myslíte vy?

$\rightarrow \quad J a ́$ vám ted' přečtu zápis, který popisuje konec Barbořina života:

„Vydali ji na mučení. Španělské boty, řádným i mimořádným způsobem. Svázali jí obě nohy do dřevěných desek a mezi ně pak vráželi klíny, čím dál širší. Bylo slyšet, jak jí praskají kosti. Křičela. Ve dvě hodiny měla nohy tak rozmačkané, že jí z nich vytékal morek. Pak se ke všemu přiznala a označila spoluviníky. Ve čtyři hodiny byl přede všemi vynesen rozsudek tohoto znění:

My, soudce a př́sedící, poté, co jsme vzali v úvahu a pečlivě dbali na podrobnosti řízení vedeného proti tobě, Barboro Kupferschmiedová, a co jsme pečlivě prošetřili celou věc, zjistili jsme, že se jasně jeví, že jsi řádně usvědčena z kacířství čarodějnictví a tedy prohlašujeme, soudíme a odsuzujeme tě dnešního dne ve čtyři hodiny odpoledne k trestu smrti upálením a to zítra ráno o desáté hodině.

Večer se vyzpovídala knězi a ráno v devět jí natáhli košili napuštěnou sírou, na krk jí vložili oprátku, naložili ji na káru a odvezli k hranici. Zvon v kostele zvonil. Někteří se za ni modlili. Hranice byla taková, 
jaké se obvykle používají: suché dřiví a sláma navršené kolem kůlu. Na kůlu viselo jakési sedlo či železná židlička, kam ji přivázali. Sama už na nohou stát nemohla. Kat ji zardousil pomocí oprátky a zapálil hranici. Pak vše zahalil kouř.

Téhož dne večer bylo zatčeno osm lidí denuncovaných Barborou Kupferschmiedovou jako čarodějnice."

$\rightarrow$ Otevřete oči a až budete chtít, posad'te se okolo tohoto papíru a kreslete, na co máte chut.“

Reflexe kreslením

$\rightarrow$ Hudba, velký balicí papír, barevné kř́ídy.

$\rightarrow$ Každý kreslí, co chce.

$\rightarrow$ Když skončí hudba, všichni dokončují své kresby.

$\rightarrow$ Každý ke své kresbě řekne, co chce říci, ostatní se mohou na ni zeptat.

$\rightarrow$ Přestávka 15 min. $\leftarrow$

\section{Závěrečná reflexe v kruhu}

$\rightarrow$ Setkali jsme se s jedním konkrétním osudem dívky odsouzené pro čarodějnictví - co vedlo lidi z Ondřejovic k tomu, aby uvěřili, že Barbora Kupferschmiedová, kterou 17 let znali, je čarodějnice?

6 Kompilace ze Snů o růžích a ohni a Kladiva na čarodějnice. 
$\rightarrow$ Co obecně mohlo lidi vést $k$ přesvědčení, že je někdo čarodějnice?

$\rightarrow \quad$ V jakých dějinných událostech vidíte xenofobní projevy?

$\rightarrow \quad$ Kdo je odmítán/nepřijímán/nenáviděn dnes?

$\rightarrow$ Kdo nám připadá odlišný, divný, koho nechápeme, koho se bojíme...

$\rightarrow$ Můžeme si (s ohledem na ty, kterých se bojíme či je třeba nemáme rádi) $z$ dějin vzít nějaké poučení - pro nás osobně? 


\section{3.}

\section{POSTŘEHY ZE STUDENTSKÝCH REFLEXÍ}

\subsection{Popis realizace reflexe}

Studenti po skončení kurzu KPG/OSR2 (Osobnostní a sociální rozvoj 2) vypracovali písemnou reflexi, ve které odpovídali na následující otázky:

$\rightarrow$ Přínos předmětu pro mě (pro můj osobnostní a sociální rozvoj).

$\rightarrow$ Př́nos předmětu pro skupinu (pro rozvoj skupinových vztahů).

$\rightarrow$ Př́nos předmětu pro praxi (pro rozvoj profesních kompetencí).

$\rightarrow$ Komentář k lektorům a k průběhu kurzu.

Po odevzdání písemné reflexe se uskutečnila diskuze, ve které účastníci zrekapitulovali svoji účast a volně se vyjadřovali k př́inosu kurzu. 


\subsection{Zobecňující výsledky z reflexí}

Studenti si předmět KPG/OSRz zapsali na základě zkušeností z absolvování povinného kurzu KPG/OSR. Ten je zařazen do 1. ročníku studia na FPE a jeho základním cílem je nabídnou studentům v praktických ukázkách metody a techniky vedoucí k uvědomění a rozvíjení osobních pedagogických kompetencí. Studenti do navazujícího kurzu KPG/OSR2 vstupovali s očekáváním, že si prohloubí znalosti a dovednosti, jejichž rozvoj byl započat v dř́vějším kurzu.

Mezi nejčastější očekávání studentů na začátku kurzů patřilo:

» zvládání ostychu před ostatními

» prohloubení poznání vlastních osobnostních vlastností v interakci s druhými

» dosažení schopnosti vyjádřit názor před skupinou a nebát se/nemít trému při vystupování v početnější skupině

» získání dovednosti spolupracovat s ostatními

» hlubší poznání spolužáků

Z výpovědí studentů vyplynulo, že se do prohlubujících kurzů osobnostního a sociálního rozvoje hlásí dvě odlišně nastavené skupiny studentů. První skupinou jsou studenti z hlediska osobnostních vlastností otevření interakci s druhými a druhou skupinou naopak studenti spíše introvertní a interaktivním technikám se obvykle vyhýbající.

Studenti extravertního osobnostního ladění si kurzy přišli tzv. užít. Přihlásili se proto, že záměrně vyhledávají aktivity, v nichž je 
možné spolupracovat a komunikovat s ostatními. Studenti introverti naopak vstupovali do kurzů s motivem překonat sama sebe, naučit se větší otevřenosti vưči ostatním a pokusit se přemoci své uzavřenější projevy při jednání s nimi. Tato heterogenita ve složení skupiny se v průběhu práce ukázala jako prospěšná, nebot' tak došlo k uspořádání korelujícímu s běžnou sociální skupinou.

Účastníci v závěru kurzů vyzdvihovali jako přínosné pro ně osobně:

$\rightarrow$ Zážitek komunikace s druhými v různých rovinách:

» Vzájemné sdělování informací o sobě - sebeotevření, důvěra; naslouchání druhým (zapamatování podstatných informací o nich), trpělivost při naslouchání, snaha o oboustranné pochopení;

» Řešení problémových úloh ve skupině - umění sdělit nápad a argumentačně ho zdůvodnit, nacházet konsenzus;

» Diskuze s ostatními na rưzná témata - formulování a vyjádření osobních postojů a hodnot, reflexe postojových a hodnotových názorů svých vlastních i cizích (ostatních členů skupiny).

\section{$\rightarrow$ Zážitek z prezentace vlastní osoby v inscenačních aktivitách.}

» Nácvik, zkoušení, experimentování v oblasti verbálních a neverbálních výrazových prostředků při ztvárňování různých fiktivních rolí. Při tomto způsobu prezentování sebe sama si někteří uvědomili, a také tím sami sebe překvapili, že prostřednictvím fiktivní role se dokáží nečekaně spontánně a bezprostředně vyjadřovat, projevovat své emoce a názory. Že se tak dokáží zbavit ostychu a projevit před ostatními své spontánní chování. 


\section{$\rightarrow$ Zážitek z kooperace.}

»Zvědomění vlastní role či způsobu chování ve skupině při řešení problémových úloh. Zde se projevilo osobnostní zaměření - introverze $\times$ extraverze, dominance × submisivita, konformita $\times$ nonkonformita a dovednostní dispozice pro řešení úloh podle zaměření.

\section{$\rightarrow$ Zážitek ze skupinové podpory.}

» Účastníci kurzu uváděli, že skupina byla pro ně velkou sociální oporou při nácviku osobnostních a sociálních dovedností. Před ostatními se nebáli projevit své názory, postupně ztratili ostych a dokázali ostatním důvěřovat.

Jako př́nosné pro skupinu uváděli studenti:

\section{$\rightarrow$ Hlubší vzájemné poznání.}

Objevila se problematika sociální percepce, proces formování dojmů o druhých lidech na základě jejich verbálních a neverbálních projevů. Účastníci v reflexi přiznali, že první dojem o druhých byl zavádějicí a v průběhu aktivit se výrazně měnil. První dojem byl spiše záporný, studenti si navzájem percipovali spíše negativní vlastnosti (např. uzavřenost, frajerství, namyšlenost atd.). Na konci kurzu naopak uváděli, ,jak se perfektně sešli“ a vzájemně se hodnotili velmi pozitivně. (Celkově by se dalo říci, že se potvrdilo očekávání, že lidé, kteří něco společného prožijí, kladné či náročné situace, mají k sobě blíž, vyzdvihují u druhých pozitivní vlastnosti a př́padné negativní projevy snáze akceptují. Uvedenou zkušenost z realizovaného kurzu Ize promítnout do koncepce adaptace 
studentů na vysokoškolské prostředí a na začátku akademického roku zorganizovat stmelovací kurzy s cílem vytvořit studijní skupiny založené na pozitivních vztazích mezi členy.)

$\rightarrow$ Vzájemná tolerance, schopnost a ochota všech členů spolupracovat, vzájemné naslouchání.

Někteří v reflexi popsali své překvapení nad tím, jak se introvertní a uzavření členové skupiny dokázali hned druhý den kurzu otevřít a spontánně projevovat před celou skupinou. Nabízí se otázka, zda tito účastníci byli svým osobnostním zaměřením introverti nebo zda byli za introverty pouze považováni na základě uzavřenosti pramenící odjinud.

- Poznání nových lidí, navázání nových přátelství.

Přínosným pro praxi studenti shledávali:

$\rightarrow$ Seznámení s herními aktivitami, jež je možné použít v současné a budoucí pedagogické praxi účastníků.

Zažité aktivity pro ně byly inspirací pro tvorbu programů v rámci volnočasových aktivit, např. zájmových kroužků, letních táborů atd. Někteří přímo uvedli, že realizované hry mají široké použití ve všech oblastech mezilidských vztahů, dají se využít ke zlepšení komunikace $v$ rodině, mezi přáteli atd. Mnoho účastníků nahlíželo na př́nos kurzu pro praxi spíše pragmatickým způsobem, tj. jako na způsob získání námětů pro realizaci vlastních kurzů.

\section{$\rightarrow$ Průprava pro profesní rozvoj.}

Studenti ocenili, že se zlepšili v naslouchání ostatním, ve vyjadřování myšlenek a argumentů, ve zvládání ostychu před ostatními, 
v chápání principů spolupráce atd., což je podle nich to, co budoucí učitel nutně potřebuje.

Jako komentář k lektorům a průběhu kurzu se objevilo:

$\rightarrow$ Spokojenost $s$ formátem kurzu

Předmět byl vyučován blokově mimo běžné prostory fakulty. Jednalo se o koncentrovanou formu učení, kdy se $v$ jednom časovém termínu studenti intenzivně věnovali výuce, nácviku osobnostních a sociálních dovedností. Mohli se plně soustředit na jednu oblast učení a nebyli rozptylováni dalšími povinnostmi, které musí při klasické výuce $v$ průběhu dne řešit. Spatřovali výhodu také $v$ tom, že se kurz uskutečnil mimo prostory fakulty, ve výcvikovém středisku Nečtiny. Do programu mohly být zařazovány tzv. klubové večerní aktivity, které umožňovaly pokračovat v nácviku různých osobnostních a sociálních dovedností i v méně formální podobě.

$\rightarrow$ Ocenění vedení aktivit $v$ duchu humanistické pedagogiky, tzn. respektování osobnosti a potřeb každého účastníka.

Účastnici kladně hodnotili způsob vedení kurzu, kdy lektoři nevystupovali z pozice autority, ale byli facilitátory dění. Oceňovali osobní zapojení lektorů do realizovaných aktivit. To podle nich zmenšovalo odstup učitel - student. (Jeden lektor aktivitu uváděl a druhý se účastnil s ostatními, př́padně, bylo-li to možné, byli v aktivitě zapojeni oba.) 


\section{ZÁVĚR}

Závěrem můžeme zrekapitulovat nejdůležitější fakta, která se týkají problematiky osobnostního a sociálního rozvoje ve vzdělávání učitelů na FPE ZČU v PIzni.

Osobnostní a sociální rozvoj je záměrný a cílevědomý pedagogický proces, jehož cílem je př́znivý rozvoj (růst) všech složek tvořících osobnostní a sociální kompetenci účastníka procesu, $v$ tomto prípadě budoucího pedagoga.Patř́ sem rozvoj vědomostí, dovedností, postojů a hodnot potřebných pro plnohodnotný osobní život jedince a jeho optimální orientaci v mezilidských vztazích a profesních situacích. Proces je obsahově zaměřený na témata vztahující se k osobnosti člověka ( $k$ sobě), k jednání člověka v mezilidských vztazích ( $k$ druhým), k profesním situacím a pedagogickým kompetencím (k profesi) apod. Témata osobnostního a sociálního rozvoje se ale vzájemně prolínají, nelze je zcela kategoricky dělit do uvedených oblastí. Inspirativním zdrojem pro koncipování a realizování osobnostního a sociálního rozvoje jakožto předmětu jsou tzv. teoretické systémy osobnostního růstu. Mezi ně patří: osobnostní a sociální výchova, dramatická výchova, sociálně psychologický výcvik, globální výchova, etická výchova a multikulturní výchova. Osobnostní růst je v rámci předmětů OSR a OSR2 uskutečňován prostřednictvím rozmanitých herních aktivit/technik. Techniku je zde možné vymezit jako postup, který není do detailu dotvořen, ale je dopracován podle konkrétní situace, požadavků a potřeb 
účastníků kurzu. Mnohé techniky mají různé použití podle toho, jaký cíl je sledován a na co se při jejich aplikaci klade důraz. Každá technika má své možnosti, př́nosy, ale také svá rizika. Jedním z dalších základních rysů technik využívaných v pedagogickém procesu osobnostního a sociálního rozvoje je přesná metodická struktura: Cíl (zaměření techniky) $\rightarrow$ Instrukce $\rightarrow$ Akce (průběh techniky) $\rightarrow$ Reflexe.

V našem pojetí OSR má velký prostor obor dramatická výchova, jež je založen na vzájemném jednání mezi účastníky a reálném, osobním a nikoli teoriemi zprostředkovaném poznávání fungování mezilidských vztahů v bezpečném prostředí fikce. Nastolené dramatické jednání vyžaduje vysokou aktivitu účastníků, jejich osobní zaujatost a angažovanost. Rozvíjí jejich kompetence personální, interpersonální, komunikační, pracovní i kompetence k řešení problémů.

Problematika osobnostního a sociálního rozvoje budoucích pedagogů je velmi široká a tato publikace ji nemůže plnohodnotně obsáhnout celou. Je však námětem pro možnou realizaci OSR ve vysokoškolském vzdělávání budoucích učitelů, průvodcem, jenž může adepty učitelství na jejich cestě kus doprovodit a snad jim ji i ulehčit a zpř́ijemnit. 


\section{LITERATURA}

BANDURA, A. (1977). Asocial learning theory. Englewood Cliffs: Prentice Hall.

BÖNSCH, M. (2006). Allgemeine Didaktik: ein Handbuch zur Wissenschaft vom Unterricht. Stuttgart: W. Kohlhammer.

BRATSKÁ, M. (1992). Metódy aktívného sociálného učenia a ich aplikácia. Bratislava: Univerzita Komenského.

CANFIELD, J., \& SICCONE, F. (1998). Hry pro výchovu k odpovědnosti a sebedůvěře. Praha: Portál.

DISMAN, M. (1976). Receptář dramatické výchovy. Praha: Státní pedagogické nakladatelství.

HEMOCHOVÁ, S. (2004). Hry pro dospělé. Praha: Grada.

HERMOCHOVÁ, S. (1982). Sociálně psychologický výcvik. Praha: SPN.

HERMOCHOVÁ, S. (1994). Hry pro život 1. Praha: Portál.

HERMOCHOVÁ, S. (1994). Hry pro život 2. Praha: Portál.

HICKSON, A. (1995). Dramatické a akční hry. Praha: Portál.

HRKAL, J., \& HANUŠ, R. (Eds.). (1998). Zlatý fond her II: Výběr her a programů připravených pro kursy Prázdninové školy Lipnice. Praha: Portál.

JANKOVCOVÁ, M., PRŮCHA, J., \& KOUDELA, J. (1989). Aktivizující metody $v$ pedagogické praxi středních škol. Praha: Státní pedagogické nakladatelství. 
KASÍKOVÁ, H., \& WAGNER, J. B. (1995). Dorothy Heathcote Drama as a learning medium. Pokus o recenzi s ukázkami. Tvořivá dramatika, VI (2), s. 24-28.

KOLÁR̆, J. \& LAZAROVÁ, B. (2004). O čem, jak a s kým v osobnostním rozvoji. $K$ sobě, $k$ druhým, $k$ profesi. 2(1), s. 38.

KOMÁRKOVÁ, R., SLAMĚNÍK, J., \& VÝROST J. (Eds.). (2001). Aplikovaná sociální psychologie III. Praha: Grada.

KOTRBA, T., \& LACINA, L. (2007). Praktické využití aktivizačních metod ve výuce. Brno: Barrister \& Principal.

LOKŠOVÁ, I., \& LOKŠA, J. (1999). Pozornost, motivace, relaxace a tvořivost dětí ve škole. Praha: Portál.

MACHKOVÁ, E. (1992). Metodika dramatické výchovy. Praha: Artama.

MACHKOVÁ, E. (1998). Úvod od studia dramatické výchovy. Praha: Ipos.

MACHKOVÁ, E. (2004). Jak se učí dramatická výchova: didaktika dramatické výchovy. Praha: Akademie múzických umění.

MACHKOVÁ, E. (2002). Metodika dramatické výchovy: zásobník dramatických her a improvizací. Praha: Informační a poradenské středisko pro místní kulturu.

MACHKOVÁ, E. (Ed.). (2012). Projekty dramatické výchovy pro středoškoláky. Praha: Portál.

MAŇÁK, J., \& ŠVEC, V. (2003). Výukové metody. Brno: Paido. 
MARUŠÁK, R., KRÁLOVÁ, O., \& RODRIGUEZOVÁ, V. (2008).

Dramatická výchova $v$ kurikulu současné školy: využití metod a technik. Praha: Portál.

NEUMAN, J. (1998). Dobrodružné hry a cvičení v přírodě. Praha: Portál.

NIEDENTHAL, P., \& FRANCOIS, R. (2017). Psychology of Emotion. Abingdon: Taylor \& Francis Group.

OURODA, S. (2000). Oborová didaktika. Brno: Mendelova zemědělská a lesnická univerzita.

PELÁNEK, R. (2008). Příručka instruktora zážitkových akcí. Praha: Portál.

PELIKÁN, J. (1995). Výchova jako teoretický problém. Ostrava: Amonium.

POLÍNEK, M. D. (2015). Tvořivost (nejen) jako prevence rizikového chování: expresivně-formativní potenciál základního uměleckého vzdělávání. Olomouc: Univerzita Palackého v Olomouci.

REITMAYEROVÁ, E., \& BROUMOVÁ, E. (2007). Cílená zpětná vazba. Praha: Portál.

SOJÁK, P. (2018). Osobnostní a sociální rozvoj. Praha: Grada.

SVOBODA, M. (2017). Psychosociální interakční výcvik v pedagogické praxi. Plzeň: Západočeská univerzita v Plzni.

ŠUBRTOVÁ, Z. (1984). Diskuse jako pedagogická metoda. Praha: Institut pro výchovu vedoucích pracovníků ministerstva průmyslů ČSR. 
ŠVAMBERK ŠAUEROVÁ, M. (2018). Techniky osobnostního rozvoje a duševní hygieny učitele. Praha: Grada.

ŠVEC, J. (2002). Fenomén instrukce a reflexe $v$ pedagogice osobnostně sociálního rozvoje (Diplomová práce). Praha: FF UK.

ULRYCHOVÁ, I. (2007). Drama a př́iběh: tvorba scénáře príiběhového dramatu $v$ dramatické výchově. Praha: Akademie múzických umění.

VACEK, P. (2008). Rozvoj morálního vědomí žáků. Praha: Portál.

VALENTA, J. (1999). Dramatická výchova a sociálně psychologický výcvik. Praha: ISV.

VALENTA, J. (2000). Učit se být. Kladno: Strom, Aisis.

VALENTA, J. (2006). Cesty osobnostní a sociální výchovy k žákovi. Kladno: Strom, Aisis.

VALENTA, J. (2013). Didaktika osobnostního a sociálního rozvoje. Praha: Grada.

VALENTA, J. (1999). Dramatická výchova a sociálně psychologický výcvik: (srovnání systémů). Praha: ISV.

VALENTA, J. (2008). Metody a techniky dramatické výchovy. Praha: Grada.

VALIŠOVÁ, A. (2002). Asertivita v prostředí rodiny a školy. Praha: ISV.

WAGNER, B. J. (1976). Dorothy Heathcote: Drama as a Learning Medium. Washington, D. C.: National Education Association. 
WAY, B. (2014). Rozvoj osobnosti dramatickou hrou. Praha: Sdružení pro tvořivou dramatiku.

ZAPLETAL, M. (1996). Velká encyklopedie her. Praha: Leprez.

\section{Literatura k obsahové stránce strukturovaného dramatu}

CAVENDISH, R. (1994). Dějiny magie. Praha: Odeon.

Cironis, P. (1994). Kniha černá nebo smolná královského svobodného města Rokycan z let 1573-1630. Rokycany: Státní okresní archiv.

JOHNSON, E. (1998). Sny o růžích a ohni. Praha: Odeon.

KOČí, J. (1973). Čarodějnické procesy. Praha: Horizont.

LÉVI, E. (1934). Dějiny magie. Praha: Universalia.

SALLMANN, J. M. (1994). Čarodějnice, d’áblovy nevěsty. Praha: Slovart.

SPRENGER, I., \& INSTITORIS, H. (2002). Malleus maleficarum Kladivo na čarodějnice. Praha: Nakladatelství Josefa Šimona Český klub.

ŠINDELÁŘ, B. (1986). Hon na čarodějnice. Praha: Svoboda.

VERBÍK, A., ŠTARHA, I., \& KNESL, E. (1997). Černá kniha města Velké Bíteše. Brno: Blok.

ZUBER R., BEZDĚČKA J., \& BOMBERA, J. (2000). Z doby prvních letů na koštěti. Moravský Beroun: Moravská expedice. 

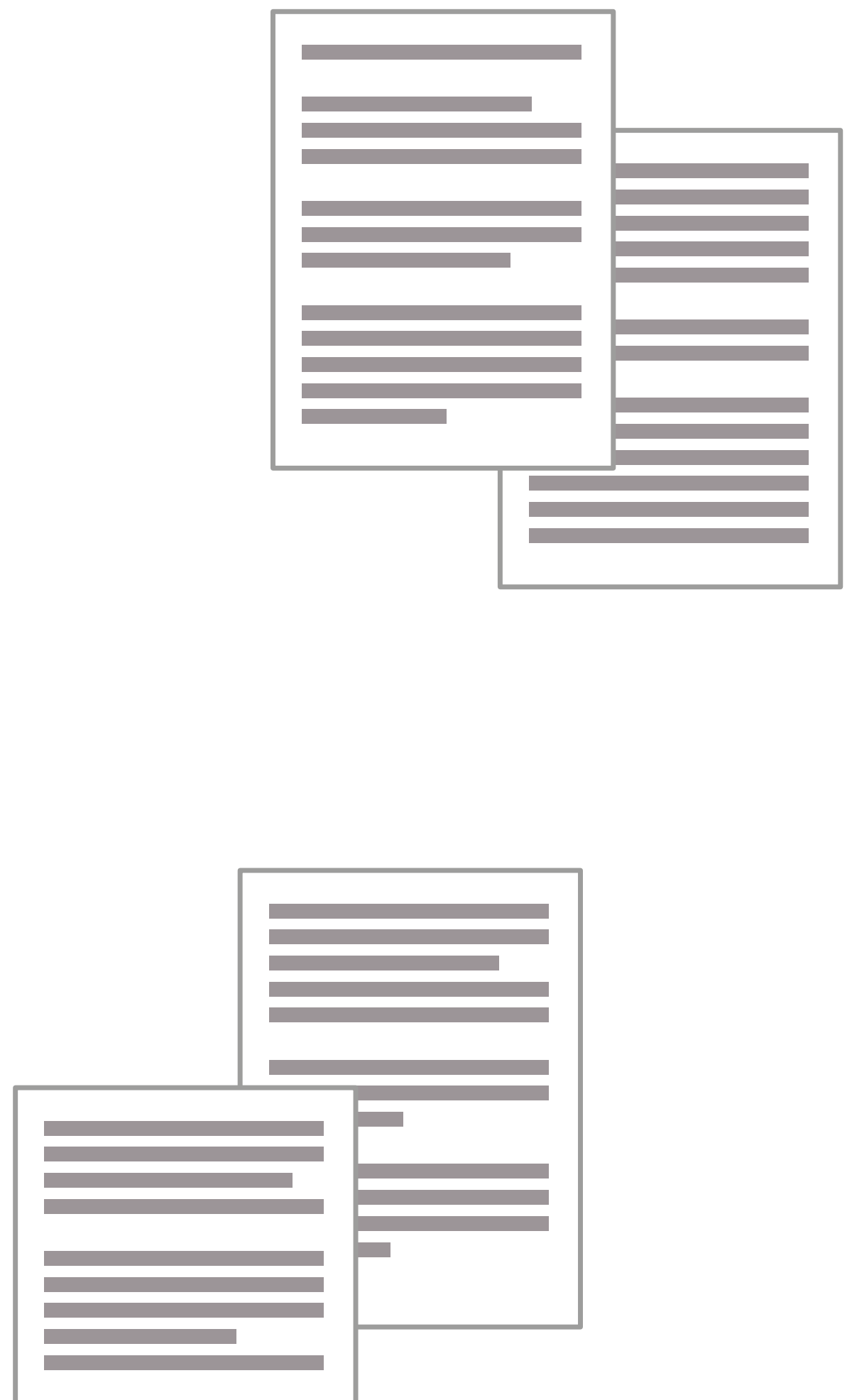


\section{OSOBNOSTNĚ SOCIÁLNÍ ROZVOJ STUDENTU゚ - BUDOUCÍCH UČITELŮ}

PhDr. Mgr. Michal Svoboda, Ph.D.

Mgr. Eva Gažáková, Ph.D.

Recenzenti:

Mgr. Margareta Garabiková Pártlová, Ph.D.

doc. Mgr. Michaela Hřivnová, Ph.D.

Grafické zpracování obálky a typografická úprava:

Lucie Slavíková

Vydala:

Západočeská univerzita v Plzni

Univerzitní 8, 30100 Plzeň

První vydání, 132 stran

Plzeň 2020

ISBN 978-80-261-0944-0

https://doi.org/10.24132/ZCU.2020.09440

〔 Autoři, Západočeská univerzita v Plzni 
